\title{
IUCN
}

World Heritage thematic study for Central Asia

Priority sites for World Heritage nomination under criteria (ix) and (x)

Hervé Lethier 


\section{About IUCN}

IUCN is a membership Union uniquely composed of both government and civil society organisations. It provides public, private and non-governmental organisations with the knowledge and tools that enable human progress, economic development and nature conservation to take place together.

Created in 1948, IUCN is now the world's largest and most diverse environmental network, harnessing the knowledge, resources and reach of more than 1,300 Member organisations and some 15,000 experts. It is a leading provider of conservation data, assessments and analysis. Its broad membership enables IUCN to fill the role of incubator and trusted repository of best practices, tools and international standards.

IUCN provides a neutral space in which diverse stakeholders including governments, NGOs, scientists, businesses, local communities, indigenous peoples' organisations and others can work together to forge and implement solutions to environmental challenges and achieve sustainable development.

Working with many partners and supporters, IUCN implements a large and diverse portfolio of conservation projects worldwide. Combining the latest science with the traditional knowledge of local communities, these projects work to reverse habitat loss, restore ecosystems and improve people's well-being.

\section{www.iucn.org \\ twitter.com/IUCN/}

\section{German Federal Agency for Nature Conservation (Bundesamt für Naturschutz $-\mathrm{BfN}$ )}

The German Federal Agency for Nature Conservation (Bundesamt für Naturschutz - BfN) is the German government's scientific authority responsible for national and international nature conservation. BfN is one of the government's departmental research agencies and reports to the Federal Ministry for the Environment, Nature Conservation and Nuclear Safety (BMU). The Agency provides the Ministry with professional and scientific assistance in all nature conservation and landscape management issues and in international cooperation activities. BfN furthers its objectives by carrying out related scientific research and is also in charge of a number of funding programmes.

\section{www.bfn.de \\ twitter.com/bfn_de}

\section{Michael Succow Foundation}

The Michael Succow Foundation was founded in 1999 as an early conservation foundation under civil law in the new federal states of re-united Germany. The operational foundation is a non-profit organization working both nationally and internationally. A strong focus of foundation's work lies on supporting habitat conservation at the landscape level through protected areas or sites of integrated conservation and use, such as national parks and UNESCO biosphere reserves. It has gained substantial expertise in supporting UNESCO World Heritage nomination processes worldwide.

\section{www.succow-stiftung.de twitter.com/succow_stiftung/}




\section{World Heritage thematic study for Central Asia}

Priority sites for World Heritage nomination under criteria (ix) and (x)

Hervé Lethier 
The designation of geographical entities in this publication, and the presentation of the material, do not imply the expression of any opinion whatsoever on the part of IUCN concerning the legal status of any country, territory, or area, or of its authorities, or concerning the delimitation of its frontiers or boundaries.

The views expressed in this publication do not necessarily reflect those of IUCN.

Published by: $\quad$ IUCN, Gland, Switzerland and IUCN Regional Office for Eastern Europe and Central ASIA (ECARO), Belgrade, Serbia

Copyright: $\quad$ (c) 2020 IUCN, International Union for Conservation of Nature and Natural Resources

Reproduction of this publication for educational or other non-commercial purposes is authorised without prior written permission from the copyright holder provided the source is fully acknowledged.

Reproduction of this publication for resale or other commercial purposes is prohibited without prior written permission of the copyright holder.

Citation: $\quad$ Lethier, H. (2020). World Heritage thematic study for Central Asia. Priority sites for World Heritage nomination under criteria (ix) and (X). Gland, Switzerland and Belgrade, Serbia: IUCN and IUCN ECARO. xii+103pp

ISBN:

978-2-8317-2030-2 (PDF)

978-2-8317-2031-9 (print)

DOI:

https://doi.org/10.2305/IUCN.CH.2020.02.en

Cover photo Southern Ustyrt Kaplankyr, Kazakhstan (c) Mark Pestov

Layout by: $\quad$ Imre Sebestyén, jr. / Unit Graphics

Printed by: $\quad$ Unit Graphics

Available from: $\quad$ IUCN Regional Office for Eastern Europe and Central ASIA (ECARO)

Dr Ivana Ribara 91

11070 Belgrade, Serbia

Tel +381112272 411

ecaro@iucn.org

www.iucn.org/resources/publications

The text of this book is printed on paper made from wood fibre from well-managed forests certified in accordance with the rules of the Forest Stewardship Council (FSC). 


\section{Contents}

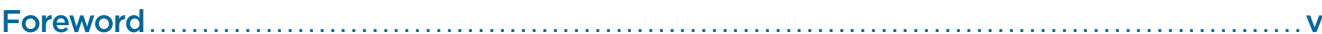

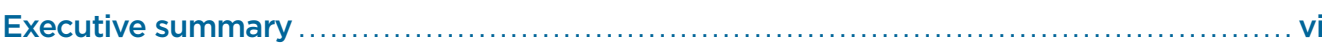

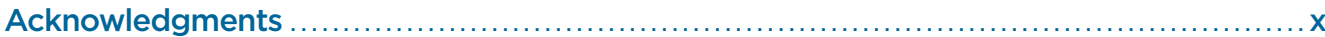

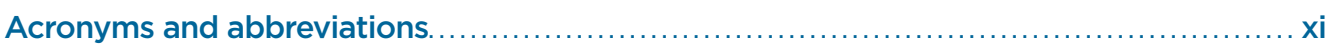

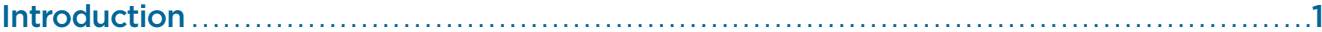

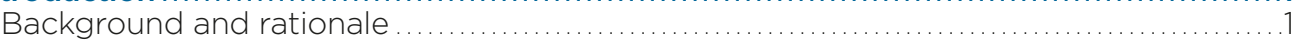

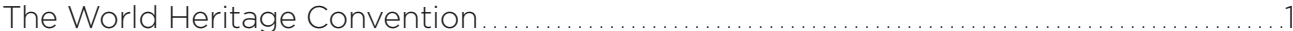

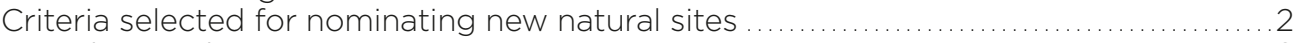

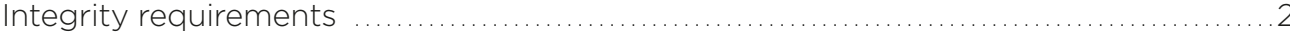

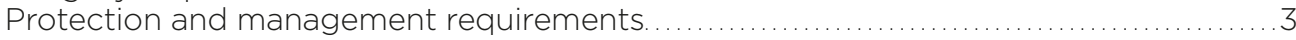

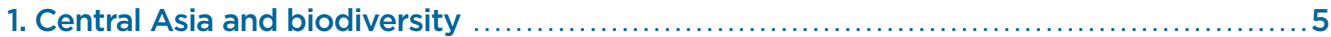

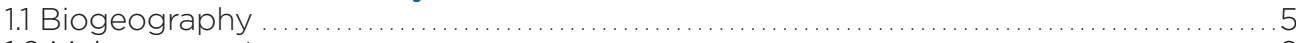

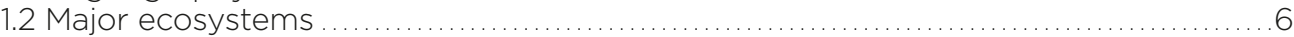

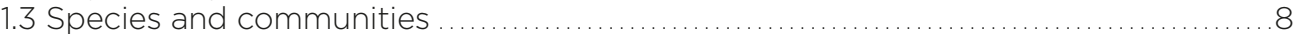

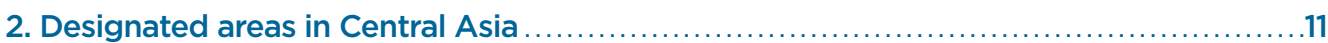

2.1 Protected Areas network ....................................................... 11

2.2 Internationally Recognised Areas ................................................ 12

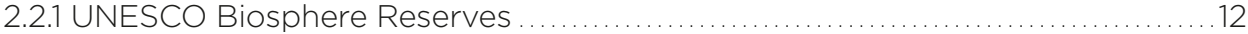

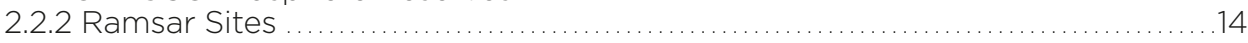

3. Natural World Heritage sites in Central Asia .........................................17

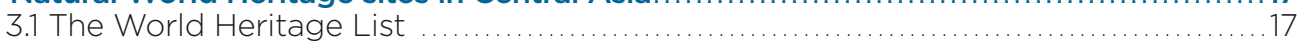

3.2 Tentative Lists

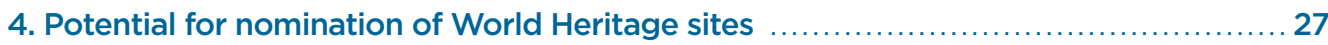

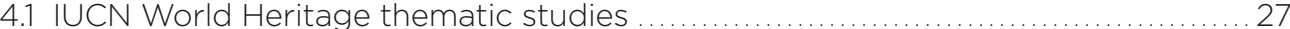

4.1 .1 Regional overview for Central Asia................................................. 27

4.1.2 Potential Priorities for recognition of desert landscapes and

geomorphological sites on the World Heritage List ........................... 30

4.1 .3 World Heritage, wilderness and large landscapes.............................. 30

4.2 Other studies............................................

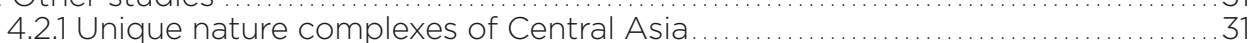

4.2.2 Mountains of Central Asia biodiversity hotspot ............................. 34

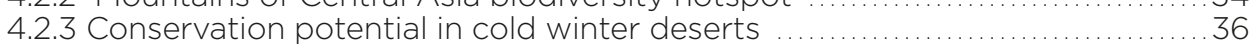

4.2.4 Wetlands

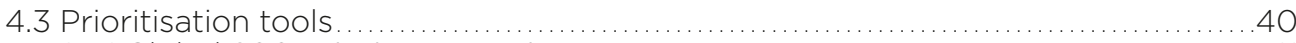

4.3.1 Global 200 Priority Ecoregions ............................................... 41

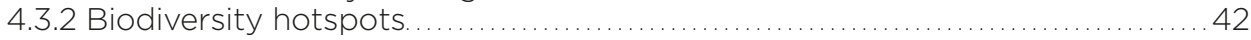

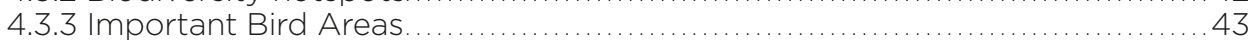

4.3.4 Key Biodiversity Areas........................................................... 44

4.3.5 The most irreplaceable protected areas for mammal, bird and amphibian conservation ................................................ 45

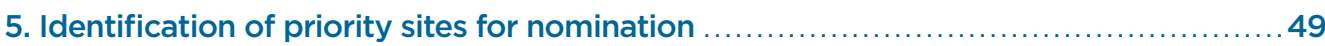

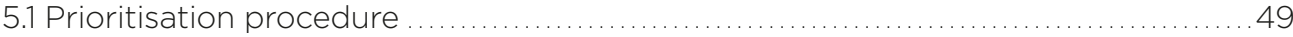

5.2 Potential candidate sites recommended............................................. 50

5.2.1 Extension of sites inscribed on the World Heritage List.......................... 51

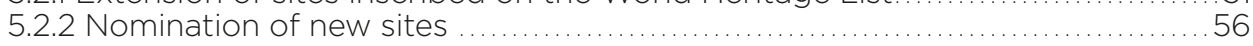

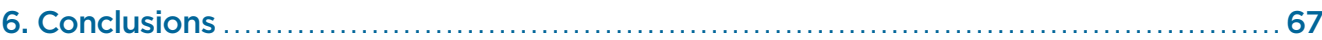

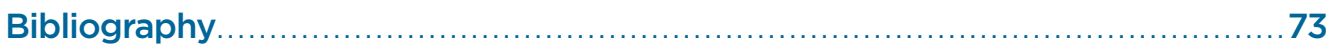

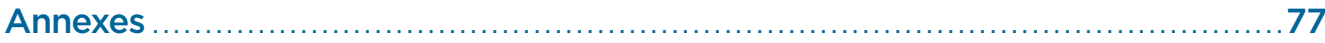

Annex 1. Participants to the workshops and consulted experts...................... 77

Annex 2. Terrestrial threatened species (fauna) ................................... 80

Annex 3. Terrestrial threatened species (flora) ....................................... 83

Annex 4. Important Bird Areas in Central Asia .......................................... 85

Annex 5. Areas having potential for Key Biodiversity Areas .............................. 90

Annex 6. Areas having potential for Key Biodiversity Areas in the mountain
hotspot of Central Asia and not overlapping with existing protected areas........... 97

Annex 7. Tentative list submission format ............................................... 102

Annex 8. Tentative list submission format for transnational and transboundary

future nomination 


\section{LIST OF BOXES, TABLES AND FIGURES}

\section{Boxes}

Box 1. The Ramsar Sites criteria.

\section{Tables}

Table 1. Udvardy Biogeographical Provinces in Central Asia and WH sites .................... 6

Table 2. Threatened species in Central Asia .............................................. 9

Table 3. Protected Areas network in Central Asia................................................... 11

Table 4. UNESCO BR network in Central Asia ............................................. 13

Table 5. Ramsar Sites in Central Asia .......................................................... 14

Table 6. Sites inscribed on the World Heritage List .......................................... 18

Table 7. Sites included on the Central Asian countries' TL................................. 19

Table 8. Preliminary review of the sites included in Tentative Lists. . . . . . . . . . . . . . . . . . . 21

Table 9. Sites suggested as priority natural sites in Central Asia . . . . . . . . . . . . . . . . . . . 27

Table 10. Sites suggested as mixed sites in Central Asia .................................... 28

Table 11. Sites selected as potential natural and mixed sites in Central Asia ...................... 30

Table 12. Natural complexes prioritised as having potential for nomination under biodiversity criteria

Table 13. Priority sites for CEPF investment not inscribed in the WH List ...................... 35

Table 14. Potential KBAs in the Mountains of Central Asia Hotspot .............................. 35

Table 15. Eco-corridor and selected landscapes characteristics for CEPF investments in the Mountains of Central Asia Hotspot ................................................. 36

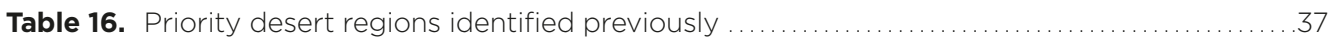

Table 17. Natural WH sites currently listed in the four Global 200 Priority Ecoregions overlapping Central Asia ................................................. 41

Table 18. IBAs in Central Asia............................................................ 43

Table 19. Most irreplaceable protected areas in Central Asia . ................................ 46

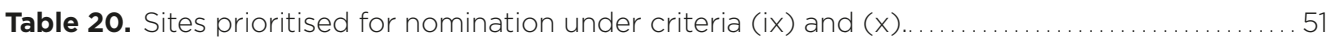

\section{Figures}

Figure 1. Key ecosystem communities in Central Asia............................................ 8

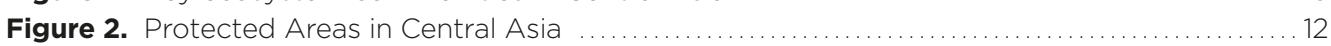

Figure 3. International designations of areas in Central Asia ............................... 13

Figure 4. Percentage of global-scale wilderness currently protected in natural and mixed World Heritage sites (NWHS), for each of the 14 biomes

Figure 5. Priority regions in terms of habitat diversity overlapping at least three different desert types within a reasonable sized territory

Figure 6. The four terrestrial Global 200 Priority Ecoregions overlapping Central Asia ........... 41

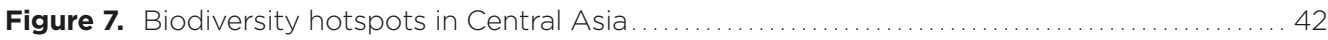

Figure 8. Important Bird Areas in Central Asia ................................................... 44

Figure 9. Key Biodiversity Areas in Central Asi ............................................. 45

Figure 10. Priority sites for World Heritage nomination in Central Asia ........................... 50 


\section{FOREWORD}

The 1972 World Heritage Convention aspires to protect, present and transmit our planet's most exceptional cultural and natural heritage to future generations. The Convention is one of the most important global conservation instruments and has been signed by almost all nations of the world, including the five countries of Central Asia (Kazakhstan, Kyrgyzstan, Tajikistan, Turkmenistan and Uzbekistan). Despite the adoption of the Convention amongst all of the countries in the region, and the region's high biodiversity values, natural sites from Central Asia remain under-represented on the World Heritage List. As such, identifying areas within this region that display good potential to fulfil the requirements for inscription as natural World Heritage sites, especially those which may qualify under biodiversity criteria ((ix) and $(x)$ ), has been outlined as a priority by the World Heritage Committee.

As the world's largest environmental network and as the official Advisory Body on natural sites to the World Heritage Convention, IUCN is in a unique position to support the State Parties to the Convention in the identification of potential new World Heritage sites and therefore contribute to a more credible, balanced and representative World Heritage List. The independent desk assessments presented in this report are based on information and data mobilized through the State Parties in Central Asia, IUCN's World Heritage Programme and its network of experts, the IUCN World Commission on Protected Areas (WCPA) and the Species Survival Commission (SSC). International and national experts, specialists and NGOs who participated in this process, and reviewers, are gratefully acknowledged for their patient and committed efforts.

This study is not intended to be prescriptive or definitive and should be viewed as a first step towards identifying and selecting those sites with potential for nomination as natural World Heritage sites in Central Asia; future nominations will require more indepth analysis than contained here. Should any of these sites be advanced to nomination, IUCN's full, rigorous and independent evaluation processes will apply. It is hoped that this study will raise awareness of the importance of natural World Heritage sites in the region and beyond. We hope that it will support ongoing efforts by the State Parties to conserve some of the world's most important terrestrial biodiversity in Central Asia, by identifying natural areas and sites that could be considered for nomination under biodiversity criteria.

IUCN looks forward to supporting the State Parties and expert community in Central Asia in realizing the potential of the World Heritage Convention and will be pleased to provide further advice and guidance concerning future nominations.

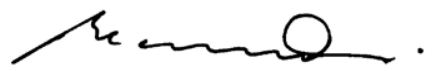

Peter Shadie, Director IUCN World Heritage Programme

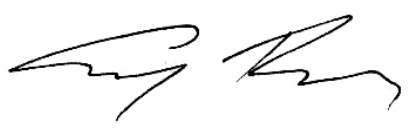

Boris Erg, Director

IUCN Regional Office for Eastern Europe and Central Asia 


\section{Executive summary}

The World Heritage thematic study for Central Asia has been produced as a contribution to supporting the implementation of the World Heritage Convention in Central Asia. It provides a response to a Decision of the World Heritage Committee (Decision WHC 39 COM 8B.4)' requesting IUCN to update the 2005 World Heritage thematic study for Central Asia (Magin, 2005) ${ }^{2}$ in order to identify outstanding areas with potential for future nomination to the WH List with primary focus on criteria (ix) and ( $x$ ) at the regional scale. The approach applied in this study, focusing on criteria (ix) and (x), follows that from the 2013 study on terrestrial biodiversity and the World Heritage List (Bertzky et al., 2013). Criteria (ix) and $(x)$ are clearly the primary ones for recognition of extant biodiversity values, and they have been applied to a wide range of biodiversity features, including ecosystems, species, and ecological and/or biological processes.

The preparation process for this report followed three main phases:

- desk assessment and overview of sites having potential to meet the requirements of the World Heritage Convention for inscription on the WH List (January-June 2018);

- three regional consultations on priority sites for potential WH nomination (June, October and November 2018), involving 40-50 international and local experts and specialists;

- preparation of the WH Thematic Study in consultation with the relevant State Parties, scientists and expert organizations and individuals (October 2018-March 2019).

It is important to stress that the findings and recommendations presented in this report stem from the desk review that was to a large extent limited to the literature in English, internet sources based on available data, and consultations with national and international experts. In some cases, the data may not be fully up to date or reflect the reality on the ground. Significant efforts have been made to validate the data with national and international experts and field specialists who have contributed to the online consultation and participated in discussions in workshops and engaged in further exchanges with IUCN and the lead author during the drafting process. Therefore, the findings of the study should be interpreted as indicative and are subject to change upon further updates and consultation.

As a result, nine sites and areas have been identified as having high potential for nomination under biodiversity criteria (ix) and/or (x), in combination with other WH natural criteria (vii) and (viii).

The fact that some of these identified priority areas are currently not under any official protection regime does not mean that they cannot be included on TLs, if those areas and sites have high potential for nomination. This potential for nomination should be used by the State Parties to improve their current level of protection and management. In fact, World Heritage sites are meant to be the most outstanding examples of long-term conservation of natural and cultural values through effective protection regime and management.

Although this study is an initial assessment, most areas and sites recommended here have appeared repeatedly as being of particular interest for biodiversity conservation during the work process, whether through literature analysis or in discussions with experts and specialists. They have been identified based on an initial screening of their value, level of integrity, exposure to potential threats, existing legal protection regime and effective 


\begin{tabular}{|c|c|c|}
\hline \multirow{3}{*}{$\begin{array}{l}\text { Sites already } \\
\text { inscribed in the } \\
\text { WH List that could } \\
\text { be extended }\end{array}$} & Golden Mountains of Altai & $\begin{array}{l}\text { Russian Federation (potential } \\
\text { for extension in Kazakhstan) }\end{array}$ \\
\hline & $\begin{array}{l}\text { Saryarka - Steppe and Lakes } \\
\text { of Northern Kazakhstan }\end{array}$ & Kazakhstan \\
\hline & Western Tien-Shan & $\begin{array}{l}\text { Kazakhstan, Kyrgyzstan, } \\
\text { Uzbekistan }\end{array}$ \\
\hline \multirow{4}{*}{$\begin{array}{l}\text { Sites currently } \\
\text { included on } \\
\text { Tentative Lists }\end{array}$} & Tigrovaya Balka & Tajikistan \\
\hline & $\begin{array}{l}\text { Badhyz and Kopetdag } \\
\text { Mountains }\end{array}$ & Turkmenistan \\
\hline & Northern Tien-Shan & Kazakhstan \\
\hline & $\begin{array}{l}\text { Repetek State Biosphere } \\
\text { Reserve }\end{array}$ & $\begin{array}{l}\text { Turkmenistan (potential } \\
\text { for serial nomination in } \\
\text { Kazakhstan and Uzbekistan) }\end{array}$ \\
\hline \multirow[t]{2}{*}{$\begin{array}{l}\text { Areas not included } \\
\text { on Tentative Lists }\end{array}$} & Southern Ustyurt Plateau & $\begin{array}{l}\text { Kazakhstan, Turkmenistan } \\
\text { and Uzbekistan }\end{array}$ \\
\hline & $\begin{array}{l}\text { Cold Winter Deserts of } \\
\text { Central Asia }\end{array}$ & Transnational \\
\hline
\end{tabular}

adequate management, by cross-referencing the available information and data. It should be stressed that, having identified these potential candidate WH sites, more in-depth analysis at the site level will be critical to fully understand their potential to meet the requirements of the Operational Guidelines. Several recommended areas and sites are serial and/or transnational or transboundary and will require coordination between the State Parties in order to develop a nomination.

In all cases, any areas, component parts or specific boundaries will require further detail and more precision in the process of preparation of a nomination.

Finally, it is worth noting that local communities inhabit some very remote areas prioritized here, at least seasonally and sometimes throughout the year. Unfortunately, it was beyond the scope of this survey to address the cultural aspect and indigenous matters, but it is fundamental to underline that rights issues have to be appropriately considered during every nomination process. The State Parties and all experts and organizations associated in such a process are strongly advised to address this central topic and refer to the existing "good practices" concerning human rights and World Heritage when starting their work. ${ }^{3}$

\section{Additional recommendations}

The recommendations below reflect the current level of knowledge that should be strengthened in the future, to ensure that the identified areas and sites are well supported with the necessary data and empirical evidence to address the requirements of the Operational Guidelines. In that sense, these recommendations should be interpreted as a starting point for further technical analysis. These recommendations are intended to fill the major administrative and technical gaps and difficulties observed during the development of the study and consultations with national authorities and experts. 


\section{Create and/or update current Tentative Lists}

State Parties are encouraged and invited to re-examine or review their Tentative Lists (TLs), with a focus on criteria (ix) and (x), without excluding other natural criteria (vii and/or viii). The findings of this Thematic Study should be taken into account by the State Parties while reviewing their TLs.

All TLs should be updated after a consultation process to ensure that the sites included in the lists are harmonized and have the highest potential for nomination at the regional level, based on a solid overall comparative analysis, which was not possible to conduct during this process. States Parties are invited to take into account the findings and recommendations presented here into these processes.

A comparative analysis specific to each site should also provide useful information on its value, main attributes and features for potential nomination under either criterion. ${ }^{4}$ The purpose of such an analysis is to ascertain whether there is a scope for the inclusion of the site in the list or not, and to demonstrate that there is no other natural property with similar values inscribed on a TL or with higher value that might be nominated in the future.

\section{Improve the protection regime of areas and ecological corridors with the highest values for natural heritage}

Central Asia is a global biodiversity hotspot, home to numerous iconic and threatened species and key natural habitats and ecosystems. They include significant migratory routes and flyways, and important breeding areas.

In this context, the identification of areas of sufficient size and establishment of adequate buffer zones will be of highest importance for nomination under either biodiversity criterion, to enhance and maintain the natural processes and preserve the state of conservation of those species. Thus, ecological corridors and key habitats for wildlife and migration need to be clearly identified and delimited for prioritisation. This work seeks inputs from relevant conservation processes and conventions. ${ }^{5}$

Efforts should be made not only to extend existing protected areas but also to set up new ones, in order to enhance ecological and habitat connectivity and improve protection of key flora and fauna areas, thereby allowing the nomination of more integrated landscape configurations.

\section{Consider a range of international designation mechanisms to recognize areas of global importance}

Areas of international importance and sites recognised under other international legal instruments or through knowledge-based tools (international/regional inventories of areas important for biodiversity conservation can help formulate Statements of Outstanding Universal Value (OUV) for existing and future WH sites.

State Parties should consider existing designations and inventories as opportunities to identify and select areas and sites having the highest potential for nomination. 


\section{Foster transnational cooperation and transboundary sites to support ecological functionality that guarantees the maintenance of natural processes}

There is strong potential for identifying transboundary and transnational sites. Some protected areas from the region may have difficulty in meeting the WH requirements if only areas within one country are included. Therefore, it would be helpful to foster cooperation and agree on a common regional strategic approach between State Parties for the identification and delimitation of transnational and/or transboundary sites.

Based on the recommendations of this study, the State Parties are invited to build a common vision of $\mathrm{WH}$ in the region that facilitates nomination of natural sites having the highest potential under natural criteria, especially in cold winter desert ecosystems that are currently poorly represented on the WH List.

\section{Develop continuous dialogue among stakeholders}

The need to develop dialogue among stakeholders at all levels, e.g. local, national, regiona and international, emerged as one of the major conclusions of the consultations conducted during this study. This dialogue should be strengthened in the future, based on more frequent and regular exchanges and stronger cooperation between stakeholders (e.g. State Parties, scientists, NGOs, local communities).

International organisations should stimulate this dialogue, facilitate the exchange of good practices, and contribute to the identification of solutions to common problems and means to facilitate the nomination processes.

\section{Improve enforcement and compatibility between local, national and international regulatory frameworks} The consultations raised awareness of the difficulties in the practical implementation of
international laws and agreements at the national and local levels, related to the lack of
compatibility among diverse regulations.

Efforts should be made by State Parties to improve this compatibility in the future and to adapt their national legal and regulatory frameworks ensuing from international commitments on biodiversity conventions.

\section{Conduct training sessions and activities on nomination preparation}

\footnotetext{
Consultation workshops confirmed that difficulties observed during the IUCN evaluation process could be associated with a lack of capacity for WH nomination. In order to overcome these shortcomings, operational guidance should be developed that focuses on specific phases of the nomination process, such as preparation of the comparative analysis, nomination under criteria (ix), and serial and/or transnational or transboundary sites.
}

Based on existing good practices and guidance documentation, specific training and tutoring activities should be organised during the upstream process of site nomination for public service officers and local specialists, with support from IUCN and other relevant international organizations. 


\section{ACKNOWLEDGMENTS}

We are very grateful for the invaluable contribution of the State Parties of Kazakhstan, Kyrgyzstan, Tajikistan, Turkmenistan and Uzbekistan, National Commissions for UNESCO, and all organisations, national and international experts in the development of this thematic study. Its development would not be possible without input received from participants in three workshops held in: Bishkek, Kyrgyzstan (19-20 June 2018), Asghabat, Turkmenistan (11-12 October 2018), and Tashkent, Uzbekistan (28-29 November 2018) (Annex 1).

Maps were prepared by the Michael Succow Foundation (MSF) in the frame of the Central Asian Desert Initiative (CADI) as part of the International Climate Initiative (IKI). The Federal Ministry for the Environment, Nature Conservation and Nuclear Safety supports this initiative on the basis of a decision adopted by the German Bundestag.

This publication has been made possible through a project World Heritage in Central Asia, funded by the German Federal Environment Ministry's Advisory Assistance Programme (AAP) for environmental protection in the countries of Central and Eastern Europe, the Caucasus and Central Asia and other countries neighbouring the European Union. It was supervised by the Federal Agency for Nature Conservation (BfN) and the German Environment Agency (UBA).

Finally, we sincerely thank reviewers, proofreaders and designers for their work on finalisation of the study.

The content of this report is solely the responsibility of the author and should not be interpreted as reflecting the views of any of the individuals and organisations that contributed to the report or any of its elements. 


\section{ACRONYMS AND ABBREVIATIONS}

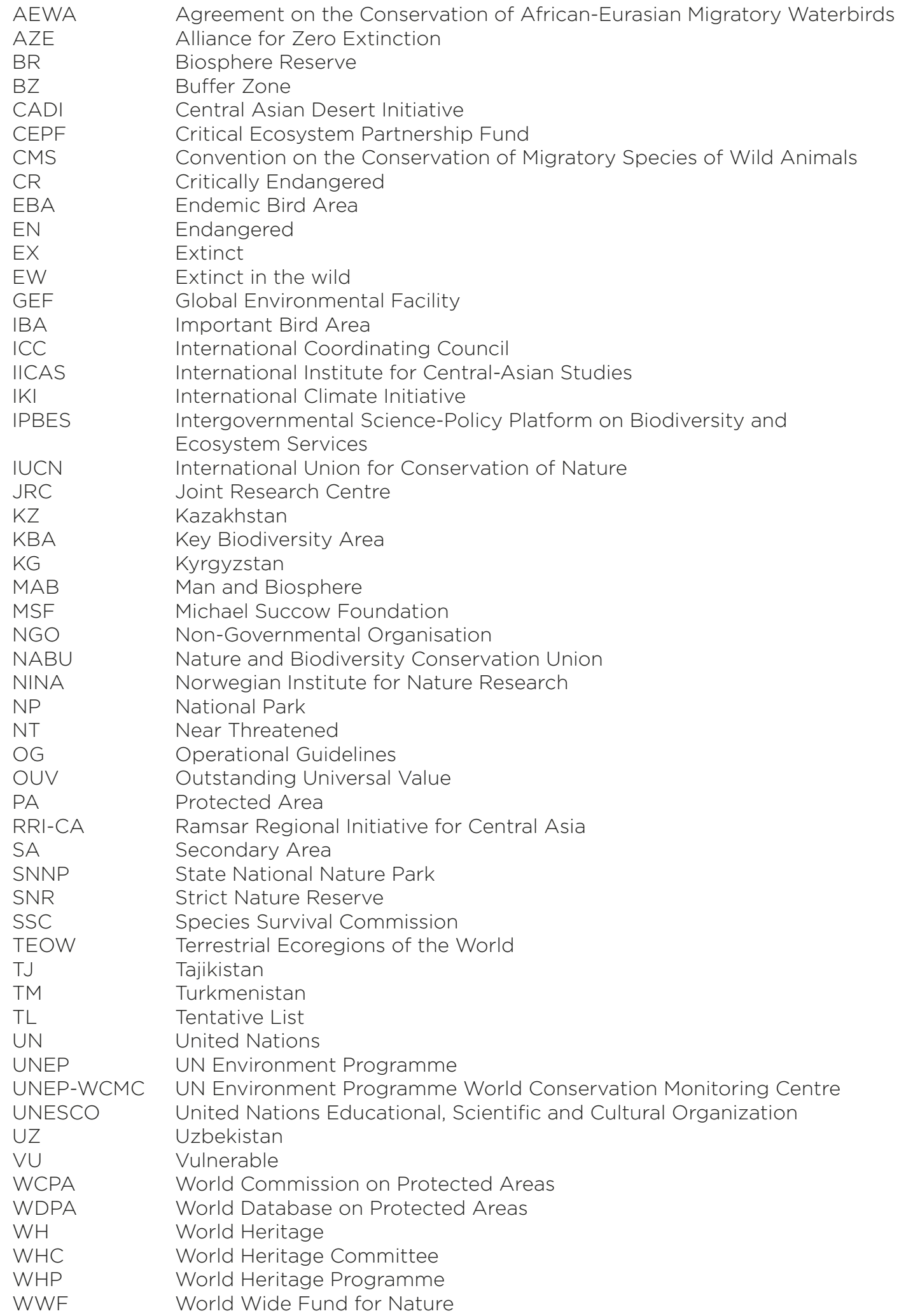




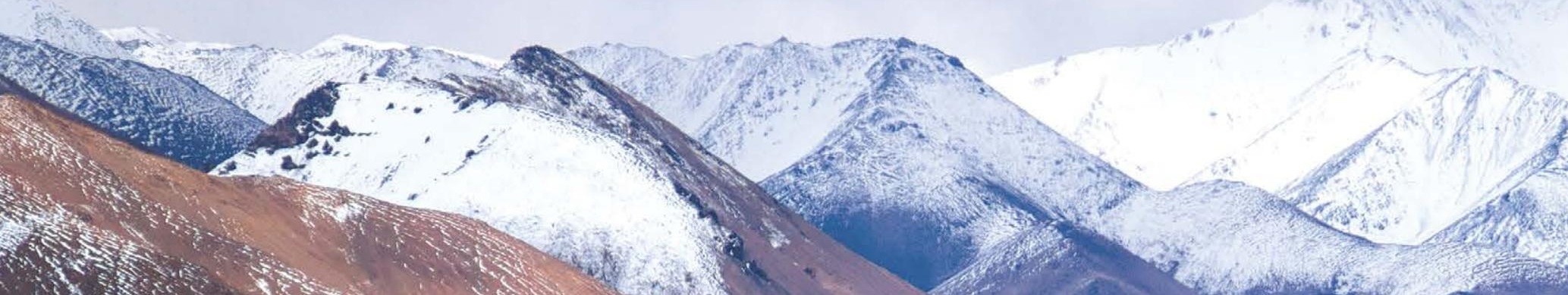

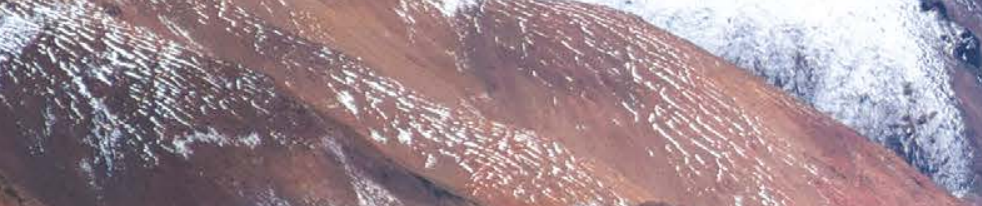

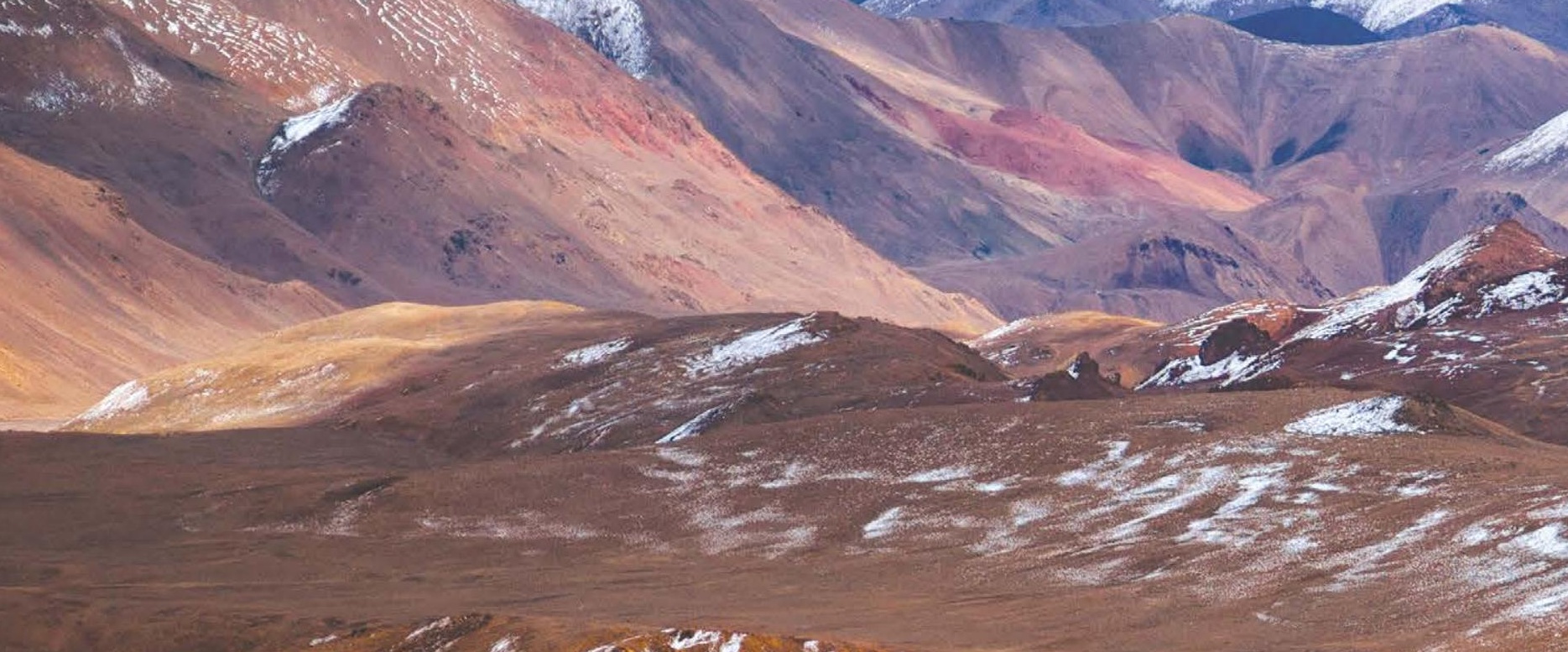

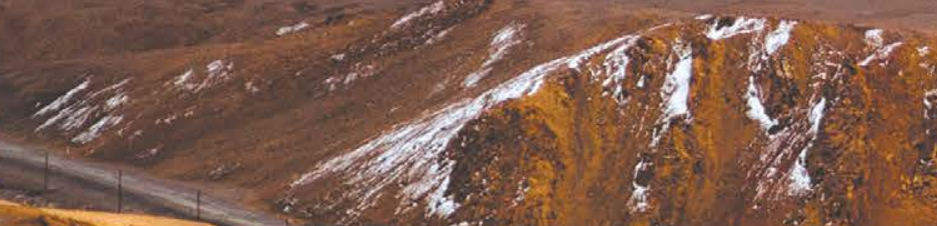

\section{4}

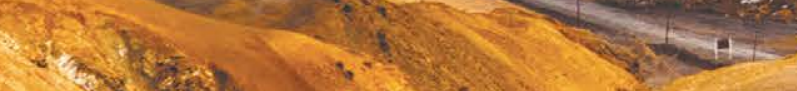

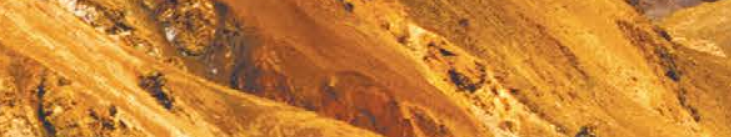

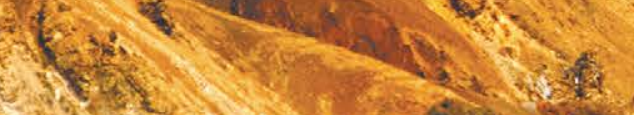

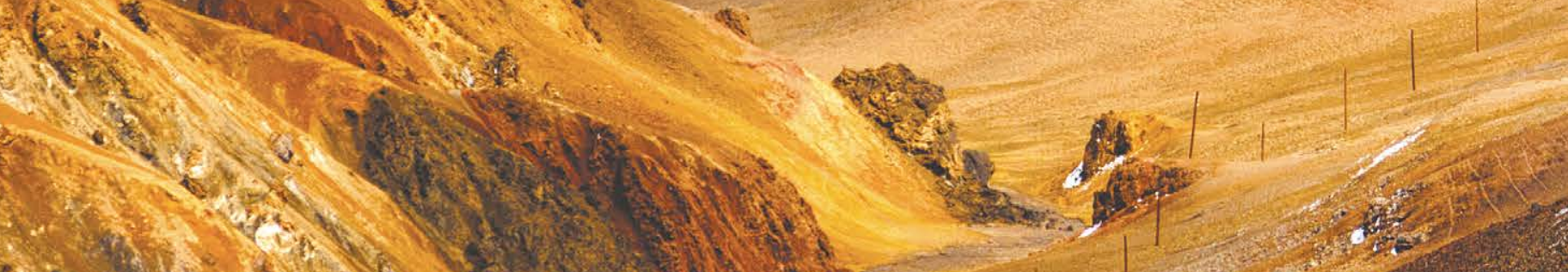
(3)

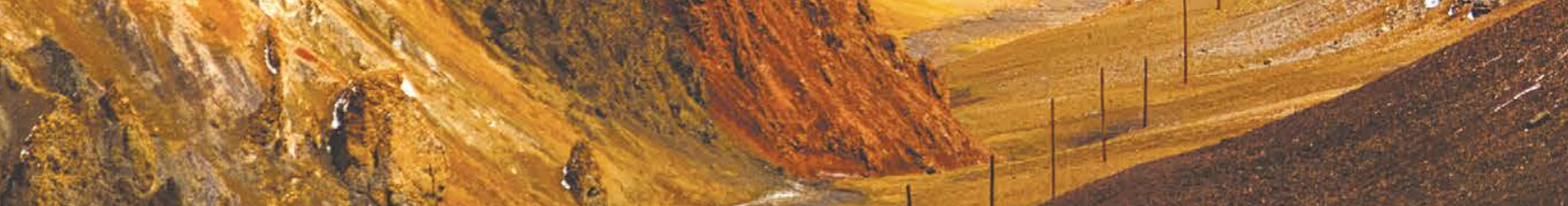

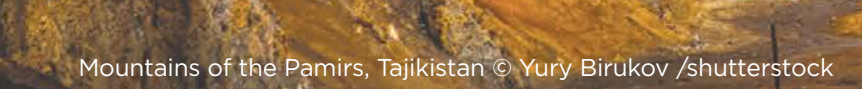




\section{Introduction}

\section{Background and rationale}

Based on a global strategy for a balanced and representative WH List adopted by the WHC in 1994 (Decision WHC 28 COM 13.1), ${ }^{6}$ IUCN, in collaboration with the WH Centre, UN Environment Programme World Conservation Monitoring Centre (UNEP-WCMC) ${ }^{7}$ and the Ramsar Convention, have produced a series of thematic studies providing overview assessments of major themes relating to natural sites. Thematic studies are aimed at providing guidance for the implementation of the World Heritage Convention, identifying gaps in the WH List and advising State Parties and interested parties on World Heritage nomination and management.

The first WH thematic study for Central Asia was published in 2005, identifying a series of sites with high potential for nomination under criteria (viii), (ix) and (X) (Magin, 2005). This new study builds on the 2005 study, with a specific focus on the terrestrial realm and on criteria (ix) and ( $x$ ) in the five countries of the region, i.e. Kazakhstan, Kyrgyzstan, Tajikistan, Turkmenistan, and Uzbekistan. Focus on criteria (ix) and ( $x$ ) follows the approach taken in the study Terrestrial Biodiversity and the World Heritage List: Identifying broad gaps and potential candidate sites for inclusion in the natural World Heritage network (IUCN and UNEP-WCMC, 2013).

This study is based on a desk review and extensive consultation with national and international organisations and experts, and has been finalized in close consultation with key stakeholders during the latter half of 2018 and first quarter of 2019. Consultations were organised to ensure full transparency and validate information collated during the assessment. The participants included national experts from the five Central Asian countries, encompassing both governmental and nongovernmental organisations, as well as international experts.

\section{The World Heritage Convention}

The World Heritage Convention identifies, protects and promotes cultural and natural heritage of OUV around the world (UNESCO, 1972). Sites with OUV are defined in the Convention's Operational Guidelines ( $\mathrm{OG}$ ) as areas "so exceptional as to transcend national boundaries and to be of common importance for present and future generations of all humanity" (UNESCO, 2017). ${ }^{8}$

The OG identifies ten criteria for defining OUV, four of which address natural sites; these criteria include "ecological and biological processes" (ix) and "biodiversity" (x) that, in the present state of scientific and technical knowledge, seem to offer significant potential for nomination of sites in Central Asia.

\footnotetext{
http://whc.unesco.org/en/decisions/33/.

Previously UNEP.

https://whc.unesco.org/en/guidelines/.
} 
The OG also requires that natural WH sites demonstrate a high level of "integrity". Nominated sites are often partially degraded and their integrity may no longer meet the convention's provisions and $O G$ requirements. Therefore, the integrity of a site having potential for nomination should be assessed to know to what extent it:

- $\quad$ includes all elements necessary to express its OUV;

- is of adequate size to ensure the complete representation of the features and processes that convey the site's significance;

- $\quad$ suffers from adverse effects of development and/or neglect.

Sites must also meet the protection and management requirements, meaning they must benefit from a protection regime adequate to preserve the values for which they are nominated.

\section{Criteria selected for nominating new natural sites}

This review aims to identify a list of sites that may have OUV with respect to selected biodiversity criteria (ix) and/or (x). The 2017 Operationa/ Guidelines for the Implementation of the WH Convention provide the following explanation of criteria for the assessment of OUV: 9

- criterion (ix): be outstanding examples representing significant ongoing ecological and biological processes in the evolution and development of terrestrial, fresh water, coastal and marine ecosystems and communities of plants and animals;

- criterion ( $\mathrm{x}$ ): contain the most important and significant natural habitats for in situ conservation of biological diversity, including those containing threatened species of OUV from the point of view of science or conservation.

Furthermore, any site nominated under criterion (ix) should have sufficient size and contain the necessary elements to demonstrate the key aspects of processes that are essential for the long-term conservation of the ecosystems and the biological diversity they contain. Any site nominated under criterion $(x)$ should be the most important areas for the conservation of biological diversity. Only those areas that are the most biologically diverse and/or representative are likely to meet this criterion. The areas should contain habitats for maintaining the most diverse fauna and flora characteristics of the biogeographic province and ecosystems under consideration. A site containing wideranging species should be large enough to include the most critical habitats essential to ensure the survival of viable populations of those species. For an area containing migratory species, seasonal breeding and nesting sites and migratory routes, wherever they are located, should also be adequately protected and managed.

\section{Integrity requirements ${ }^{10}$}

Integrity measures the wholeness and intactness of natural heritage; those key words can be understood as follows:

- wholeness: all necessary attributes are within the site;

- intactness: all necessary attributes are still present - none are lost or have been significantly damaged or have decayed.

9 http://whc.unesco.org/en/guidelines/.

10 OG, sections 82-95. 
Biophysical processes and landform features of each selected site should be relatively intact, though it might not be totally pristine and might involve contact with people to some extent. Human activities, including those of traditional societies and local communities, may occur in natural areas, but these activities may be consistent with the site's OUV only where they are ecologically sustainable. This should be presented in the statement of integrity.

\section{Protection and management requirements ${ }^{11}$}

The selected sites should also benefit from an adequate protection regime that maintains and enhances the site's OUV and a management plan or system organizing properly all the site's uses and activities to ensure this value is not compromised.

Priority should be given to areas that benefit from a strong legal regime and have an effective management plan or documented system in operation, as this will greatly improve the chances of a successful nomination.

However, this should not lead to excluding sites with strong biodiversity values that may not currently be protected and/or managed adequately. In such cases, the establishment of a new protected area with an appropriate regime of protection and an effective management plan/system should be the first phase of the process. In fact, the nomination of new WH sites could be a strong driver for establishing new protected areas or expanding existing ones in areas with exceptional biodiversity values.

Protection and management of the selected sites should ensure that their OUV, including the conditions of integrity at the time of inscription, are sustained or enhanced over time:

- $\quad$ each site should have adequate long-term legislative, regulatory, institutional and/or traditional protection and management to ensure its safeguarding. This protection should include clearly delineated boundaries; legislative and regulatory measures at national and local levels should assure the protection of the site from social, economic and other pressures, or changes that might negatively impact the site's OUV;

- $\quad$ site boundaries should be drawn to incorporate all the attributes that convey the site's OUV and ensure its integrity. These boundaries should reflect the spatial requirements of habitats, species, processes or phenomena that provide the basis for the inscription of the site on the WH List; they should include sufficient areas immediately adjacent to OUV area to protect the site's heritage values from direct/ indirect effects of human pressure outside the site, and may coincide with one or more existing or proposed PAs;

- wherever necessary for the proper protection of the site, an adequate buffer zone (BZ) surrounding the nominated site should be established; this zone must have complementary legal and/or customary restrictions placed on its use and development to give an added layer of protection to the site. This should include the immediate establishment of the site, important views and other areas or attributes that are functionally important as a support to the site's OUV and its protection. The BZ should be determined in each case through appropriate mechanisms and details on the size, characteristics and authorized uses. A map indicating the precise boundaries of the site and its BZ, and a clear explanation of how the BZ protects the site, should also be provided in the nomination dossier.

$11 \quad$ OG, sections $96-98$ 


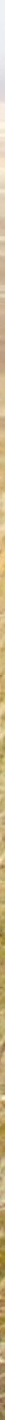

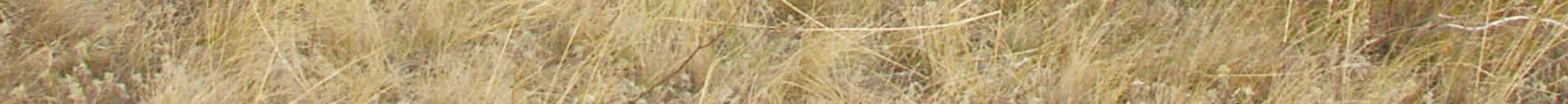

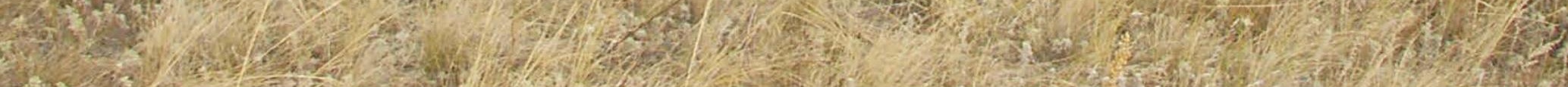

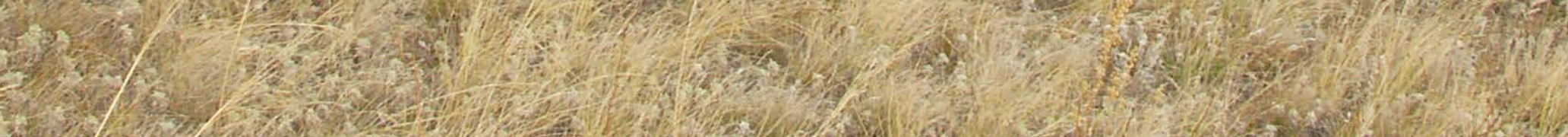

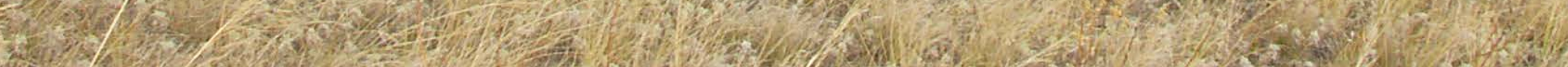

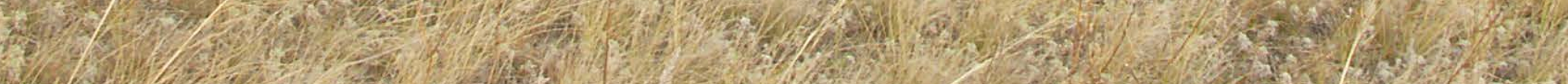

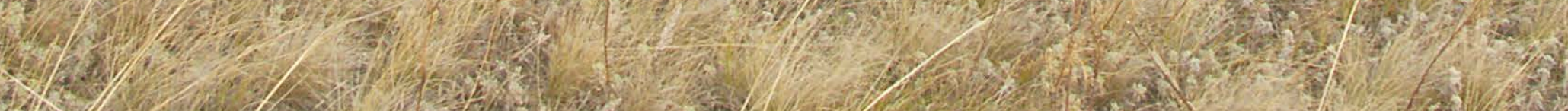

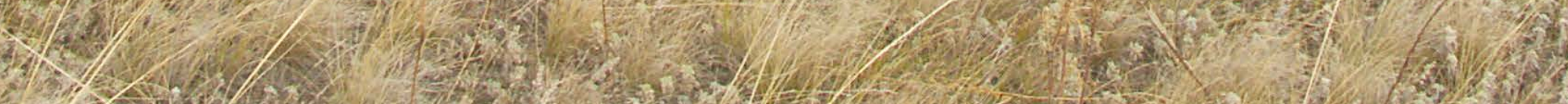

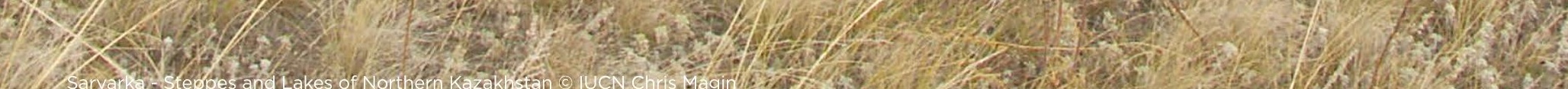

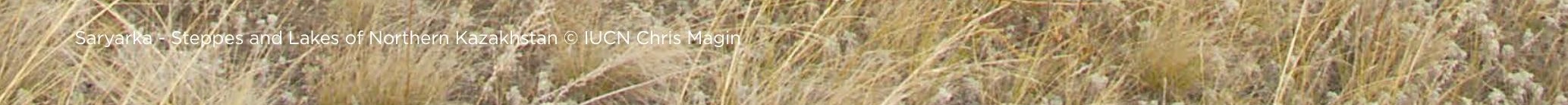

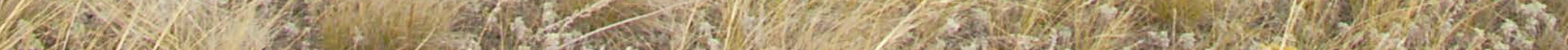




\section{Central Asia and biodiversity}

This chapter aims to provide an overview of the emblematic values of Central Asia for biodiversity, with reference to major global biogeographic classifications, and ecosystem and species datasets. This information has been compiled within the limitations of a desk study, without an in-depth analysis of Russian and native literature, or dedicated field research.

\subsection{Biogeography}

The eight biogeographic realms and 14 biomes of the world reflect the broad-scale distribution of biodiversity on Earth (Olson, 2001).

Situated in the Palearctic realm, Central Asia overlaps with three biomes:

- desert and xeric shrublands;

- flooded grasslands and savannahs;

- montane grasslands and shrublands.

According to the Udvardy classification, ${ }^{12}$ which aims to provide a satisfactory classification of the world's biotic areas for conservation purposes and which is currently used in the WH List and by IUCN to compare existing properties and nominated sites, ${ }^{13}$ Central Asia belongs to the Palearctic realm and covers part of four of the 193 terrestrial biogeographical provinces:

- Pontian steppe;

- $\quad$ Altaï highlands (which extends beyond Central Asia as defined in this report);

- Pamir/Tian-Shan highlands;

- Turanian plateau.

The Aral Sea is also a province in the region, but it is not considered a part of the terrestrial realm that is the focus of the present review. ${ }^{14}$

The first three biogeographical provinces host six WH properties, whereas the Turanian province currently hosts no sites (Table 1).

However, the Udvardy classification may not be the most relevant and accurate classification for identifying values for nomination under criteria (ix) or ( $x$ ) of the WH Convention, especially in Central Asia. This classification was used in the 2005 Central Asia Thematic Study, as it is one of the usual references used by IUCN and UNEP-WCMC to assess the comparative value of sites nominated during the IUCN internal evaluation process.

\footnotetext{
12 Udvardy, 1975

13 See below on the limits of the reference to the Udvardy classification long used by IUCN, especially in Central Asia and under criterion (ix).

14 Furthermore, the Aral Sea has almost disappeared, and over the years the term Aralkum Desert has become common in its place.
} 
Udvardy Biogeographical Province

WH sites

\begin{tabular}{|c|c|c|c|c|}
\hline Code & Name & Number & Names & Countries \\
\hline 2.21 .8 & Turanian plateau & 0 & - & - \\
\hline 2.29.11 & Pontian steppe & 1 & $\begin{array}{l}\text { Saryarka - Steppe } \\
\text { and Lakes } \\
\text { of Northern } \\
\text { Kazakhstan }\end{array}$ & Kazakhstan \\
\hline 2.35.12 & Altai Highlands & 2 & $\begin{array}{l}\text { Golden Mountains } \\
\text { of Altai* } \\
\text { Uvs Nuur Basin }\end{array}$ & $\begin{array}{l}\text { Russian Federation } \\
\text { Russian Federation } \\
\text { and Mongolia }\end{array}$ \\
\hline 2.36 .12 & Pamir/Tian-Shan Highlands & 2 & $\begin{array}{l}\text { Western Tien-Shan } \\
\text { Tajik National Park } \\
\text { (Mountains of the } \\
\text { Pamirs) }\end{array}$ & $\begin{array}{l}\text { Kazakhstan } \\
\text { Kyrgyzstan } \\
\text { Uzbekistan } \\
\text { Tajikistan }\end{array}$ \\
\hline TOTAL & & 5 & & \\
\hline
\end{tabular}

* The Altai Mountains span China, Kazakhstan, Mongolia and the Russian Federation

Table 1. As such, in due time, it may be appropriate to extend this analysis with additional reference ecosystems, and to facilitate with the prioritisation of sites having the highest potential for nomination. ${ }^{15}$

\subsection{Major ecosystems}

The Central Asian region is a vast area of some 4,000,000 km² stretching $3,000 \mathrm{~km}$ from the trans-Volga steppes in the west to the Altai Mountains in the east, and 2,000 $\mathrm{km}$ from the forest-steppe of the West Siberian plain in the north to the edge of the Iranian Plateau and the Parapamiz and Hindu Kush Mountains in the south. The largely arid ecosystems - steppes, deserts and mountains - host an exceptionally rich variety of native and endemic species. Central Asia is without question a globally important region for biodiversity. It is also characterised by ecosystems providing important environmental services for humanity (IPBES, 2018), with the following ecosystems listed in the literature as having particular value (Map 1) (GEF, 2002; WWF, 2006):

- forest-steppe: mostly located in the very northern part of the region, in Kazakhstan; these areas alternate forests - mostly deciduous - with steppe flora and host the highest species diversity of any steppe ecosystem in the world. They host many species of birds, from passerines to raptors, many of which are threatened, as well as several large ungulate, bat and rodent species;

- freshwater wetland ecosystems: both natural and artificial, these wetlands are widespread in the region and host more than 150 species of migratory birds, of which about 30 species are currently threatened according to the IUCN Red List, especially in Kazakhstan, which lies along the most significant flyway for Eurasian migratory birds. Fish and invertebrate species in Central Asia are representative of

15 See also and among others, Olson's more recent classification, which may be better adapted to the ecosystems of Central Asia. 
common and widespread palearctic assemblages with a few exceptions. ${ }^{16}$ The large lakes of the region, such as the Aral Sea, Balkhash, Issyk-Kul, Sasykkol, Alakol, Zaisan, Tengiz, and Karakul, are also known to host unique communities of plants, including many endemics. Several wetlands, such as the partly artificial lakes Sarykamysh (Turkmenistan and Uzbekistan) (Ten et al., 2012) and Aydar-Arnasay (Uzbekistan and Kazakhstan) are also of significant importance for wildlife, overlapping in many instances with many Important Bird Areas (IBA);

- $\quad$ steppe ecosystems: found on the plains and in the foothills of the region's mountains; steppe wildlife is characterised by the presence of numerous herbivorous mammals, including large ungulates, such as the saiga antelope (Saiga tatarica), and migratory birds, such as the sociable lapwing (Vanellus gregarious), demoiselle crane (Anthropoides virgo) and various species of raptors, eagles and the osprey (Pandion haliaetus), white-headed duck (Oxyura leucocephala), two species of pelicans (Pelecanus onocrotalus, Pelecanus crispus), greater flamingo (Phoenicopterus roseus), and although not common to steppe ecosystems, Eurasian curlew (Numenius arquata);

- desert ecosystems: constituting semi-deserts, winter cold deserts and sandy deserts, Central Asia's desert ecosystems are remarkable for plant communities typical for this region; they include relict species and other taxa such as Spireanthus, endemic Ferula species, Astragalus sp., and psammophytic shrub species. The fauna is characterised by a rather high degree of endemism, especially among invertebrates, mammals and reptiles. They contain the world's sole natural population of kulan (Equus hemionus), ${ }^{17}$ and significant populations of goitered gazelle (Gazella subgutturosa) and urial (Ovis orientalis), the latter occurring mostly in mountain ecosystems (see below). Local endemics such as the desert dormouse (Selevinia betpakdalaensis), saxaul sparrow (Passer ammodendri), Turkestan ground jay (Podoces panderi), Asian houbara bustard (Chlamydotis macqueenii), Sandgrouse species (Pteroptes sp. and Syrrhaptes paradoxus), Saker falcon (Falco cherrug) and Egyptian vulture (Neophron percnopterus) are also found there;

- mountain ecosystems: mountainous nival ecosystems covering elevations from 4,000 up to 7,000 $\mathrm{m}$ in the Pamir and Inner Tien-Shan Mountains, submontane plains and lower altitude mountain belts constitute Central Asia's montane ecosystems. The isolated nature of these high-altitude areas has resulted in original communities with many invertebrates, while tree species include walnut (Juglans sp), juniper (Juniperus $s p$ ), and spruce and wild fruit forests, many of which are thought to include the wild ancestors of widely cultivated fruits such as the apple. Mountainous steppes and meadows can be found in the higher mountain belt, inhabited by various species and sub-species, such as mouflon, argali (Ovis ammon), Siberian ibex (Capra sibirica) and markhor (Capra falconeri), snow leopard (Panthera uncia), Persian leopard (Panthera pardus saxicolor), Menzbier's marmot (Marmota menzbieri), Tien-Shan brown bear (Ursus arctos isabellinus), Himalyan snowcock (Tetraogallus himalayensis) and numerous rare raptor species;

- tugai forest ecosystems: found throughout the region in low elevation river valleys and on the shores of wetlands, tugai forests are characterised by communities of poplars (Populus sp.), willows (Salix sp.) and tamarix (Tamarix sp.), alternating with wet meadows and marshes. These forests are particularly suitable for Bukhara deer (Cervus elaphus yarkandensis) and, until the 1950 s was the only remaining habitat for the now extinct Caspian tiger (Panthera tigris virgata) ${ }^{18}$.

16 The Syr Darya shovelnose sturgeon (Pseudoscaphirhynchus fedtschenkoi) is potentially extinct but the Amu Darya sturgeon (Pseudoscaphirhynchus kaufmanni) is still present in the rivers.

17 Asiatic wild a ss.

18 Introduction of the Amur Tiger (Panthera tigris altaica) was assessed in the Amu Darya Delta (Uzbekistan) and the South-Balkhash-lly-Delta (Kazakhstan) regions, overlapping with existing protected areas (Jungius, 2010; also Driscoll et al., 2011, 2012; Chestin et al., 2017). 
Figure 1.

Key ecosystem communities in Central Asia (c) Michael Succow

Foundation (figure modified from Zoï, 2011)

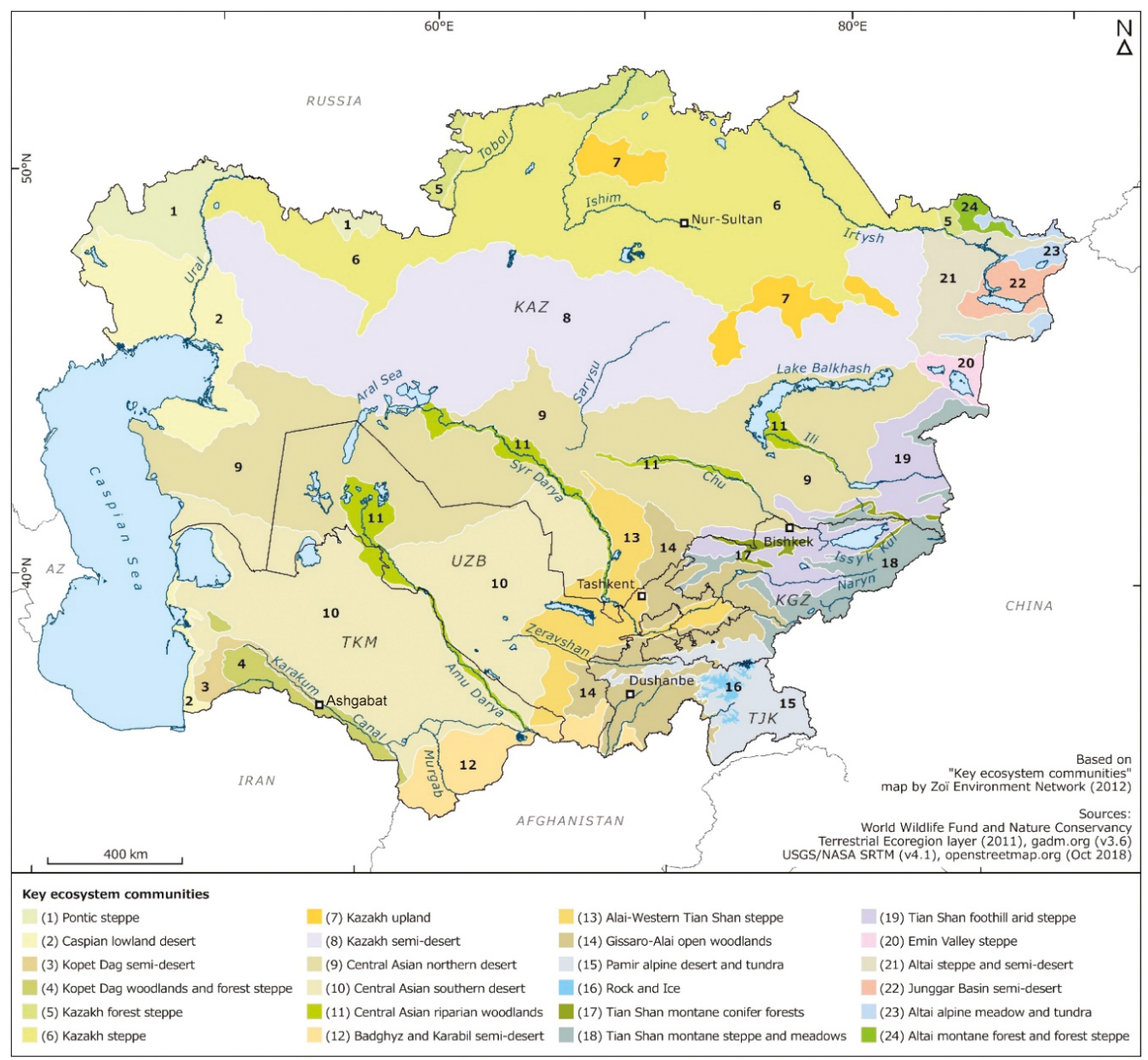

\subsection{Species and communities}

Central Asia hosts 126 threatened species, including 87 fauna species and 39 flora species, ${ }^{19}$ of which 30 species are endangered and 38 species are critically endangered (Table 2; Annexes 3 and 4). ${ }^{20}$

Flora of the region reflects the diverse biogeographical elements represented in mountain ecosystems. In total, there are 64 genera and many species of endemic flora, often with very narrow ranges, which include various species of birch, almond and juniper (Eastwood et al., 2009), as well as flowers and grasses, including 16 species of wild tulips threatened at the regional level (CEPF, 2017). Around one-third of all plant species from the whole region are endemic. ${ }^{21}$

In addition to the mountain ecosystems that are recognized as a global biodiversity hotspot (CEPF, 2017) and already well represented on the WH List, the deserts of the region host flora characteristic of various types of desert ecosystems. About 1,600 plants have been identified in the Turanian cold winter deserts, and of the roughly 350 vascular plants found in the sand deserts or cold winter deserts, some 56\% are endemic to the region (Schroeder, 1998). The diversity of flora may certainly be a strong asset for nomination of sites under criterion $(x)$ and contribute strongly to building their values.

19 Coverage of the IUCN Red List for plants is notoriously low in many geographical regions. Thus, those figures are likely minimum estimates.

20 IUCN Red List of Threatened Species website (15 April 2018) (https://www.iucnredlist.org/)

21 Floral endemism is however a controversial issue between Central Asia botanists; it will need further discussions with those experts in due time. 
Although fauna is relatively scarce because of the extreme environment, the deserts of Central Asia are home to several desert-adapted faunal species of special interest, such as the honey badger (Mellivora capensis), caracal (Caracal caracal), sand cat (Felis margarita) and marbled polecat (Vormela peregusna).

\begin{tabular}{|l|c|c|c|c|c|c|c|}
\hline Threatened species & Total & NT & VU & EN & CR & EW & EX \\
\hline Fauna & 87 & 0 & 52 & 15 & 20 & 0 & $0^{17}$ \\
\hline Flora & 39 & 0 & 6 & 15 & 18 & 0 & 0 \\
\hline TOTAL & $\mathbf{1 2 6}$ & $\mathbf{0}$ & $\mathbf{5 8}$ & $\mathbf{3 0}$ & $\mathbf{3 8}$ & $\mathbf{0}$ & $\mathbf{0}$ \\
\hline
\end{tabular}

These values form an important attribute for the biodiversity of the region. They may contribute to the representativeness of natural landscapes having high potential for future nomination under either biodiversity criterion (Schmidt, 2017), and in some cases combined with criteria (vii) and/or (viii).

Central Asia also comprises three major bird migratory flyways; 29 globally threatened and near-threatened species are considered to breed, migrate and winter in the region. ${ }^{23}$ A number of threatened migratory mammal species are listed in Appendix 1 of the Convention on Migratory Species (CMS), assessed as being in danger of extinction throughout a significant portion of their range and facing a high risk of extinction in the wild, such as Bukhara deer (Cervus elaphus yarkandensis) (Krever et al. 1998), kulan (Equus hemionus), goitered gazelle (Gazella subgutturosa) and Pallas cat (Otocolobus manul).

Among these species is the iconic saiga antelope (Saiga tatarica), ${ }^{24}$ whose conservation has been subject to significant international interest and effort. The catastrophic decline of the species over the past century has been attributed to poaching for the horn trade and infectious diseases triggered by environmental changes, while major threats for this species also include different types of linear infrastucture such as fences, railways and roads that fragment their functional habitat and impede migratory movements. Thanks to efficient conservation efforts, the Central Asian population has recovered from 30,000 in the mid-1990s to 300,000 individuals in early 2015. Unfortunately, a mass mortality event in May 2015, caused by the bacteria Pasteurella multocida, affected the main population of Betpak Dala, Kazakhstan, reducing the total Central Asian population to 100,000 animals. Since then, the population has shown encouraging signs of recovery.

The large mammal migrations of Central Asia are certainly one of the key environmental processes that could be used to foster a transboundary site nomination under criterion (ix). Based on past experience, however, it is important to ensure that any site nominated on this basis is designed with ecologically appropriate boundaries that better support the critical habitats associated to those migratory species. Such a site should be large enough to cover most of the migration routes and encompass the key habitats and areas critical to the maintenance of this migration process over time.

The presence of all of these species, combined with other vertebrates and invertebrates and floral communities that characterise Central Asia ecosystems, may also be considered a strong asset for potential nomination under criterion $(x)$.

22 The database is not up to date and at least three species of large vertebrates are extinct in Central Asia: Caspian tiger (Panthera tigris virgata), Bactrian camel (Camelus bactrianus), and Wild horse (Equuus ferus ferus).

23 CMS website.

24 The species is listed under the CMS Appendix II; a Memorandum of Understanding for Conservation on Restoration and Sustainable Use of the Saiga Antelope was signed in 2006 under the auspices of the CMS and a medium-term International Work Programme has been adopted for the 20152020 period to support the implementation of the MOU (https://www.cms.int/saiga/en/document/ mou-concerning-conservation-restoration-and-sustainable-use-saiga-antelope).

\section{Table 2}

Threatened species in Central Asia (Source: IUCN Red List of threatened species database, 15/04/2018) 


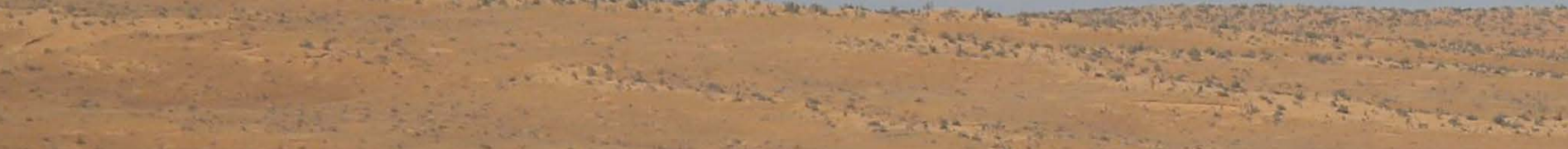

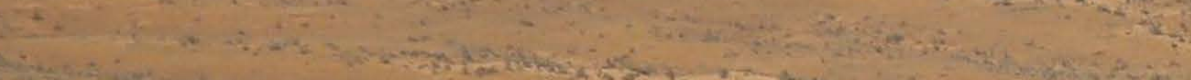

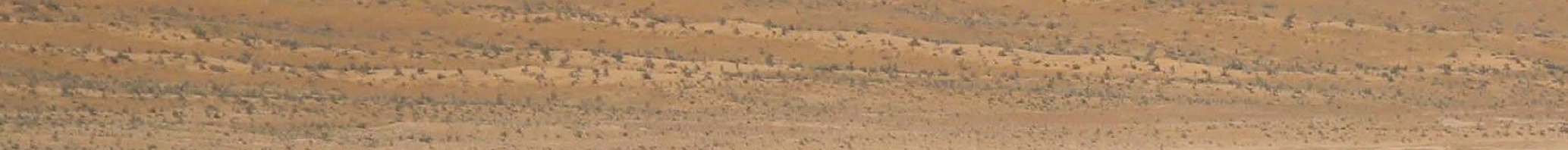

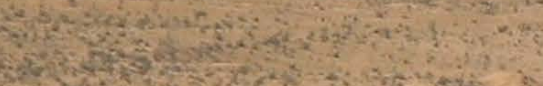

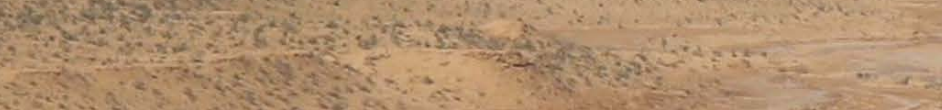

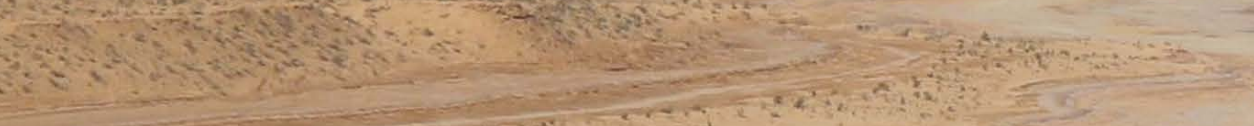

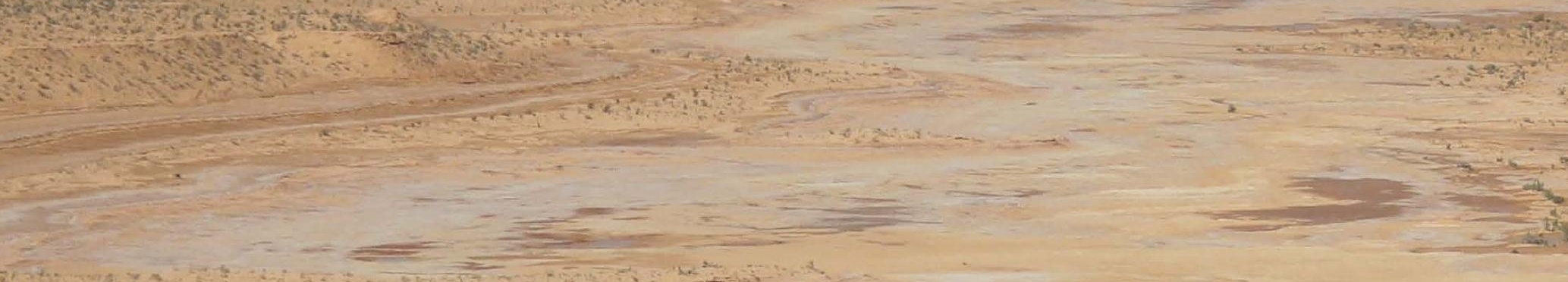

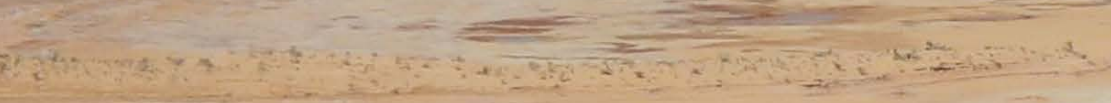

$-\infty+2$

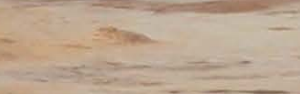
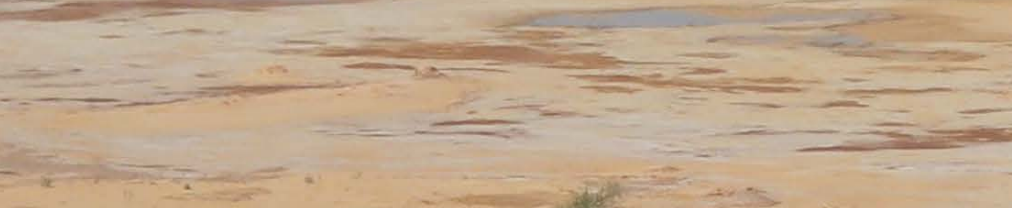

$-1$

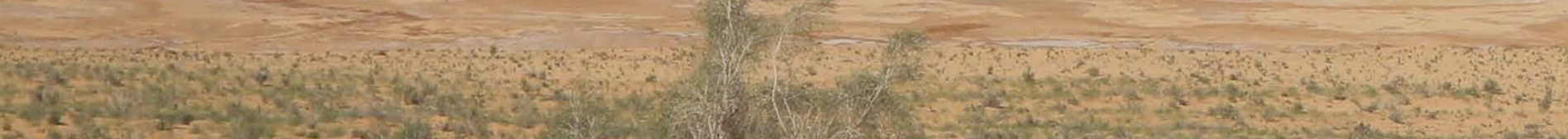

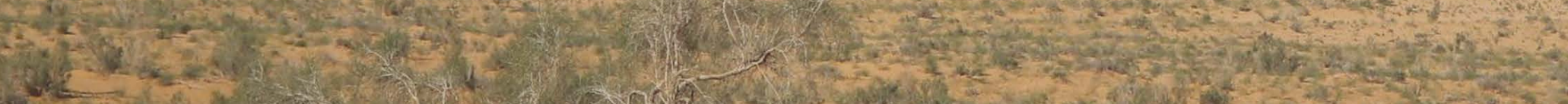
S.

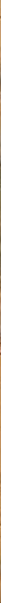




\section{Designated areas in Central Asia}

According to the WH Convention, a nominated site should benefit from an adequate protection regime and be managed properly.

Chapter 2 provides overall information on the current status of PAs in the region, based on the data provided by the State Parties and available on the World Database on Protected Areas (WDPA). ${ }^{25}$ This includes areas recognized internationally for their biodiversity importance, i.e. World Heritage sites, Ramsar sites, and Biosphere Reserves.

\subsection{Protected Areas network}

The following data have been extracted from the WDPA. It should be noted that given the difficulty of obtaining accurate spatial data for protected areas in Central Asia, the data presented herein do not reflect the full reality, as many protected areas in the region are not registered with the WDPA, or existing boundaries may have changed since their original inclusion in the dataset and required updating.

Central Asia currently has at least 290 PAs, covering a total surface over $330,888 \mathrm{~km}^{2}$. Almost half the PAs in the region are in Kazakhstan, accounting for nearly 55\% of the surface area of PAs in Central Asia (Table 3, Map 2).

\begin{tabular}{|l|c|c|c|c|c|c|}
\hline \multirow{2}{*}{ Country } & \multicolumn{4}{|c|}{ Protected areas* } & \multicolumn{3}{c|}{ International designations ** } \\
\cline { 2 - 7 } & Total & $\begin{array}{c}\text { Surface } \\
\left(\mathbf{k m}^{\mathbf{2}}\right)\end{array}$ & $\begin{array}{c}\text { Coverage } \\
\mathbf{( \% )}\end{array}$ & $\begin{array}{c}\text { Natural World } \\
\text { Heritage }\end{array}$ & $\begin{array}{c}\text { Biosphere } \\
\text { Reserve }\end{array}$ & $\begin{array}{c}\text { Ramsar } \\
\text { site }\end{array}$ \\
\hline Kazakhstan & 117 & $243,696.49$ & 8.96 & 2 & 10 & 10 \\
\hline Kyrgyzstan & 85 & $14,632.00$ & 7.37 & 1 & - & 3 \\
\hline Tajikistan & 20 & $31,029.00$ & 21.81 & - & 1 & 1 \\
\hline Turkmenistan & 42 & $20,679.60$ & 4.38 & 1 & 1 & 2 \\
\hline Uzbekistan & 26 & $20,851.76$ & $4.63^{* * *}$ & $\mathbf{8}$ & $\mathbf{1 4}$ & $\mathbf{2 1}$ \\
\hline TOTAL & $\mathbf{2 9 0}$ & $\mathbf{3 3 0 , 8 8 8 . 8 5}$ & $\mathbf{8 . 3 0}$ & $\mathbf{3}$ & & 3 \\
\hline
\end{tabular}

* Modified from CBD, 2019

** International designations may overlap with PAs set up under national designations

*** Includes IUCN categories I-IV and Biosphere Reserves as per the $6^{\text {th }}$ National Report to CBD

Table 3.

Overall, these areas are based on the legal, national status. Whether they meet the Protected Areas network in Central requirements for $\mathrm{WH}$ nomination is a separate question, and case-by-case verification is Asia (various sources). required to determine whether the areas for nomination can also meet the OG's integrity, protection and management requirements. ${ }^{26}$

25 https://www.protectedplanet.net/

26 On this subject: (Sdykova, 2006) for Kazakhstan. 


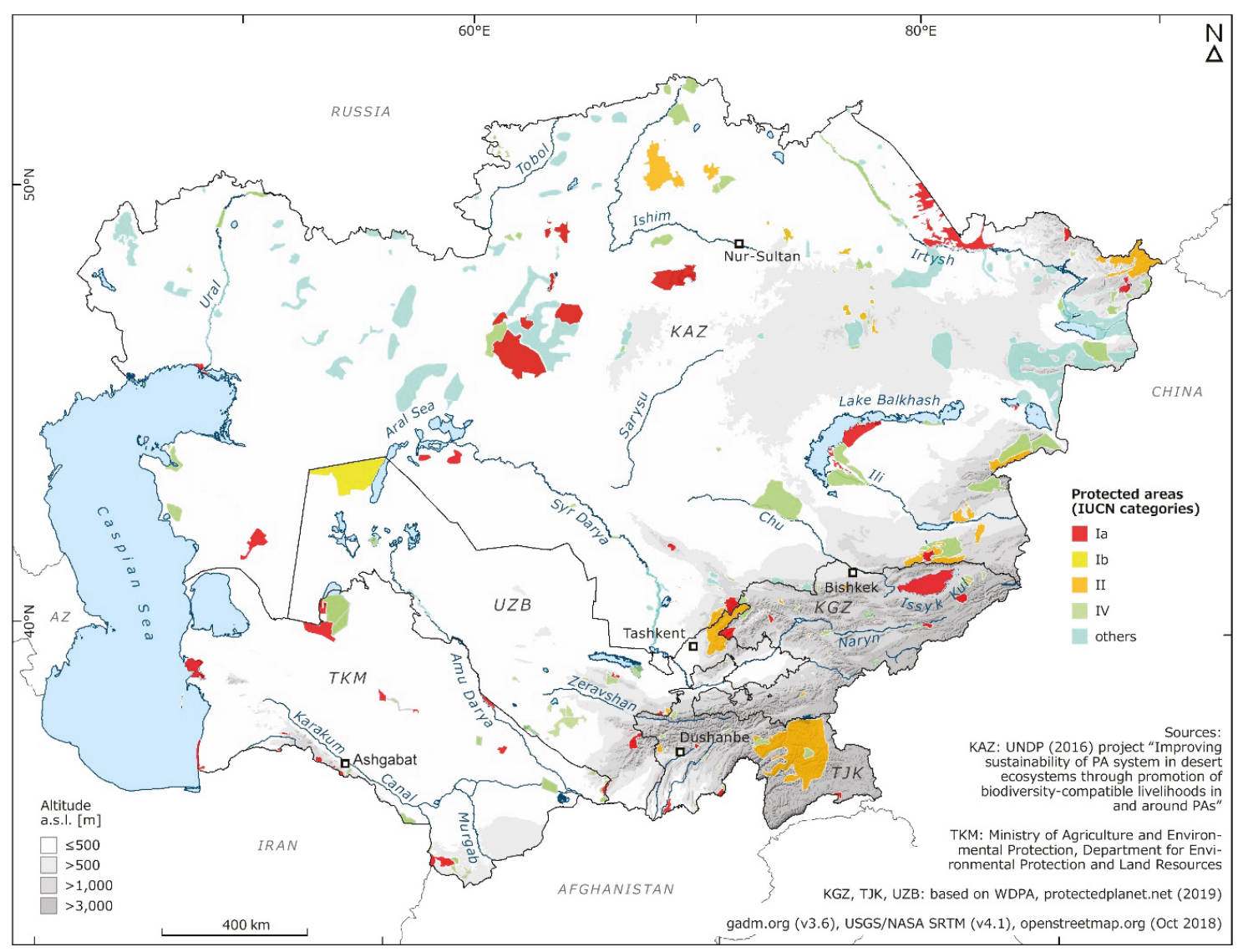

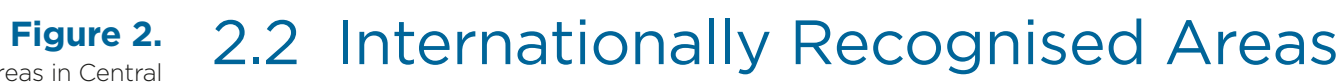

Protected Areas in Central Asia (c) Michael Succow

Foundation.
Areas harbouring particularly high levels of biodiversity, or that are indicative of particularly significant biological processes such that they are significant at an international scale, and areas holding existing designations such as RAMSAR sites, can be good indicators of potentially suitable areas for nomination into the WH List. Existing international designations relevant for criteria (ix) and ( $x$ ) are outlined and discussed in this section in this context.

In total, 30 PAs from the region currently enjoy international recognition. ${ }^{27}$

\subsubsection{UNESCO Biosphere Reserves}

UNESCO Biosphere Reserves (BR) aim to ensure environmental, economic and social sustainability; ${ }^{28}$ each $\mathrm{BR}$ is intended to fulfil three interconnected functions:

- conservation: protecting ecological and cultural diversity, including genetic variation, species, ecosystems, and landscapes, and securing services provided by such diversity;

27 The following figures are slightly different from those published in the 2005 IUCN review; they have been compiled from UNEP-WCMC's online WDPA on 3 April 2018 (https://www.protectedplanet.net/.

28 Through: (1) the development and coordination of demonstration areas and learning sites with the aim of maintaining and developing ecological and cultural diversity and securing ecosystem services for human well-being; (2) the development and integration of knowledge, including science, to advance understanding of interactions between people and the rest of nature; (3) building global capacity for the management of complex socio-ecological systems, particularly through encouraging greater dialogue at the science-policy interface; environmental education; and multi-media outreach to the wider community (http://www.unesco. org/new/en/natural-sciences/environment/ecological-sciences/biosphere-reserves/main-characteristics/ functions/). 
- development: fostering economic and human development that is environmentally and socially sustainable, and culturally appropriate;

- logistic support: facilitating demonstration projects, environmental education, and sustainable development education and training, research, and monitoring. While education, research, monitoring and capacity enhancement are seen as components of the logistic or knowledge-generation function of BR, they are also integral to the conservation and development functions.

\begin{tabular}{|l|l|l|}
\hline Countries & Biosphere Reserve & Year of designation \\
\hline Kazakhstan (10) & Korgalzhyn & 2012 \\
& Alakol & 2013 \\
& Ak-Zhayik & 2014 \\
& Aksu-Zhabagly & 2015 \\
& Barsakelmes & 2016 (former Katon-Karagay 2014) \\
& Great Altai & 2017 \\
& Altyn Emel & 2017 \\
& Karatau & 2017 \\
& Charyn & 2018 \\
\hline Kyrgyzstan (2) & Zhongar & 2018 \\
\hline Tajikistan (0) & Sary-Chelek & 1978 (reviewed in 2013) \\
\hline Turkmenistan (1) & Issyk Kul & 2001 (reviewed in 2013) \\
\hline Uzbekistan (1) & Repetek & - \\
\hline
\end{tabular}

There are currently 14 UNESCO BRs in Central Asia located in four countries (Table 4, Figure 3). Only Tajkistan does not currently have any UNESCO BRs, while UNESCO BR is a transboundary site between Kazakhstan and the Russian Federation (Great Altai).

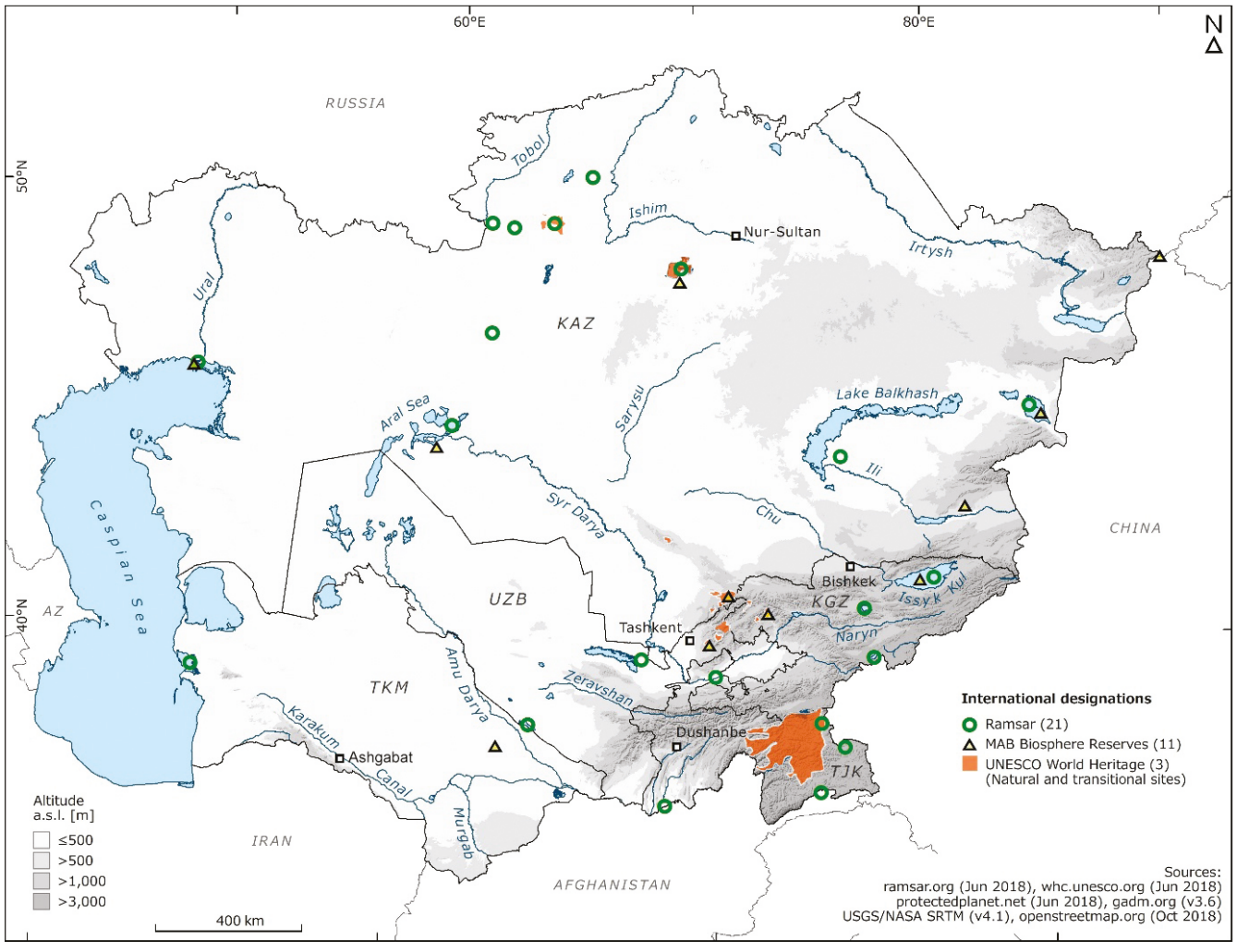

Table 4.

UNESCO BR network in Central Asia (Source: UNESCO/MAB website, 02/04/2019)

\section{Figure 3.}

International designations of areas in Central Asia (c) Michael Succow Foundation. 


\subsubsection{Ramsar Sites}

Based on the nine criteria for identifying Wetlands of International Importance (Box 1), to date 21 Ramsar Sites have been designated in the region and cover $47,880 \mathrm{~km}^{2}$ (Table 5 and Map 8).

\begin{tabular}{|c|c|c|c|c|}
\hline Country & Site name & $\begin{array}{l}\text { Year of } \\
\text { designation }\end{array}$ & $\begin{array}{l}\text { Area } \\
\left(\mathrm{km}^{2}\right)\end{array}$ & $\begin{array}{l}\text { Management } \\
\text { plan } \\
\text { implemented }\end{array}$ \\
\hline \multirow[t]{10}{*}{ Kazakhstan (10) } & Kourgaldzhin and Tengiz Lakes & \multirow[t]{2}{*}{1976} & 2605 & No \\
\hline & Lakes of the lower Turgay and Irgiz & & 3480 & No \\
\hline & Koibagar-Tyuntyugur Lake System & \multirow[t]{6}{*}{2009} & 580 & No \\
\hline & $\begin{array}{l}\text { Ural River Delta and adjacent Caspian } \\
\text { Sea coast }\end{array}$ & & 1115 & No \\
\hline & Alakol-Sasykkol Lakes System & & 9147 & No \\
\hline & Naurzum Lake System & & 1397 & Yes \\
\hline & Zharsor-Urkash Lake System & & 412 & No \\
\hline & Kulykol-Taldykol Lake System & & 83 & No \\
\hline & $\begin{array}{l}\text { Lesser Aral Sea and Delta of the } \\
\text { Syrdarya River }\end{array}$ & \multirow[t]{2}{*}{2012} & 3300 & Yes \\
\hline & Ili River Delta and South Lake Balkhash & & 9766 & Yes \\
\hline \multirow[t]{3}{*}{ Kyrgyzstan (3) } & $\begin{array}{l}\text { Issyk-kul State Nature Reserve with } \\
\text { Issyk-kul Lake }\end{array}$ & 2002 & 6264 & No \\
\hline & Chatyr Kul & 2005 & 161 & $\begin{array}{l}\text { Partially } \\
\text { covered by } \\
\text { the Karatal } \\
\text { Japalyk } \\
\text { Management } \\
\text { Plan }\end{array}$ \\
\hline & Son-Kol Lake & 2011 & 368 & Idem supra \\
\hline \multirow[t]{5}{*}{ Tajikistan (5) } & Karakul Lake & \multirow[t]{5}{*}{2001} & 364 & No \\
\hline & Shorkul and Rangkul Lakes & & 24 & No \\
\hline & Zorkul Lake & & 38 & No \\
\hline & Kayrakum Reservoir & & 520 & No \\
\hline & Lower part of Pyandj River & & - & No \\
\hline Turkmenistan (1) & Turkmenbashy Bay & 2008 & 2671 & No \\
\hline \multirow[t]{2}{*}{ Uzbekistan (2) } & Aydar-Arnasay Lakes system & 2008 & 5271 & No \\
\hline & Lake Dengizkul & 2001 & 313 & No \\
\hline
\end{tabular}

Table 5.

Ramsar Sites in Central Asia (Source: Ramsar website, 13/02/2019) 


\section{THE RAMSAR SITES CRITERIA \\ The nine criteria for identifying Wetlands of International Importance}

\section{GROUP A - SITES CONTAINING REPRESENTATIVE, RARE OR UNIQUE WETLAND TYPES}

Criterion 1: a wetland should be considered internationally important if it contains a representative, rare, or unique example of a natural or near-natural wetland type found within the appropriate biogeographic region.

\section{GROUP B - SITES OF INTERNATIONAL IMPORTANCE FOR CONSERVING BIOLOGICAL DIVERSITY CRITERIA BASED ON SPECIES AND ECOLOGICAL COMMUNITIES}

Criterion 2: a wetland should be considered internationally important if it supports vulnerable, endangered, or critically endangered species or threatened ecological communities.

Criterion 3: a wetland should be considered internationally important if it supports populations of plant and/or animal species important for maintaining the biological diversity of a particular biogeographic region.

Criterion 4: a wetland should be considered.internationally important if it supports plant and/or animal species at a critical stage in their life cycles or provides refuge during adverse conditions.

\section{Specific criteria based on water birds}

Criterion 5: a wetland should be considered internationally important if it regularly supports 20,000 or more water birds.

Criterion 6: a wetland should be considered internationally important if it regularly supports $1 \%$ of the individuals in a population of one species or subspecies of water birds.

\section{Specific criteria based on fish}

Criterion 7: a wetland should be considered internationally important if it supports a significant proportion of indigenous fish subspecies, species or families, life-history stages, species interactions and/or populations that are representative of wetland benefits and/or values and thereby contributes to global biological diversity.

Criterion 8: a wetland should be considered internationally important if it is an important source of food for fishes, spawning ground, nursery and/or migration path on which fish stocks, either within the wetland or elsewhere, depend.

\section{Specific criteria based on other taxa}

Criterion 9: a wetland should be considered internationally important if it regularly supports $1 \%$ of the individuals in a population of one species or subspecies of wetland-dependent non-avian animal species.

The international protected area designations discussed within this section should not be seen as implying a specific legal status of protection for any given area, or fulfilment of the conservation and management requirements of the WH Convention. However, in some cases, they may facilitate the identification and prioritisation of areas having high

\section{Box 1.}

The Ramsar Sites criteria. (Source: Ramsar website).

biodiversity value to increase their chances of nomination. 


\section{Natural World Heritage sites in Central Asia}

Chapter 3 provides an overview of the current situation of the WH sites in the region. A preliminary review is presented of the potential of sites included in the TLs for nomination under natural criteria, as appraised by the experts and specialists consulted during the study.

\subsection{The World Heritage List}

Three natural sites are currently inscribed on the WH List (Saryarka - Steppe and Lakes of Northern Kazakhstan, Western Tien-Shan and Tajik National Park (Mountains of the Pamirs). Of these sites, one (Western Tien Shan) is a serial transnational site, occurring within three of the five countries (Table 6). ${ }^{29}$

Another site, Mountain Ecosystems of Koyentag, was nominated by Turkmenistan in 2015 under criteria ( $\mathrm{vii}$ ), (ix) and ( $\mathrm{x}$ ). The WHC deferred the examination of this nomination to allow the State Party to prepare a revised nomination, as follows (Decision WHC 40 COM 8B.10): ${ }^{30}$

- the State Party was recommended: (1) to monitor grazing pressures in the designated wildlife sanctuaries to regulate stock numbers and reduce pressure on native vegetation and natural systems; (2) to more effectively plan for increasing tourism demand, including the development of appropriately scaled and low impact tourismrelated infrastructure; (3) to ensure that proposals to establish cable car access are subject to careful consideration and rigorous environmental impact assessment and to ensure that no mining prospecting licenses and/or operations will be permitted within protected areas comprising the Mountain Ecosystems of Koyendag and its BZ, and (4) that any mining activity that might impact this site is subject to rigorous environmental and social impact assessment;

- the States Parties of Turkmenistan and Uzbekistan were also encouraged to enhance collaboration to improve coordination between Koytendag State Nature Reserve (Turkmenistan) and the adjoining Surkhan Strict Nature Reserve (SNR) (Uzbekistan), to support improved transboundary management of wildlife populations.

Furthermore, Tajik National Park (Mountains of the Pamirs) was inscribed on the WH list in 2013 under criteria (vii) and (viii). The WHC took this opportunity to encourage the State Party to assess the possibility of developing opportunities for future transboundary and potentially serial nominations with neighbour countries in the inner Asian high mountains and deserts (Decision WHC 37 COM 8B.14). ${ }^{31}$

29 A serial site includes several components that may occur on the territory of a single State Party (serial national property) or within the territory of different States Parties, which need not be contiguous (serial transboundary property).

30 http://whc.unesco.org/en/decisions/?id decision=6789\&.

31 http://whc.unesco.org/en/decisions/?id decision=5130\& 
In summary, a transboundary or transnational nomination encompassing several areas could thus be considered as a possible line of approach for new nominations in the future (see Chapter 5).

\begin{tabular}{|c|c|c|c|c|c|c|}
\hline \multirow[t]{2}{*}{ Country } & \multirow[t]{2}{*}{ Name } & \multirow[t]{2}{*}{ Category } & \multirow{2}{*}{$\begin{array}{c}\text { Year of } \\
\text { inscription }\end{array}$} & \multicolumn{2}{|c|}{ Criteria } & \multirow[t]{2}{*}{ Additional information } \\
\hline & & & & $\mathbf{I X}$ & $x$ & \\
\hline \multirow[t]{2}{*}{ Kazakhstan } & $\begin{array}{l}\text { Saryarka - } \\
\text { Steppe and } \\
\text { Lakes of } \\
\text { Northern } \\
\text { Kazakhstan }\end{array}$ & Natural & 2008 & $\checkmark$ & & $\begin{array}{l}1 \text { Biosphere Reserve } \\
\text { (Korgalzhyn) } \\
2 \text { Ramsar Sites (Naurzum Lake } \\
\text { System and Tengiz-Korgalzhyn } \\
\text { Lake System) }\end{array}$ \\
\hline & $\begin{array}{l}\text { Western Tien- } \\
\text { Shan }\end{array}$ & Natural & 2016 & & $\checkmark$ & Serial Transnational Site \\
\hline Kyrgyzstan & $\begin{array}{l}\text { Western Tien- } \\
\text { Shan }\end{array}$ & Natural & 2016 & & & Serial Transnational Site \\
\hline Tajikistan & Tajik NP & Natural & 2013 & & & Criteria (vii) and (viii) \\
\hline Uzbekistan & $\begin{array}{l}\text { Western Tien- } \\
\text { Shan }\end{array}$ & Natural & 2016 & & $\checkmark$ & Serial Transnational Site \\
\hline
\end{tabular}

\section{Table 6. 3.2 Tentative Lists} the World Heritage

List (Source: UNESCO WH web site, 13/02/2019)

A Tentative List (TL) is an inventory of those properties which each State Party intends to consider for nomination. The first step a country should take is to conduct an inventory listing of natural or mixed heritage of potential OUVs suitable for inscription on the WH List (IUCN, 2011). ${ }^{32}$

TLs are mandatory for State Parties towards the nomination of new WH sites, ${ }^{33}$ and they should include the names of properties that State Parties intend to nominate in coming years.

Currently, 17 natural and six mixed sites are included on the TLs of four of the five countries (Table 7); Kyrgyzstan has no natural or mixed site on its TL. ${ }^{34}$

All current TLs have been in place for a long time and have remained more or less unchanged over the years, with no updates in the past decade. As such, it would be worth reviewing the TLs to better understand the site OUV and their potential for meeting $\mathrm{WH}$ Convention requirements as the basis for future nominations.

Based on analysis of the literature and numerous exchanges with national stakeholders during and between the workshops, this lack of recent updates to the TLs may, among other reasons, be attributed to:

- difficult access to available data on biodiversity in the region, which is often only available in Russian and in no other working languages;

- poor international recognition on the importance of the region for biodiversity, even though this region is one of the least represented on the current $\mathrm{WH}$ list;

\footnotetext{
32 Chapter II.C.

33 OG, Section 62-76.

34 On that subject see: UNESCO, 2002/2004
} 
- weak analysis of the potential OUV of sites on current TLs due to insufficient knowledge of the criteria, conservation and management, $\mathrm{WH}$ requirements and lack of regional/local expertise on $\mathrm{WH}$;

- $\quad$ absence of a comparative analysis showing how sites included in the TLs compare to other sites globally;

- $\quad$ presence of natural and/or mixed sites in TLs that may not be the most appropriate for nomination under criteria (ix) and ( $x$ );

- insufficient consideration of sites at the ecosystem level, such as mountain ranges or deserts, with outstanding ecological functionalities and representing processes in the evolution and development of ecosystems and communities, in line with criterion (ix):

- insufficient skills and institutional capacities dedicated to the WH in the countries.

New PAs have been set up since the inscription of the sites on the TLs. Moreover, land use under evolving socio-economic development contexts in the region, together with other drivers of change across multiple scales may have altered the values under which the sites were originally included within the TLs.

Each site inscribed on the TLs, and each new site considered to have potential for nomination, should be properly assessed to summarise the current status of the site's values, pressure and potential threats to those values, and the protection and management contexts of the site (Annexes 7 and 8). This cannot be based on a simple desk review and requires further in-depth field study.

Table 7.

Sites included on the Central Asian countries' TLS (Source: UNESCO WH web site. 13/02/2019).

\begin{tabular}{|c|c|c|c|c|c|c|c|c|}
\hline \multirow[t]{2}{*}{ Country } & \multirow[t]{2}{*}{ Name } & \multirow[t]{2}{*}{ Category } & \multirow{2}{*}{$\begin{array}{c}\text { Date of } \\
\text { submission }\end{array}$} & \multicolumn{4}{|c|}{ Biodiversity criteria } & \multirow{2}{*}{$\begin{array}{l}\text { Other } \\
\text { criteria }\end{array}$} \\
\hline & & & & IX & $\mathbf{X}$ & VII & VIII & \\
\hline \multirow[t]{8}{*}{ Kazakhstan } & $\begin{array}{l}\text { Aksu-Zhabagly State } \\
\text { Natural Reserve }\end{array}$ & \multirow[t]{3}{*}{ natural } & \multirow[t]{3}{*}{$06 / 02 / 2002$} & $V$ & $\checkmark$ & & & \\
\hline & $\begin{array}{l}\text { Northern Tyan-Shan } \\
\text { (Ile-Alatau State } \\
\text { National Nature Park) }\end{array}$ & & & & & & & \\
\hline & $\begin{array}{l}\text { Altyn-Emel State } \\
\text { National Nature Park }\end{array}$ & & & & $V$ & & $\checkmark$ & \\
\hline & $\begin{array}{l}\text { Petroglyphs of } \\
\text { Eshkiolmes }\end{array}$ & \multirow[t]{5}{*}{ mixed } & \multirow[t]{5}{*}{ 24/09/1998 } & \multirow{2}{*}{\multicolumn{2}{|c|}{$\begin{array}{l}\text { Not yet } \\
\text { determined }\end{array}$}} & & & \\
\hline & $\begin{array}{l}\text { Turkic sanctuary of } \\
\text { Merke }\end{array}$ & & & & & & & \\
\hline & $\begin{array}{l}\text { Barrows with stone } \\
\text { ranges of the Tasmola } \\
\text { culture }\end{array}$ & & & \multicolumn{2}{|c|}{$\begin{array}{l}\text { Not yet } \\
\text { determined }\end{array}$} & & & \\
\hline & $\begin{array}{l}\text { Palaeolithic sites and } \\
\text { geomorphology of } \\
\text { Karatau Mountain } \\
\text { range }\end{array}$ & & & \multicolumn{2}{|c|}{$\begin{array}{l}\text { Not yet } \\
\text { determined }\end{array}$} & & & \\
\hline & $\begin{array}{l}\text { Cultural landscape of } \\
\text { Ulytau }\end{array}$ & & & \multicolumn{2}{|c|}{$\begin{array}{l}\text { Not yet } \\
\text { determined }\end{array}$} & & & \\
\hline
\end{tabular}




\begin{tabular}{|c|c|c|c|c|c|c|c|}
\hline Kyrgyzstan & No natural sites on the & tative List & & & & & \\
\hline \multirow[t]{5}{*}{ Tajikistan } & Fann Mountains & \multirow[t]{5}{*}{ natural } & \multirow[t]{5}{*}{ 04/04/2006 } & & $\checkmark$ & $\checkmark$ & \\
\hline & Tigrovaya Balka & & & $\checkmark$ & & & \\
\hline & Zakaznik Kusavlisay & & & & & & \\
\hline & $\begin{array}{l}\text { Dashti Djum State } \\
\text { Reserve }\end{array}$ & & & & & & \\
\hline & Zorkul State Reserve & & & & $\checkmark$ & $V$ & \\
\hline \multirow[t]{6}{*}{ Turkmenistan } & $\begin{array}{l}\text { Badhyz State Nature } \\
\text { Reserve }\end{array}$ & & \multirow[t]{6}{*}{$16 / 03 / 2009$} & & & & \\
\hline & $\begin{array}{l}\text { Syunt Hasardag State } \\
\text { Nature Reserve }\end{array}$ & & & & & & \\
\hline & $\begin{array}{l}\text { Dinosaurs and Caves } \\
\text { of Koytendag }\end{array}$ & & & & & & \\
\hline & $\begin{array}{l}\text { Repetek State } \\
\text { Biosphere Reserve }\end{array}$ & & & & & & \\
\hline & $\begin{array}{l}\text { Amudarya State } \\
\text { Nature Reserve }\end{array}$ & & & & & & \\
\hline & $\begin{array}{l}\text { Hazar State Nature } \\
\text { Reserve }\end{array}$ & & & & & & \\
\hline \multirow[t]{5}{*}{ Uzbekistan } & Zaamin Mountains & \multirow[t]{3}{*}{ natural } & \multirow[t]{5}{*}{ 18/01/2008 } & $V$ & $V$ & & \\
\hline & Shokhimardon & & & & & & \\
\hline & Gissar Mountains & & & & $\checkmark$ & & \\
\hline & Boysun & \multirow[t]{2}{*}{ mixed } & & & & & $\begin{array}{l}\text { IV and } \\
\vee\end{array}$ \\
\hline & Sarmishsay & & & $\checkmark$ & & & VI \\
\hline
\end{tabular}

The Aksu-Zhabagly State Natural Reserve was inscribed on the WH List in 2016, as a component of the Western Tien-Shan serial transnational property, and accordingly, should be removed from the TL of Kazakhstan.

A brief review of the sites currently listed on the TLs was performed by the workshop participants during the project. Accordingly, the following sites are among those included on TLs that may still have potential for nomination under at least one natural criterion (Table 8): ${ }^{35}$

- Northern Tien-Shan;

- Altyn Emel;

- Palaeolithic sites of Kazakhstan;

- High mountain deserts of Central Tien-Shan;

- Tigrovaya Balka;

- Fann Mountains;

- Zorkul Zapovednik;

- Shokhimardon (Shakhimardan);

- Zaamin Mountains and Gissar Mountains.

35 This analysis should however be confirmed and checked further in the field before one site is nominated. 


\begin{tabular}{|c|c|c|}
\hline & \multirow{4}{*}{$\begin{array}{l}\text { Table } \mathbf{8 .} \\
\text { Preliminary } \\
\text { review of the } \\
\text { sites included in }\end{array}$} \\
\hline Kazakhstan & & \\
\hline \multicolumn{2}{|c|}{ Petroglyphs of Eshkiolmes, Merke, Tasmola } & \\
\hline Relevance & no information & \\
\hline Criteria & no information & \\
\hline Values & to be specified under biodiversity criteria & \\
\hline Threats & no information & \\
\hline Protection & no protection & \\
\hline Management & no information & \\
\hline \multicolumn{2}{|c|}{ Northern Tien-Shan (Ile-Alatau) } & \\
\hline Relevance & good integrity & \\
\hline Criteria & ix and $\times(+v i i)$ & \\
\hline Values & good & \\
\hline Threats & medium (tourism; proximity to Almaty) & \\
\hline Protection & seems to meet $\bigcirc G$ requirements & \\
\hline Management & seems to meet $\bigcirc G$ requirements & \\
\hline \multicolumn{2}{|l|}{ Altyn-Emel } & \\
\hline Relevance & good & \\
\hline Criteria & ix and $\times(+$ vii and viii) & \\
\hline Values & Good $(1 \text { IBA })^{35}$ & \\
\hline Threats & medium (pasture and tourism) & \\
\hline Protection & seems to meet $O G$ requirements and is enforced properly & \\
\hline Management & seems to meet $O G$ requirements and is implemented properly & \\
\hline \multicolumn{2}{|c|}{ Palaeolithic sites of Kazakhstan } & \\
\hline Relevance & $\begin{array}{l}\text { not relevant (further studies); could be potentially added to } \\
\text { Western Tien-Shan. Included within the Karatau Reserve. }\end{array}$ & \\
\hline Criteria & $\times(+$ vii and viii) & \\
\hline Values & good & \\
\hline Threats & low & \\
\hline Protection & seems to meet $O G$ requirements and is enforced properly & \\
\hline Management & some concern in case of enlarged Western Tien-Shan & \\
\hline \multicolumn{2}{|c|}{ High mountain deserts of Central Tien-Shan ${ }^{36}$} & \\
\hline Relevance & $\begin{array}{l}\text { glaciers; zone of flow formation of Syrdarya basin rivers; } \\
\text { endangered and endemic species (requires additional detail). }\end{array}$ & \\
\hline Criteria & $x(+$ viii $)$ & \\
\hline Values & good & \\
\hline Threats & medium (degradation of grazing areas; mining; climate change) & \\
\hline Protection & seems to meet OG requirements (state nature reserve) & \\
\hline Management & seems to meet $\bigcirc G$ requirements & \\
\hline \multicolumn{2}{|l|}{ Kyrgyzstan } & \\
\hline \multicolumn{2}{|c|}{ Issyk-Kul - natural and cultural landscape (Southern shore) ${ }^{37}$} & \\
\hline Relevance & $\begin{array}{l}\text { spruce forests, riparian forests, endemic and endangered plant } \\
\text { and animal species }\end{array}$ & \\
\hline
\end{tabular}

$36 \mathrm{KZ} 101$ (http://datazone.birdlife.org/site/factsheet/altyn-emel-national-park-iba-kazakhstan).

37 Listed as part of the "Silk road sites" in Kazakhstan, and only under cultural criteria.

38 Listed as part of the "Silk road sites" in Kyrgyzstan, and only under cultural criteria. 


\begin{tabular}{|c|c|}
\hline Criteria & ix and $x(+$ iii, vi and vii) \\
\hline Values & $2 \mathrm{IBAs}^{39}$ \\
\hline Threats & $\begin{array}{l}\text { high (fragmentation of ecosystems; degradation of grazing areas; } \\
\text { mining; poorly planned tourism infrastructure; unsustainable use) }\end{array}$ \\
\hline Protection & $\begin{array}{l}\text { seems to meet } O G \text { requirements (state nature reserve }+5 \text { wildlife } \\
\text { reserves and Karakol Nature Park) }\end{array}$ \\
\hline Management & no information \\
\hline \multicolumn{2}{|l|}{ Tajikistan } \\
\hline \multicolumn{2}{|l|}{ Kusavlisay } \\
\hline Relevance & only 1 criterion, low integrity \\
\hline Criteria & vii \\
\hline Values & declining populations \\
\hline Threats & low \\
\hline Protection & low level (Zakaznik) \\
\hline Management & no management system, ecotourism \\
\hline \multicolumn{2}{|c|}{ Tigrovaya Balka } \\
\hline Relevance & high integrity \\
\hline Criteria & ix \\
\hline Values & Ecosystems $(+1 \text { IBA })^{40}$ \\
\hline Threats & medium (artificial regulation of the flow of the Vakhsh River) \\
\hline Protection & seems to meeting $O G$ requirements (state nature reserve + BZ) \\
\hline Management & $\begin{array}{l}\text { seems to meet } O G \text { requirements and is properly implemented; } \\
\text { ecotourism }\end{array}$ \\
\hline \multicolumn{2}{|c|}{ Fann Mountains } \\
\hline Relevance & $\begin{array}{l}\text { important biodiversity (mountain wetlands and other types of } \\
\text { ecosystems) }\end{array}$ \\
\hline Criteria & $x(+v i i)$ \\
\hline Values & ecosystems; intact habitats \\
\hline Threats & very low \\
\hline Protection & no information (very remote part of the country) \\
\hline Management & no BZ yet \\
\hline \multicolumn{2}{|l|}{ Zorkul } \\
\hline Relevance & important landscapes and biodiversity \\
\hline Criteria & $x$ \\
\hline Values & ecosystems \\
\hline Threats & widespread livestock grazing (Karimov et al., 2018) \\
\hline Protection & $\begin{array}{l}\text { seems to meet OG requirements (state nature reserve) but there } \\
\text { is a lack of enforcement; } \mathrm{BZ}(+1 \text { IBA) }\end{array}$ \\
\hline Management & promotion of ecotourism \\
\hline \multicolumn{2}{|l|}{ Dashti Djum } \\
\hline Relevance & low integrity \\
\hline Criteria & vii \\
\hline Values & no information \\
\hline
\end{tabular}

39 http://datazone.birdlife.org/site/

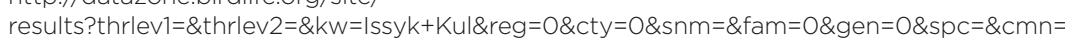

40 TJ 009 (http://datazone.birdlife.org/site/factsheet/tigrovaya-balka-nature-reserve-iba-tajikistan). 


\begin{tabular}{|c|c|}
\hline Threats & widespread livestock grazing and very significant poaching \\
\hline Protection & $\begin{array}{l}\text { seems to meet } O G \text { requirements (state nature reserve) but there } \\
\text { is a lack of enforcement; no BZ }\end{array}$ \\
\hline Management & promotion of ecotourism \\
\hline \multicolumn{2}{|l|}{ Turkmenistan } \\
\hline \multicolumn{2}{|l|}{ Amudarya } \\
\hline Relevance & $\begin{array}{l}\text { important landscapes (tugaï forest + desert ecosystems) but low } \\
\text { integrity }\end{array}$ \\
\hline Criteria & $x$ \\
\hline Values & ecosystems (tugaï forests + desert ecosystems) $\left(+1\right.$ IBA) ${ }^{41}$ \\
\hline Threats & high (poaching, low integrity) \\
\hline Protection & $\begin{array}{l}\text { seems to meet } O G \text { requirements but there is a lack of } \\
\text { enforcement; no BZ }\end{array}$ \\
\hline Management & no information \\
\hline \multicolumn{2}{|l|}{ Badhyz } \\
\hline Relevance & critical corridor \\
\hline Criteria & ix and $\times(+$ vii $)$ \\
\hline Values & no information (1 IBA $)^{42}$ \\
\hline Threats & medium (livestock and settlements) \\
\hline Protection & $\begin{array}{l}\text { seems to meet } O G \text { requirements (state nature reserve) but there } \\
\text { is a lack of enforcement }\end{array}$ \\
\hline Management & weak \\
\hline \multicolumn{2}{|c|}{ Dinosaurs and caves of Koytendag } \\
\hline Relevance & nomination deferred \\
\hline Criteria & x (+ viii) \\
\hline Values & $\begin{array}{l}\left(1 \text { IBA) }{ }^{43} \text { but does not meet criterion (x) (Decision WHC 4OCOM }\right. \\
8 \text { B.10); } 44 \text { low integrity }\end{array}$ \\
\hline Threats & grazing, mining, tourism \\
\hline Protection & seems to meet $O G$ requirements (state nature reserve) \\
\hline Management & weak \\
\hline \multicolumn{2}{|c|}{ Syunt Hasardag } \\
\hline Relevance & important biodiversity (mixed arid and subtropical climate) \\
\hline Criteria & $x$ \\
\hline Values & $\begin{array}{l}\text { similar areas to other mountainous reserves in Central Asia, such } \\
\text { as Chatkal in Uzbekistan, Aksu-Dzhabagly in Kazakhstan and } \\
\text { Sary-Chelek in Kyrgyzstan, but located much further west and } \\
\text { marked by Caucasian influences }\end{array}$ \\
\hline Threats & farming and grazing \\
\hline Protection & seems to meet $\bigcirc G$ requirements (state nature reserve) \\
\hline Management & no information \\
\hline \multicolumn{2}{|l|}{ Hazar } \\
\hline Relevance & $\begin{array}{l}\text { important wetland area (partly designated as Ramsar site/ } \\
\text { Turkmenbashi Bay) }\end{array}$ \\
\hline
\end{tabular}

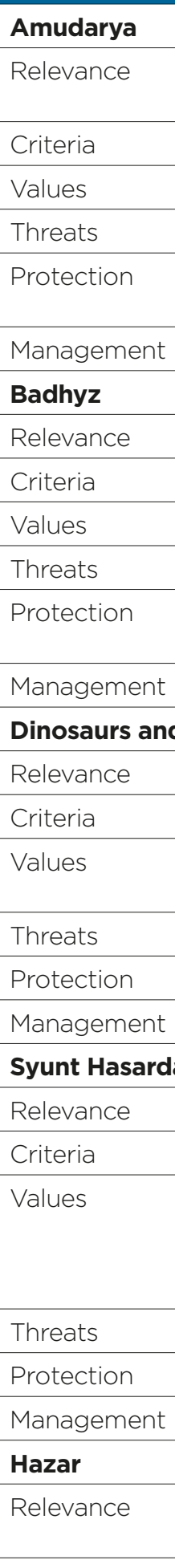

UZ 047 (http://datazone.birdlife.org/site/factsheet/amudarya-floodlands-near-termez-iba-uzbekistan).

TM 038 (http://datazone.birdlife.org/site/factsheet/badhyz-iba-turkmenistan).

TM 050 (http://datazone.birdlife.org/site/factsheet/koytendag-iba-turkmenistan).

http://whc.unesco.org/en/decisions/?id decision=6789\&. 


\begin{tabular}{|c|c|}
\hline Criteria & $x$ \\
\hline Values & $\begin{array}{l}\text { important site for migratory and wintering birds, qualified as } \\
\text { an IBA; contains several endemic and rare species of marine } \\
\text { mammals (Caspian seal Pusa caspica (EN)) and serves as } \\
\text { feeding ground for fish during their migration, fattening and } \\
\text { spawning periods (Caspian lamprey Caspiomyzon wagneri } \\
\text { (NT), Fringebarbel sturgeon Acipenser nudiventris (EN), Stellate } \\
\text { sturgeon Acipenser stellatus (EN), Russian sturgeon Acipenser } \\
\text { gueldenstaedtii (EN), and European sturgeon Huso huso (EN). } \\
\text { Beloribitsa Stenodus leucichthys (EX in the wild) (+ } 1 \text { IBA) }\end{array}$ \\
\hline Threats & $\begin{array}{l}\text { high (oil pollution, habitat disturbance, and illegal hunting of } \\
\text { migratory waterbirds }{ }^{46} \text { ) }\end{array}$ \\
\hline Protection & seems to meet $O G$ requirements (state nature reserve + BZ) \\
\hline Management & no information \\
\hline \multicolumn{2}{|c|}{ Repetek State Biosphere Reserve } \\
\hline Relevance & important biodiversity \\
\hline Criteria & $x$ \\
\hline Values & key plant species and important for migratory birds (nesting) \\
\hline Threats & low, remote area (few settlements and potential overgrazing) \\
\hline Protection & $\begin{array}{l}\text { seems to meet } O G \text { requirements (state nature reserve + } \\
\text { biosphere reserve) }\left(+1 \mathrm{IBA} A^{47}\right)\end{array}$ \\
\hline Management & seems to meet $O G$ requirements \\
\hline \multicolumn{2}{|l|}{ Uzbekistan } \\
\hline \multicolumn{2}{|c|}{ Shokhimardon (Shakhimardan) } \\
\hline Relevance & large glaciers, mountain rivers, alpine lakes, relict Juglans forests \\
\hline Criteria & ix and $x$ \\
\hline Values & good state; enclave on the territory of Kyrgyzstan \\
\hline Threats & Low \\
\hline Protection & low level of concern \\
\hline Management & low level of concern \\
\hline \multicolumn{2}{|c|}{ Zaamin Mountains } \\
\hline Relevance & juniper forests (3 species) \\
\hline Criteria & ix and $\times(+$ vii $)$ \\
\hline Values & good state \\
\hline Threats & low \\
\hline Protection & seems to meet $\bigcirc G$ requirements \\
\hline Management & seems to meet $\bigcirc G$ requirements \\
\hline \multicolumn{2}{|c|}{ Gissar Mountains } \\
\hline Relevance & $\begin{array}{l}\text { important biodiversity and threatened species (+ geological } \\
\text { values) }\end{array}$ \\
\hline Criteria & x (+ vii and viii) \\
\hline Values & excellent $\left(+1 \mathrm{IBA}^{48}\right)$ \\
\hline Threats & very low (good integrity) \\
\hline
\end{tabular}

45 TM 006 (http://datazone.birdlife.org/site/factsheet/turkmenbashy-bay-iba-turkmenistan).

46 https://rsis.ramsar.org/ris/1855.

47 TM 045 (http://datazone.birdlife.org/site/factsheet/repetek-iba-turkmenistan).

48 UZ 042 (http://datazone.birdlife.org/site/factsheet/gissar-state-nature-reserve-iba-uzbekistan) 


\begin{tabular}{|l|l|}
\hline Protection & seems to meet OG requirements and is enforced properly \\
\hline Management & seems to meet OG requirements and is implemented properly \\
\hline Boysun region (mixed site) \\
\hline Relevance & historic and archaeological site; important landscapes \\
\hline Criteria & ix (+ iv, v and vii) \\
\hline Values & low concern \\
\hline Threats & Low \\
\hline Protection & some concern - no protected area \\
\hline Management & some concern \\
\hline Sarmishsay (mixed site) \\
\hline Relevance & petroglyphs, landscapes, rare animal and plant species \\
\hline Criteria & ix (+ vi) \\
\hline Values & low \\
\hline Threats & high (no protected area) \\
\hline Protection & some concern \\
\hline Management & some concern \\
\hline
\end{tabular}

The information presented in Table 8 stem from various sources, including the results of the three consultation workshops, internet and literature sources. 


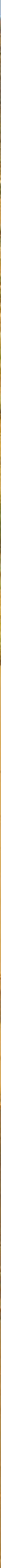




\section{Potential for nomination of World Heritage Sites}

Chapter 4 seeks to evaluate the existing potential of areas and sites for nomination, identified in the literature, studies and inventories, of particular interest and/or importance for biodiversity.

\subsection{IUCN World Heritage thematic studies}

\subsubsection{Regional overview for Central Asia}

Table 9.

Sites suggested as priority natural sites in Central Asia (Source: Magin, 2005).

As mentioned above, the only detailed study on the subject was carried out in and it highlighted the under-representation of WH sites in the region and identified six potential priority natural sites for nomination (Table 9).

\begin{tabular}{|c|c|c|c|c|}
\hline \multirow[t]{2}{*}{ Country } & \multirow[t]{2}{*}{ Site name } & \multicolumn{2}{|c|}{ Criteria } & \multirow[t]{2}{*}{ Observations } \\
\hline & & $\mathrm{ix}$ & $x$ & \\
\hline \multirow[t]{4}{*}{ Kazakhstan } & $\begin{array}{l}\text { Saryarka - Steppes } \\
\text { and Lakes of Northern } \\
\text { Kazakhstan }\end{array}$ & $\checkmark$ & $\checkmark$ & $\begin{array}{l}\text { Inscribed in } 2008 \text { under } \\
\text { criteria (ix) and (x) }\end{array}$ \\
\hline & $\begin{array}{l}\text { Extension of Golden } \\
\text { Mountains of Altai }\end{array}$ & & $\checkmark$ & $\begin{array}{l}\text { Site originally inscribed } \\
\text { in } 1994 \text { (Russian } \\
\text { Federation) under } \\
\text { criterion (x) }\end{array}$ \\
\hline & Western Tien-Shan & $\begin{array}{l}\text { To be verified } \\
\text { by the State } \\
\text { Party }\end{array}$ & $\checkmark$ & $\begin{array}{l}\text { Inscribed in } 2016 \text { under } \\
\text { criterion }(x)\end{array}$ \\
\hline & Northern Tyan-Shan & & $\checkmark$ & $\begin{array}{l}\text { Inscribed in } 2002 \text { under } \\
\text { (x) as "Northern Tyan- } \\
\text { Shan - Ile Alatau State } \\
\text { National Park" }\end{array}$ \\
\hline Kyrgyzstan & Western Tien-Shan & $\begin{array}{c}\text { To be verified } \\
\text { by the State } \\
\text { Party }\end{array}$ & $\checkmark$ & $\begin{array}{l}\text { Inscribed in } 2016 \text { under } \\
\text { criterion }(x)\end{array}$ \\
\hline Tajikistan & Tigrovaya Balka & $\checkmark$ & $\checkmark$ & $\begin{array}{l}\text { Included on TL under } \\
\text { criteria (ix) and (X) }\end{array}$ \\
\hline Turkmenistan & Badhyz & $\checkmark$ & $\checkmark$ & $\begin{array}{l}\text { Included as "Badhyz" } \\
\text { on TL under criteria } \\
\text { (vii), (ix) and (x) }\end{array}$ \\
\hline Uzbekistan & Western Tien-Shan & $\begin{array}{c}\text { To be verified } \\
\text { by the State } \\
\text { Party }\end{array}$ & $\checkmark$ & $\begin{array}{l}\text { Inscribed in } 2016 \text { under } \\
\text { criterion }(x)\end{array}$ \\
\hline
\end{tabular}


Since the publication of the 2005 WH Thematic Study for Central Asia, the following developments have taken place:

- two sites identified in that study have been inscribed on the WH List:49 Saryarka Steppe and Lakes of Northern Kazakhstan (2008) and Western Tien-Shan, as a serial transnational site between Kazakhstan, Kyrgyzstan, and Uzbekistan (2016);

- $\quad$ one was already included on TL: Northern Tyan-Shan/Kazakhstan (2002);

- two more have been included more recently on TLs of the relevant countries: Tigrovaya Balka/Tajikistan (2006) and Badhyz/Turkmenistan (2009).

The extension of the Golden Mountains of Altai (Russian Federation) to key areas in Mongolia, China and Kazakhstan, also identified in the study, has also been supported several times by the WHC (Decision WHC CONF2O3 VIII.A.1; Decision WHC 36COM 7B.25). ${ }^{50}$

A series of sites potentially meeting either criterion (ix) or ( $x$ ) (Table 10) in addition to other criteria falling under 'cultural' classification, were also proposed in the 2005 study, as potential mixed sites. To date, none have been nominated, and only two are currently listed on TLs, though only under cultural criteria (Barrow and Issyk Kul), while one is under no specific criterion (Turkic Sanctuary of Merke).

\begin{tabular}{|c|c|c|c|c|}
\hline \multirow[t]{2}{*}{ Country } & \multirow[t]{2}{*}{ Site name } & \multicolumn{2}{|c|}{ Criteria } & \multirow[t]{2}{*}{ Observations } \\
\hline & & ix & $\mathbf{x}$ & \\
\hline \multirow[t]{4}{*}{ Kazakhstan } & $\begin{array}{l}\text { Barrow with stone ranges of } \\
\text { the Tasmola culture }\end{array}$ & & & $\begin{array}{l}\text { Included on the TL in } 2012 \text { as part of } \\
\text { the "Silk Road", under criteria (ii), (iii), } \\
\text { (iv), (v) and (vi) }\end{array}$ \\
\hline & Cultural landscape of Ulytau & & & \\
\hline & $\begin{array}{l}\text { Palaeolithic sites and } \\
\text { geomorphology of Karatau } \\
\text { mountain range }\end{array}$ & & & \\
\hline & Turkic Sanctuary of Merke & & & $\begin{array}{l}\text { Included on the TL in } 1998 \text { (no } \\
\text { specified criterion) }\end{array}$ \\
\hline \multirow[t]{3}{*}{ Kyrgyzstan } & Burana minaret & & & \\
\hline & SuleymanToo & & & \\
\hline & $\begin{array}{l}\text { Issyk Kul as a cultural and } \\
\text { natural landscape }\end{array}$ & & & $\begin{array}{l}\text { Submitted in } 2004 \text { and withdrawn, } \\
\text { then included on the TL in } 2010, \\
\text { as part of the "Silk Road sites", } \\
\text { Kyrgyzstan, under criteria (ii), (iii), } \\
\text { (iv), (v) and (vi) }\end{array}$ \\
\hline
\end{tabular}

Table 10. Several other sites were identified by various authors in the early 2000s for nomination under criteria (ix) and ( $\mathrm{x}$ ) (Table 11). Since then, two of these sites have been inscribed on the WH List (Saryarka - Steppes and Lakes of North Kazakhstan; Western Tien-Shan) and one is not currently included on the TLs (Ural and Volga River deltas). 
According to Table 10 and in addition to the extension of the Golden Mountains of Altai into Kazakhstan (Katon-Karagai National Park), three sites may have the highest potential for nomination under the biodiversity criteria: Northern Tyan-Shan, Tigrovaya Balka and Badhyz.

\begin{tabular}{|c|c|c|c|c|c|c|c|c|c|c|c|c|c|}
\hline \multirow[t]{2}{*}{ Country } & \multirow[t]{2}{*}{ Site Name } & \multicolumn{2}{|c|}{ Category } & \multicolumn{2}{|c|}{$\begin{array}{c}\text { Biodiversity } \\
\text { Criteria }\end{array}$} & \multicolumn{7}{|c|}{ Source } & \multirow[t]{2}{*}{ Comments } \\
\hline & & $\mathbf{N}$ & M & ix & $\mathrm{x}$ & A & B & c & D & E & $\mathbf{F}$ & G & \\
\hline \multirow[t]{12}{*}{ Kazakhstan } & $\begin{array}{l}\text { Aksu-Zhabagly } \\
\text { State Natural } \\
\text { Reserve (Aksu- } \\
\text { Djabagli) }\end{array}$ & $\checkmark$ & & & & $V$ & $\checkmark$ & & $\checkmark$ & & & & $\begin{array}{l}\text { Inscribed in } \\
2016\end{array}$ \\
\hline & $\begin{array}{l}\text { Northern Tyan- } \\
\text { Shan (Ile-Alatau } \\
\text { State National } \\
\text { Nature Park) }\end{array}$ & $V$ & & & & & & & $\checkmark$ & $\checkmark$ & & $\checkmark$ & \\
\hline & $\begin{array}{l}\text { Altyn-Emel } \\
\text { State National } \\
\text { Nature Park }\end{array}$ & $\checkmark$ & & & & & & & $\checkmark$ & & & & \\
\hline & $\begin{array}{l}\text { Saryarka - } \\
\text { Steppes and } \\
\text { Lakes of North } \\
\text { Kazakhstan }\end{array}$ & $\checkmark$ & & & & $V$ & & & $\checkmark$ & & & $\checkmark$ & $\begin{array}{l}\text { Inscribed in } \\
2008\end{array}$ \\
\hline & $\begin{array}{l}\text { Extension of } \\
\text { the Golden } \\
\text { Mountains } \\
\text { of Altai into } \\
\text { Kazakhstan } \\
\text { (Katon-Karagai } \\
\text { NP) }\end{array}$ & $V$ & & & & & & $\checkmark$ & & & & $V$ & $\begin{array}{l}\text { Site originally } \\
\text { inscribed in } \\
1994 \text { under } \\
\text { criterion }(x)\end{array}$ \\
\hline & $\begin{array}{l}\text { Central Tien- } \\
\text { Shan }\end{array}$ & $V$ & & & & & & & $\checkmark$ & & & & \\
\hline & $\begin{array}{l}\text { Ural and Volga } \\
\text { River deltas }\end{array}$ & $\checkmark$ & & & & & & & $\checkmark$ & & & & \\
\hline & $\begin{array}{l}\text { Barrows with } \\
\text { stone ranges } \\
\text { of the Tasmola } \\
\text { culture }\end{array}$ & & & & & & $V$ & & & & & & \\
\hline & $\begin{array}{l}\text { Cultural } \\
\text { landscape of } \\
\text { Ulytau }\end{array}$ & & & & & & $V$ & & & & & & \\
\hline & $\begin{array}{l}\text { Palaeolithic sites } \\
\text { and } \\
\text { geomorphology } \\
\text { of Karatau } \\
\text { Mountain range }\end{array}$ & & & & & & $V$ & & & & & & \\
\hline & $\begin{array}{l}\text { Turkic Sanctuary } \\
\text { of Merke }\end{array}$ & & $\checkmark$ & & & & $V$ & & & & & & \\
\hline & $\begin{array}{l}\text { Western Tien } \\
\text { Shan }\end{array}$ & & & & & & & & & & & $\checkmark$ & $\begin{array}{l}\text { Serial } \\
\text { transnational } \\
\text { site inscribed } \\
\text { in } 2016 \\
\text { (Kazakhstan, } \\
\text { Kyrgyzstan, } \\
\text { Uzbekistan) }\end{array}$ \\
\hline \multirow[t]{4}{*}{ Kyrgyzstan } & Sary Tchelek & & & & & $V$ & & & $\checkmark$ & & & & \\
\hline & Burana-Minaret & & & & & & $\checkmark$ & & & & & & \\
\hline & Suleyman-Too & & $\checkmark$ & & $\checkmark$ & & $\checkmark$ & & & & & & \\
\hline & Issyk-Kul & & $V$ & & & $V$ & & $\checkmark$ & & & & & $\begin{array}{l}\text { Submitted } \\
\text { in } 2004 \text { but } \\
\text { subsequently } \\
\text { withdrawn }\end{array}$ \\
\hline
\end{tabular}




\begin{tabular}{|c|c|c|c|c|c|c|c|c|c|c|c|c|c|}
\hline \multirow[t]{2}{*}{ Country } & \multirow[t]{2}{*}{ Site Name } & \multicolumn{2}{|c|}{ Category } & \multicolumn{2}{|c|}{$\begin{array}{c}\text { Biodiversity } \\
\text { Criteria }\end{array}$} & \multicolumn{7}{|c|}{ Source } & \multirow[t]{2}{*}{ Comments } \\
\hline & & $\mathbf{N}$ & M & ix & $x$ & $\mathbf{A}$ & B & C & D & E & $\mathbf{F}$ & G & \\
\hline \multirow[t]{2}{*}{ Tajikistan } & $\begin{array}{l}\text { Tigrovaya Balka } \\
\text { State Reserve }\end{array}$ & & & & & $\checkmark$ & & $\checkmark$ & $V$ & & & $\checkmark$ & \\
\hline & $\begin{array}{l}\text { Tajik National } \\
\text { Park (includes } \\
\text { Pamir Alay } \\
\text { region) }\end{array}$ & $\checkmark$ & & & & $\checkmark$ & & $\checkmark$ & $V$ & $\checkmark$ & & & $\begin{array}{l}\text { Inscribed in } \\
2013\end{array}$ \\
\hline \multirow[t]{4}{*}{ Turkmenistan } & $\begin{array}{l}\text { Sunt- } \\
\text { Khasardinsky } \\
\text { Reserve } \\
\text { (Sunt-Hasardag } \\
\text { (Western } \\
\text { Kopetdag) }\end{array}$ & & & & & & & $\checkmark$ & & & & & \\
\hline & Badhyz & $V$ & & $\checkmark$ & $\checkmark$ & $\checkmark$ & & $\checkmark$ & $V$ & & $\checkmark$ & $\checkmark$ & \\
\hline & Kugitang ${ }^{50}$ & $V$ & & & & $\checkmark$ & & $\checkmark$ & $V$ & & $\checkmark$ & & \\
\hline & Kara-bojaz Gol & $\checkmark$ & & $\checkmark$ & & & & $\checkmark$ & $V$ & & $\checkmark$ & & \\
\hline \multirow[t]{3}{*}{ Uzbekistan } & $\begin{array}{l}\text { Chatkals } \\
\text { Reserve } \\
\text { (Tchatkalsky) } \\
\text { (Tien-Shan) }\end{array}$ & 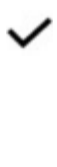 & & & & $\checkmark$ & & $\checkmark$ & $V$ & & & & $\begin{array}{l}\text { Inscribed } \\
\text { in } 2016 \text { as } \\
\text { component } \\
\text { of Western } \\
\text { Tien-Shan }\end{array}$ \\
\hline & $\begin{array}{l}\text { Mountainous } \\
\text { Gissar (Gissar } \\
\text { × Zaravshan } \\
\text { reserves) }\end{array}$ & $\checkmark$ & & & & $V$ & & $\checkmark$ & $V$ & & & & \\
\hline & Kitab & $\checkmark$ & & & & & & $\checkmark$ & & & & & \\
\hline
\end{tabular}

Table 11.

\section{Sites selected as} potential natural and mixed sites in Central Asia (Source: adapted from Magin, 2005).

Categories: $\mathrm{N}$ - natural; $M$ - mixed; Sources:

A - WWF 2005, B

- UNESCO 2002; C - UNESCO 2004, D Karpowicz and Reap, 2002; E - Thorsell and

Hamilton, 2002; F CNPPA, 1982; G - Magin, 2005.

\subsubsection{Potential Priorities for recognition of desert landscapes and geomorphological sites on the World Heritage List}

A study was conducted on this subject in 2011 (Goudie and Seely, 2011). Despite the significant presence of desert and xeric shrubland ecosystems in Central Asia, the overall analysis and the resulting priorities outlined in this report do not involve any of the five Central Asian countries.

As such, this report is only cited by way of reminder.

\subsubsection{World Heritage, wilderness and large landscapes}

According to the IUCN criteria on PAs, ${ }^{52}$ wilderness areas are PAs "that are usually large unmodified or slightly modified areas, retaining their natural character and influence, without permanent or significant human habitation, which are protected and managed so as to preserve their natural condition". The primary management objective of wilderness protected areas is to protect the long-term ecological integrity of natural areas that are undisturbed by significant human activity, free of modern infrastructure and where natural forces and processes predominate; thus, a wilderness may have potential for nomination under criteria (ix) and ( $\mathrm{x}$ ).

$51 \quad$ Also spelled Köýtendag.

52 https://www.iucn.org/theme/protected-areas/about/protected-areas-categories/ category-ib-wilderness-area. 
Large areas that retain high biodiversity and/or important natural processes, and which have a high degree of integrity and are properly protected and managed are becoming scarcer, given that natural habitats are increasingly fragmented and degraded globally. Identifying these areas may therefore facilitate identification and prioritisation of sites for nomination under either criterion (ix) or ( $x$ ).

Initial analyses indicate that many areas of biodiversity interest, including PAs, suffer from a lack of integrity, with the possible exception of strict PAs (SNR) benefiting from a strong protection regime with proper law enforcement and management. However, preliminary scientific studies in Central Asia have identified large landscapes of interest for biodiversity, such as intact forest landscapes (Potapov, 2017), especially in Kazakhstan, being a priori unfragmented and with good integrity (Haddad, 2015), and not subjected to significant human pressure (Ibisch et al., 2016). Such observations could facilitate further work in the future ${ }^{53}$ at national levels to identify new wilderness protected areas having potential for nomination under natural criteria, or expansion of existing sites, for example in the case of the Golden Mountains of Altai.

Tropical and subtropical coniferous forests Temperate grasslands savannas and shrublands

Boreal forests talga Deserts and xeric shrublands Tundra

Montane grasslands and savannas Mediterranean forests woodlands and scrub Tropical and subtropical moist braodleaf forests Temperate coniferous forests Tropical and subtropical grasslands savannas Temperate broadleaf and mixed forests Tropical and subtropical dry broadleaf forests Mangrove Flooded grasslands and savannas

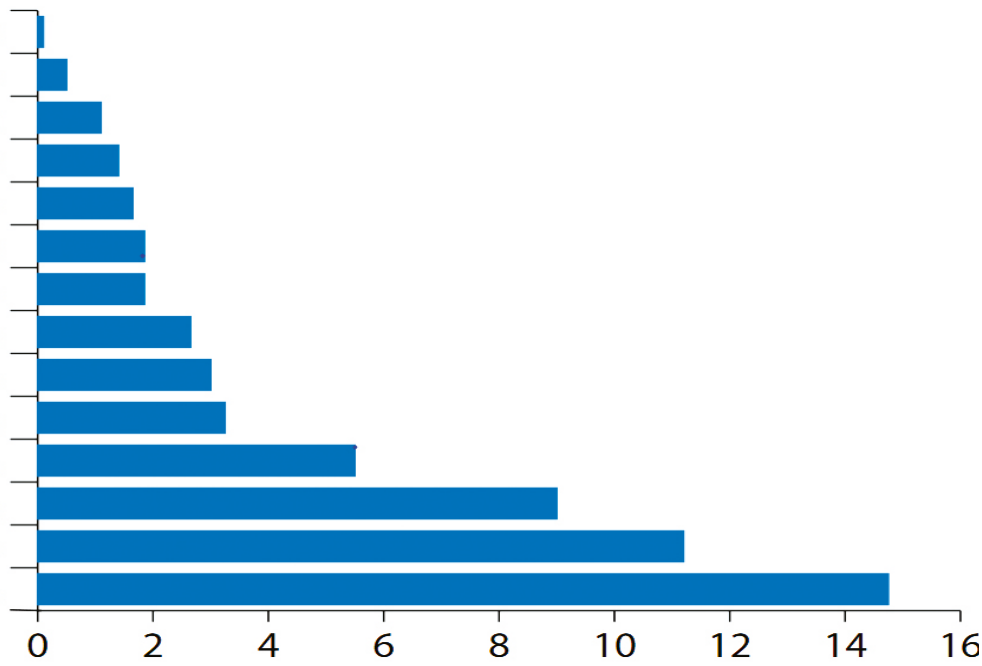

\subsection{Other studies}

Recent literature on the potential for nomination of new WH sites under biodiversity criteria in Central Asia is very scarce. Since the 2005 IUCN thematic study, only a few studies have addressed the subject.

The following paragraphs seek to summarise these findings, supplemented by various sources such as the grey literature, online documents and other publications from various sources.

\subsubsection{Unique nature complexes of Central Asia}

A list of natural complexes selected by experts of the region, in close cooperation with the relevant State Parties' administrations, was recommended in 2005 (WWF Russia, 2005;

53 See also the work in progress under the CADI project that in the near future may lead to the identification of sites having potential in desert ecosystems of Turkmenistan and possibly on the Ustyrt Plateau; both areas look to have good integrity and qualify as "wilderness" (Source: MSF).

54 Desert and xeric shrublands, montane grasslands and savannas and temperate coniferous forests stand out as gaps.

55 Desert and xeric shrublands, montane grasslands and savannas and temperate coniferous forests stand out as gaps.

Figure 4.

Percentage of globalscale wilderness currently protected in natural and mixed World Heritage sites (NWHS), for each of the 14 biomes (Source: IUCN, 2017)..$^{55}$ 
Lysenko, 2007). Several of these complexes are currently represented on the WH List and all others are inscribed on TLS.

From this initial list, six natural complexes (Table 12) seem to offer possibilities for nomination of serial sites, many of which are transnational and/or transboundary. However, the Kugitang and Issyk-Kul sites might no longer be strong cases for nomination under biodiversity criteria, due to their low level of integrity (see below).

\begin{tabular}{|c|c|c|c|c|}
\hline Country & $\begin{array}{l}\text { Name of the } \\
\text { complex }\end{array}$ & $\begin{array}{l}\text { Total surface } \\
\text { area }\left(\mathrm{km}^{2}\right)\end{array}$ & $\begin{array}{l}\text { Name of the protected } \\
\text { areas included }\end{array}$ & $\begin{array}{c}\text { Surface of } \\
\text { protected areas } \\
\left(\mathbf{k m}^{2}\right)\end{array}$ \\
\hline \multirow[t]{13}{*}{ Kyrgyzstan } & \multirow[t]{13}{*}{ Issyk-Kul basin } & \multirow[t]{13}{*}{17,422} & $\begin{array}{l}\text { Issyk-Kul Lake (BZ of } \\
\text { the Issyk-Kul Biosphere } \\
\text { Reserve) }\end{array}$ & 14,571 \\
\hline & & & $\begin{array}{l}\text { Issyk-Kul State Strict Nature } \\
\text { Reserve }\end{array}$ & 198 \\
\hline & & & $\begin{array}{l}\text { Sarychat-Ertashsky State } \\
\text { Strict Nature Reserve }\end{array}$ & 721 \\
\hline & & & Karakol Nature Park & 383 \\
\hline & & & $\begin{array}{l}\text { Malaya Ak-Suu State Forest } \\
\text { Reserve }\end{array}$ & 0,95 \\
\hline & & & $\begin{array}{l}\text { Teploklyuchen State Nature } \\
\text { Monument }\end{array}$ & 321 \\
\hline & & & $\begin{array}{l}\text { Tyup State Nature } \\
\text { Monument }\end{array}$ & 191 \\
\hline & & & $\begin{array}{l}\text { Djeti-Oguz State Nature } \\
\text { Monument }\end{array}$ & 313 \\
\hline & & & $\begin{array}{l}\text { Ken-Suu State Nature } \\
\text { Monument }\end{array}$ & 87 \\
\hline & & & $\begin{array}{l}\text { Djargylchak State Nature } \\
\text { Monument }\end{array}$ & 231 \\
\hline & & & $\begin{array}{l}\text { Barskoon Waterfall } \\
\text { Geological State Nature } \\
\text { Monument }\end{array}$ & \\
\hline & & & $\begin{array}{l}\text { Djetu-Oguz Cliff Geological } \\
\text { State Nature Monument }\end{array}$ & \\
\hline & & & $\begin{array}{l}\text { Terskei Ala-Too, alpine and } \\
\text { subalpine areas (Core zone } \\
\text { of the Issyk-Kul Biosphere } \\
\text { Reserve) }\end{array}$ & 405 \\
\hline Tajikistan & Tigrovaya Balka & 498 & $\begin{array}{l}\text { Tigrovaya Balka State Strict } \\
\text { Nature Reserve }\end{array}$ & \\
\hline
\end{tabular}




\begin{tabular}{|c|c|c|c|c|}
\hline \multirow[t]{10}{*}{ Turkmenistan } & $\begin{array}{l}\text { Syunt- } \\
\text { Hasardag }\end{array}$ & \multirow[t]{2}{*}{64} & $\begin{array}{l}\text { Syunt-Hasardag State Strict } \\
\text { Nature Reserve }\end{array}$ & 26 \\
\hline & & & $\begin{array}{l}\text { Syunt-Hasardag State } \\
\text { Nature Monument }\end{array}$ & 38 \\
\hline & \multirow[t]{4}{*}{ Badhyz } & \multirow[t]{4}{*}{1,447} & $\begin{array}{l}\text { Badhyz State Strict Nature } \\
\text { Reserve }\end{array}$ & 877 \\
\hline & & & $\begin{array}{l}\text { Pulikhatum State Nature } \\
\text { Monument }\end{array}$ & 150 \\
\hline & & & $\begin{array}{l}\text { Kyzyldzhar State Nature } \\
\text { Monument }\end{array}$ & 300 \\
\hline & & & $\begin{array}{l}\text { Chemenabit State Nature } \\
\text { Monument }\end{array}$ & 120 \\
\hline & \multirow[t]{4}{*}{ Kugitang } & \multirow[t]{4}{*}{1,164} & $\begin{array}{l}\text { Kugitang State Strict } \\
\text { Nature Reserve }\end{array}$ & 271 \\
\hline & & & $\begin{array}{l}\text { Karlyuk State Nature } \\
\text { Monument }\end{array}$ & 400 \\
\hline & & & $\begin{array}{l}\text { Khodzhapil State Nature } \\
\text { Monument }\end{array}$ & 316 \\
\hline & & & $\begin{array}{l}\text { Khodhaburdzhibelend State } \\
\text { Nature Monument }\end{array}$ & 617 \\
\hline \multirow[t]{2}{*}{ Uzbekistan } & \multirow[t]{2}{*}{ Gorny Gissar } & \multirow[t]{2}{*}{864} & $\begin{array}{l}\text { Gissar State Strict Nature } \\
\text { Reserve }\end{array}$ & 810 \\
\hline & & & $\begin{array}{l}\text { Kitab State Strict Nature } \\
\text { Reserve }\end{array}$ & 54 \\
\hline
\end{tabular}

Four complexes are already inscribed in TLs under biodiversity criteria, fully or partially: ${ }^{56}$ Tigrovaya Balka, Syunt-Hasardag, Badhyz,,77 and Gissar.

All four complexes have been identified several times in the past as sites with potential for nomination under biodiversity criteria, three have also been identified as potential KBAs (Tigrovaya Balka, Badhyz and Gissar). ${ }^{58}$ According to the consultations conducted during the development of this thematic study, all seem to have maintained significant value:

- Kugitang was previously identified as having potential for nomination (UNESCO, 2002; Karpowicz and Reap, 2002), but the area has not been prioritised by other authors more recently (Magin, 2005 among others) and human pressure on the area has been reported as high; 59 its level of integrity seems to be highly questionable as concluded by the WHC in 2016, when the site was nominated (Decision WHC 40 COM 8B.10); 60

- Issyk-Kul basin is also a controversial area; the basin contains a series of PAs and two potential KBAs; it is also partly covered by a BR and a Ramsar Site. However, the lake and its watershed are under substantial human pressure (Section 4.2.4) and they may very likely not meet the level of integrity required by the WH Convention. Furthermore, this site is currently inscribed on the TL of Kyrgyzstan under cultural criteria only (see Table 10).

56 Issyk-Kul is inscribed under cultural criteria (Silk Roads: Routes Network of the Chang'an-Tianshan Corridor).

57 Also spelled "Badhkyz".

58 http://www.keybiodiversityareas.org/home.

59 http://datazone.birdlife.org/site/factsheet/20586.

60 (http://whc.unesco.org/en/decisions/?id decision=6789\&)
Table 12.

Natural complexes prioritised as having potential for nomination under biodiversity criteria (Source: WWF Russia, 2005). 


\subsubsection{Mountains of Central Asia biodiversity hotspot ${ }^{61}$}

The mountains of Central Asia consist of two major ranges, the Pamir and the Tien-Shan ranges, which spread over $860,000 \mathrm{~km}^{2}$, rising from sea level to over $7,700 \mathrm{~m}$ in altitude, and overlapping the five countries of the region, as well as northeastern Afghanistan and western China. The predominant vegetation types in this region are a mix of deserts and semi-deserts, arid and high steppes, mountain meadows, spruce, fruit and juniper forests, and freshwater wetlands.

A global overview of mountain PAs on the WH List was conducted by IUCN in 2002 (Thorsell and Hamilton, 2002). ${ }^{62}$ In that study, three areas emerged as having strong potential "for consideration for nomination" by the relevant State Parties in the region: Pamir National Park, Tajikistan, which was inscribed on the WH List in 2013; and AksuDjabagly SNR ${ }^{63}$ and Ile-Alatau Nature Park, ${ }^{64}$ Northern Tien-Shan, both included on the Kazakhstan TL in 2002.

A more recent survey outlined the KBAs in the biodiversity hotspot, focused on the priorities for strategic conservation investment potential (CEPF, 2017).

A series of 21 priority sites were selected: four priority sites already inscribed on the WH List as components of the Western Tien-Shan WH property (Bayanbulak and Kaidu River valleys, Tianshan Tien Chi Lake, Aksu Zhabagly, Aflatun Padyshata and Akbulak River basin), and one was deferred by the WHC (Koytendag) (Decision WHC 40 COM 8B10). ${ }^{65}$

An additional 17 sites may, in principal, have potential for nomination under either criterion, alone or in sets of components that may make up one or several comprehensive serial sites, transboundary or not (Table 13).

According to this survey, the sites prioritised include 129 potential Key Biodiversity Areas (KBA) that are still under assessment (Section 4.3.4), of which 62 areas only overlap with PAs. Most KBAs are outside PAs and thus do not currently meet the WH requirements for nomination. State Parties are encouraged to consider designating more KBAs as PAs, thus making the national OA networks more representative and future $\mathrm{WH}$ sites eligible for nomination.

This finding leads to the conclusion that in some cases, it may be necessary to set up new PAs to enable successful nominations for high value areas that are not yet protected, and conversely, that potential for WH nomination should encourage the State Parties to set up new PAs.

Those potential KBAs host a number of species listed as threatened, with 32 priority species considered in the study (Table 14). However, they are relatively small compared to other KBAs in the mountain ecosystem and they are also not among the areas having the highest potential for trigger species (Annexes 6 and 7).

61 https://arquivo.pt/wayback/20091012194139/http://www.biodiversityhotspots.org/xp/Hotspots/central_ asia/Pages/default.aspx.

62 https://portals.iucn.org/library/node/8108.

63 Described in the report as containing " 74 of 16 habitats found in the Tien Shan mountains, an exceptional biodiversity (72 wild relatives of cultivated plants) and extensive forests, and paleontological values with more than 2000 petroglyph".

64 Described in the report as containing "dramatic vegetation gradients within 4,000 m of relief, blend of vegetation types from 2 floristic regions and extensive ice age relic forests".

65 http://whc.unesco.org/en/decisions/?id decision=6789\&. 


\begin{tabular}{|l|l|}
\hline Country & KBA* Code and Name \\
\hline Kazakhstan & $12-$ Aksay \\
& $\begin{array}{l}13-\text { Almaty Nature Reserve } \\
16-\text { Kolsai } \\
18-\text { Narynkol }\end{array}$ \\
\hline Kyrgyzstan & $\begin{array}{l}4-\text { Kassan-Sai } \\
10-\text { Chychkan } \\
20-\text { Isfairam Shakhimardan } \\
23-\text { Alai-Kuu }\end{array}$ \\
\hline Tajikistan & $21-$ Baljuvan \\
& $23-$ Dashtijum \\
& $24-$ Darvaz \\
& $31-$ Ishakhdara \\
\hline Turkmenistan & $2-$ Tallymerjen \\
\hline Uzbekistan & $6-$ Karabau and Dukentsay River Basins \\
& $24-$ Nuratau Ridge \\
& $30-$ Talimarjan Reservoir \\
\hline
\end{tabular}

* still under assessment.

Given the focus on investment priority, the identified sites may not reflect all areas having the highest values for biodiversity in the mountain ecosystem, though, according to the authors, they have been selected "in view to favour existing WH and candidate sites". ${ }^{6}$ Therefore, although not directly identifying sites with potential for nomination, this prioritisation work may facilitate the selection of sites for future nomination, especially under criterion $(x),{ }^{67}$ having in mind that several prioritised areas are either artificial and used for irrigation (e.g. Talimarjan Reservoir), or not yet protected.
Table 13.

Priority sites for CEPF investment not inscribed in the WH List (Source: CEPF, 2017).

Furthermore, other larger mountainous areas not selected in this survey may also be potentially eligible for WH nomination. They should be identified in the future, though this will require intensive additional field work, far beyond the scope and mandate of this desk study.

\begin{tabular}{|l|c|c|}
\hline Country & Number of KBAs & $\begin{array}{c}\text { Number of KBAs overlapping } \\
\text { with PAs }\end{array}$ \\
\hline Kazakhstan & 23 & 17 \\
\hline Kyrgyzstan & 32 & 13 \\
\hline Tajikistan & 35 & 2 \\
\hline Turkmenistan & 3 & 12 \\
\hline Uzbekistan & 36 & 62 \\
\hline TOTAL & 129 & 13 \\
\hline
\end{tabular}

The study also outlines five priority landscapes, covering 25 ecological corridors of biodiversity value, of which 21 are located within the region and two overlap with existing WH properties (Western Tien-Shan and Pamir Alai and Wakhan Mountains). The three other landscapes (Turkestan and Alai Mountains; Khan-Tengri and Tomur Mountains; Dzungaria), include five, four and four potential KBAs, respectively (Table 15).

Several of these very large areas connect with high value areas for biodiversity in Afghanistan and China, but seem to be under significant pressure from agriculture,

\section{Table 14.}

Potential KBAs in the Mountains of Central Asia Hotspot (Source: adapted from CEPF, 2017).

66 Although it is not specified on the basis of which criteria and assets they have been selected (op. cit., p. 118).

67 For further details, refer directly to CEPF (2017). 
forestry, mining and energy activities. As such, their integrity may be questionable and those areas may not fulfil the OG requirements. It was unfortunately not feasible to assess those contexts in greater detail, and this should be done in the future, on a case by case basis at a smaller scale. It is important to note that although some of these areas may lack the integrity to be listed independently on the WH List, they could likely form part of connectivity corridors and buffer zones in the case of future nomination.

\begin{tabular}{|c|c|c|c|}
\hline Countries & Name & Area $\left(\mathrm{km}^{2}\right)$ & No. of potential KBAs \\
\hline $\begin{array}{l}\text { Kyrgyzstan, Tajikistan, } \\
\text { Uzbekistan }\end{array}$ & $\begin{array}{l}\text { Turkestan and Alai } \\
\text { Mountains }\end{array}$ & 24,300 & 5 \\
\hline $\begin{array}{l}\text { Kazakhstan, Kyrgyzstan, } \\
\text { Tajikistan, Uzbekistan }\end{array}$ & Western Tien-Shan* & 35,300 & 22 \\
\hline $\begin{array}{l}\text { Kyrgyzstan, Tajikistan } \\
\text { (+ Afghanistan and } \\
\text { China) }\end{array}$ & $\begin{array}{l}\text { Pamir-Alai and Wakhan } \\
\text { Mountains* }\end{array}$ & 123,500 & 10 \\
\hline $\begin{array}{l}\text { Kazakhstan, Kyrgyzstan } \\
\text { (+ China) }\end{array}$ & $\begin{array}{l}\text { Khan-Tengri and Tomur } \\
\text { Mountains }\end{array}$ & 24,900 & 4 \\
\hline Kazakhstan (+ China) & Dzungaria & 29,500 & 4 \\
\hline
\end{tabular}

* The eco-corridors and selected landscapes overlapping with WH properties.

Table 15. To summarize, the priorities defined in this study can only indirectly contribute to Eco-corridor and identifying new sites for nomination, whereas the landscapes and ecological corridors selected landscapes characteristics for CEPF

investments in the

Mountains of Central Asia Hotspot (Source: CEPF, 2017).

\subsubsection{Conservation potential in cold winter deserts}

The results from an IUCN/SSC database review carried out by IUCN in 2004 recommended Central Asian deserts as having potential for WH nomination (IUCN, 2004). However, little work was done on the subject to confirm the potential OUV of these types of ecosystems in Central Asia, until the additional assessment in 2017 (Schmidt, 2017). The results from these studies are considered below.

The majority of deserts in Central Asia spread over the lowlands of Kazakhstan, Turkmenistan and Uzbekistan. Those deserts are part of the Turanian biogeographic province of the Palearctic realm and belong to the global ecoregion "Central Asian deserts", which is one of the Global 200 priority Ecoregions (Olson and Dinerstein, 2002; Olson et al., 2004; Dinerstein, 2017).

The following desert landscapes can be distinguished in Central Asia:68

- Karakum desert (Turkmenistan);

- Kyzylkum and Sundukli deserts (Uzbekistan);

- Betpak-Dala and Muyunkum deserts, Balhkash region and Ustyurt Plateau (Kazakhstan, Turkmenistan and Uzbekistan).

These "cold winter deserts" 69 are among the most characteristic deserts in the region. They extend from the Caspian Sea to southern Mongolia, and from the foot of the

68 See also the desert typology set up by the CADI (http://cadi.uni-greifswald.de/en/temperate-deserts/ desert-types/).

69 Cold winter deserts (also referred to as temperate/nemoral deserts) are geographically defined in different ways. The most prominent definition is likely the climate classification after Köppen \& Geiger, 1961; Udvardy, 1975 gives a broader definition, including more physiographic features, which is the reference for the classification of UNESCO WH Sites (see also Rachkovskaya, 2003; Schröder, 1998; Schultz, 2005; Shmida et al., 1985; Walter, 1968). 
Tibetan highlands to the steppes of Kazakhstan. They host a large diversity of species and are characterised by high endemism, though their vegetation is significantly sparser than other forms of temperate deserts. ${ }^{70}$ Despite their importance, cold winter deserts are under-represented in the regional and global network of PAs and on the WH List. When benefiting from a relevant protection status, the few existing PAs may be either too small, too fragmented, or not be managed properly, which may hinder site nomination. In addition, several areas may be under significant pressure from extractive industries, among other human disturbances, which may make site integrity questionable.

The 2017 assessment mentioned above characterised eight "priority regions" in terms of habitat diversity (Map 4; Table 16), overlapping at least three different desert types. These also partly overlap with PAs and other areas of biodiversity values, including IBAs and important routes for migratory birds listed under the CMS and AEWA, as well as for other important mammal species, like saiga and kulan.

These priority regions can facilitate further identification of sites having potential for nomination; according to the assessment, "no desert patch alone would fulfil either criterion (ix) and/or ( $x$ )" (Finc, 2017). ${ }^{71}$ This suggests therefore that serial and/or transnational or transboundary sites, combining PAs containing mixed ecosystems, as well as wetlands and oases from two or more countries, might best qualify for nomination under either criterion.

On this basis, at least three PAs may contribute to creating sites having such high potential. If large enough, they may meet the conditions of integrity and have proper management: Ustyurt SNR (Kazakhstan), Altyn Emel NP (Kazakhstan) and Kaplankyr SNR (Turkmenistan).

\begin{tabular}{|c|c|c|c|c|c|c|}
\hline \multirow[t]{2}{*}{$\mathbf{N}^{\circ}$ on the Map } & \multirow[t]{2}{*}{ Name of the region } & \multicolumn{5}{|c|}{ Country } \\
\hline & & 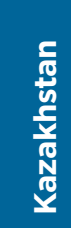 & 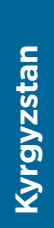 & 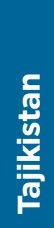 & 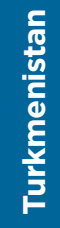 & $\begin{array}{l}\frac{5}{0} \\
\frac{0}{0} \\
\frac{7}{0} \\
\frac{0}{N} \\
\end{array}$ \\
\hline 1 & Western Ustyurt/Mangyshlak & $\checkmark$ & & & & \\
\hline 2 & Northern Ustyurt & $\checkmark$ & & & & $\checkmark$ \\
\hline 3 & Southern Ustyurt & & & & $\checkmark$ & $\checkmark$ \\
\hline 4 & Little Lake Aral/Aralkum Desert/Akpekti & $\checkmark$ & & & & \\
\hline 5 & Central Kyzylkum & & & & & $\checkmark$ \\
\hline 6 & Central Karakum & & & & $\checkmark$ & \\
\hline 7 & Southern Betpak - Dala/Muynkum Desert & $\checkmark$ & & & & \\
\hline 8 & Balkhash & $\checkmark$ & & & & \\
\hline
\end{tabular}

Table 16.

Priority desert regions identified previously (Source: Schmidt, 2017). 70 For future nomination, it will be useful and even necessary to compare this level of endemism in cold deserts
to that of other large deserts worldwide in further detail.

71 Section 5.7, p. 30. 


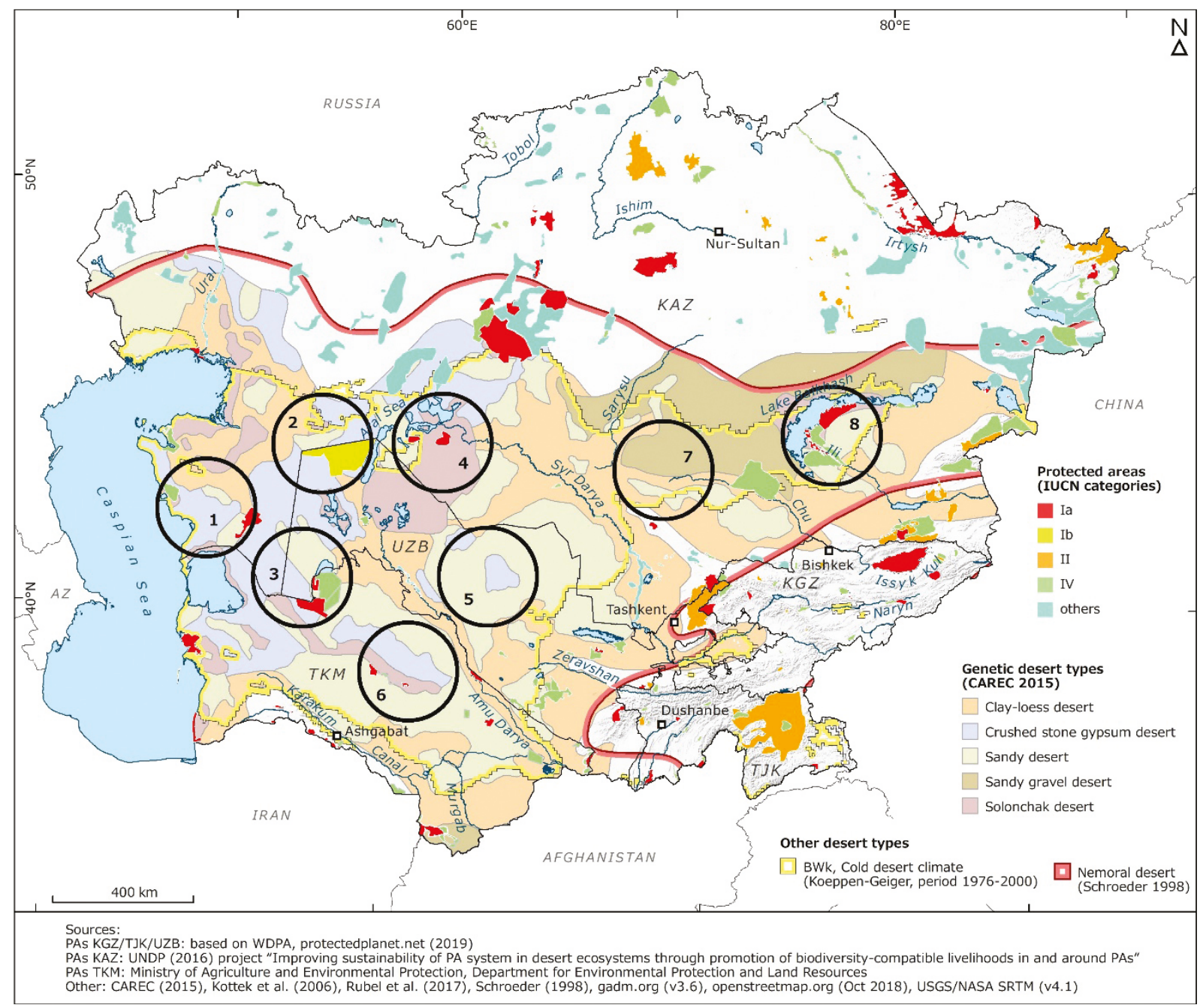

Figure 5. Based on these findings, this report concludes there are two main options:

Priority regions in terms of habitat diversity overlapping at least three different desert types within a reasonable sized territory (c) Michael Succow Foundation (figure modified from Schmidt, 2017).
- a serial transboundary nomination of Middle Asian cold winter desert: Bereketli Garagum SNR (870 km², Turkmenistan) and the Repetek SBR (346 km², Turkmenistan), both located in the southeastern Karakum Desert, when considered together contain high potential for nomination. ${ }^{72}$ The entire area is very remote, overlaps with the only desert currently on the TL of Turkmenistan, and is a good representation of the largest Middle East Asian desert where environmental processes, combined with their size and intactness, are still functioning naturally, which suggests the potential for nomination at least under criterion (ix). Besides its biological interest and value, this area is pristine and sparsely populated. There also appears to be a strong public interest for its proper management. ${ }^{73}$ A serial and transboundary site should be evaluated, centred around those two protected areas, encompassing also the central part of the Kyzylkum Desert (Uzbekistan and Kazakhstan), if extractive industries are not a potential threat.

- a complex of areas representative of the desert biodiversity on the southern Ustyurt Plateau: the Ustyurt Plateau lies in Uzbekistan and Kazakhstan, on roughly 200,000 km² $^{2}$ between the Aral Sea and the Amu Darya River delta in the east, and the Mangyshlak Plateau and the Kara-Bogaz-Gol in the west. This large area consists primarily of stony desert with rich specific flora species ${ }^{74}$ and where many endemic fauna species (e.g.,

72 Repetek is one of the few places in the Karakum Desert where desert forest with black saxaul (Haloxylon aphyllum) have been preserved in the valley shaped depressions (Source: MAB website, 05/02/2019).

73 Source: Michael Succow Foundation pers. comm

74 Rachkovskaya, 1995. 
genera Diplomesodon, Spermophilopsis, Pyderethmus, Allactodipus, Eremodipus, etc.) and the saiga thrive; thus, it may be eligible under criterion ( $x$ ). Poaching, lack of environmental knowledge, and private-sector development have, however, been identified among the main threats affecting the whole area and they might have significant effects on its integrity, which required detailed investigation. The site would be transboundary or serial transnational and would cover the Ustyurt Nature Reserve $\left(2,233 \mathrm{~km}^{2}\right)$ in Kazakhstan and other areas to be determined in Uzbekistan and Turkmenistan.

\subsubsection{Wetlands}

More than 12,000 rivers and 10,000 lakes have been identified (Rustamov, 2018) that may offer - at least in theory - the potential for nomination. However, no comprehensive studies on the value of wetlands of the region have been carried out to date, and no regional/national wetland inventory is available, while literature containing information and data on wetlands is rare.

It is likely that some wetlands, particularly in the eastern part of the Caspian Sea Basin, may offer opportunities for site nomination; several lakes are listed on IBAs and KBAs and several areas have also been designated as Ramsar sites.

The two largest natural lakes in the region, Lake Balkhash and Issyk-Kul Lake, are already inscribed on the TLs of Kazakhstan and Kyrgyzstan respectively, though under cultural criteria:

- following the desiccation of the Aral Sea, Lake Balkhash has become the largest lake of Central Asia with an area of $17,000 \mathrm{~km}^{2}$ (Bragin, 2010); the lly Delta, covering around $8,000 \mathrm{~km}^{2}$, through which $70-80 \%$ of the lake inflow passes annually, is the largest natural delta and wetland complex of Central Asia. This complex is therefore of crucial regional significance for biodiversity (Imentai et al., 2015). It is likely one of the most important wetlands in the region and it overlaps with one IBA. ${ }^{75}$ The overall value and interest of the area for biodiversity were also recognised in 2012 when the Ily River Delta and South Lake Balkhash were designated as a Ramsar Site. However, the lake and its tributary river valleys support three million people spread throughout the area (Dostaj, 2006 in Jungius, 2010) and this complex of wetlands and tugai forest is used for irrigated agriculture, municipalities, and industry. The entire area, with the exception of the southern lake shore, is occupied by small villages and family farms. A new PA was established there in July $2018\left(4,150 \mathrm{~km}^{2}\right)$, with a corridor of ten thousand $\mathrm{km}^{2}$ that is important for connectivity. ${ }^{76}$ An assessment of the integrity of the whole area is first needed, before any nomination;

- Issyk-Kul Lake is a natural water body in a region famous for its natural resources; this lake has long been known as an area having potential for international recognition. A UNESCO BR was established in 2001 and the lake and the adjacent nature reserve were designated as a Ramsar site in 2002. The fauna is characterised by high species diversity and wide distribution over different landscapes. The site was nominated in the early 2000s under biodiversity criteria, and preparatory assistance for its inscription on the WH List was provided by UNESCO in 2003. However, the State Party was invited to reformulate its proposal as a cultural landscape nomination. The site was nominated in 2004 but this nomination was then withdrawn (Decision WHC 29 COM 8B.3). ${ }^{77}$ Bordered by several small towns and villages, the area is an important tourism destination, especially on the north shore, where many

75 KZ 092 (http://datazone.birdlife.org/site/factsheet/ili-river-delta-iba-kazakhstan).

76 Balkhash Lake Strict Nature Reserve (WDPA/PID 14231).

77 https://whc.unesco.org/en/decisions/?id decision=465\&. 
facilities and tourism infrastructure are located. Although the south shore has higher naturalness, it is also under strong human pressures and its ecological integrity may be deemed rather low. Thus, this area should not be prioritised for future nomination under natural criteria.

For sites to be nominated based on the values of wetlands alone, if there are any in the whole region, they still need to be clearly identified and delineated. As such, further field work is required in order to achieve this. For example, Zorkul Lake as part of the Zorkul SNR (Tajikistan), could have also been a candidate for nomination, but the management of this wetland first needs to be significantly improved. It can be expected in the context of natural complexes associating wetlands to several other types of ecosystems, forest and deserts, that sites overlapping wetlands may be identified in the future as having such potential.

The WH property Sayarka - Steppes and Lakes of Northern Kazakhstan, inscribed on the WH List in 2008, already includes wetlands of international importance and associated natural habitats. After consultation with experts and specialists, its extension may offer an excellent opportunity and should be prioritised (see Table 8).

Thus, in general, experts agree that Central Asia contains a high degree of biodiversity and is of great interest from the point of view of natural heritage. However, the potential OUV of this region is often yet to be reflected in the literature. This may be due to difficulties in accessing and generating the relevant data and literature, but certainly does not stem from a lack of environmental interest and natural values of the region.

Given the overall lack of relevant literature, this desk review is not sufficient to compile a comprehensive and well-considered list of priority sites. The following recommendations should therefore be considered carefully, as this is only a step in the comprehensive and complex process of prioritisation of sites having high potential for nomination under criteria (ix) and/or (x).

The next step for the State Parties, in close cooperation with all local stakeholders including scientific universities and organisations, with external support from IUCN as an advisory body for $\mathrm{WH}$ and other expert organisations, should be to assess the current situation of each site on the ground, and determine whether they can adequately meet all WH requirements, in terms of value, protection and management.

\subsection{Prioritisation tools}

A number of tools exist to facilitate and guide the process of prioritising sites for potential nomination. These tools include, but are not limited to, existing PAs and biodiversity related designations. Such areas have been delimited according to rigorous criteria that, although they may not always meet the standards for WH listing, could provide indications as to whether a site offers potential for nomination. These tools are presented below in this regard.

The following analysis is mainly based on the framework used by UNEP-WCMC during the IUCN WH evaluation process, for the comparative analysis of sites nominated under biodiversity criteria (IUCN 2014a). It covers only those prioritisation tools/systems that are relevant for Central Asia - and giving results for the study area.78

78 No "Alliance for Zero Extinction (AZE) site" (http://zeroextinction.org/site-identification/2018-global-azemap/) and "Centre of Plant Diversity' in Central Asia (http://www.biodiversitya-z.org/content/centres-ofplant-diversity-cpd) are currently identified. 


\subsubsection{Global 200 Priority Ecoregions}

In 2002, WWF scientists identified 238 "Global 200 Priority Ecoregions", including 142 terrestrial and 53 freshwater regions (Olson and Dinerstein, 2002). Situated entirely in the Palearctic biome, the Central Asian region encompasses four of the Global 200 Priority Ecoregions, in whole or in part (Table 17 and Map 5). Among them, the "Central Asian Deserts" ecoregion appears to be the only ecoregion that is not currently represented on the WH List.

Table 17.

Natural WH sites currently listed in the four Global 200 Priority Ecoregions overlapping Central Asia (Source: adapted from WWF, 2012)

\begin{tabular}{|l|l|l|}
\hline Number & Priority Ecoregions & WH sites \\
\hline 78 & Caucasus Anatolian Hyrcanian Forests & W7 \\
\hline 79 & Altai Sayan Montane Forests & $\begin{array}{l}\text { Golden Mountains of Altai } \\
\text { Lake Baikal } \\
\text { Uvs Nuur Basin }\end{array}$ \\
\hline 111 & $\begin{array}{l}\text { Middle Asian Montane Steppe and } \\
\text { Woodlands }\end{array}$ & $\begin{array}{l}\text { Xinjiang Tianshan } \\
\text { Western Tien-Shan } \\
\text { Tajik NP }\end{array}$ \\
\hline 134 & Central Asian Deserts & - \\
\hline
\end{tabular}

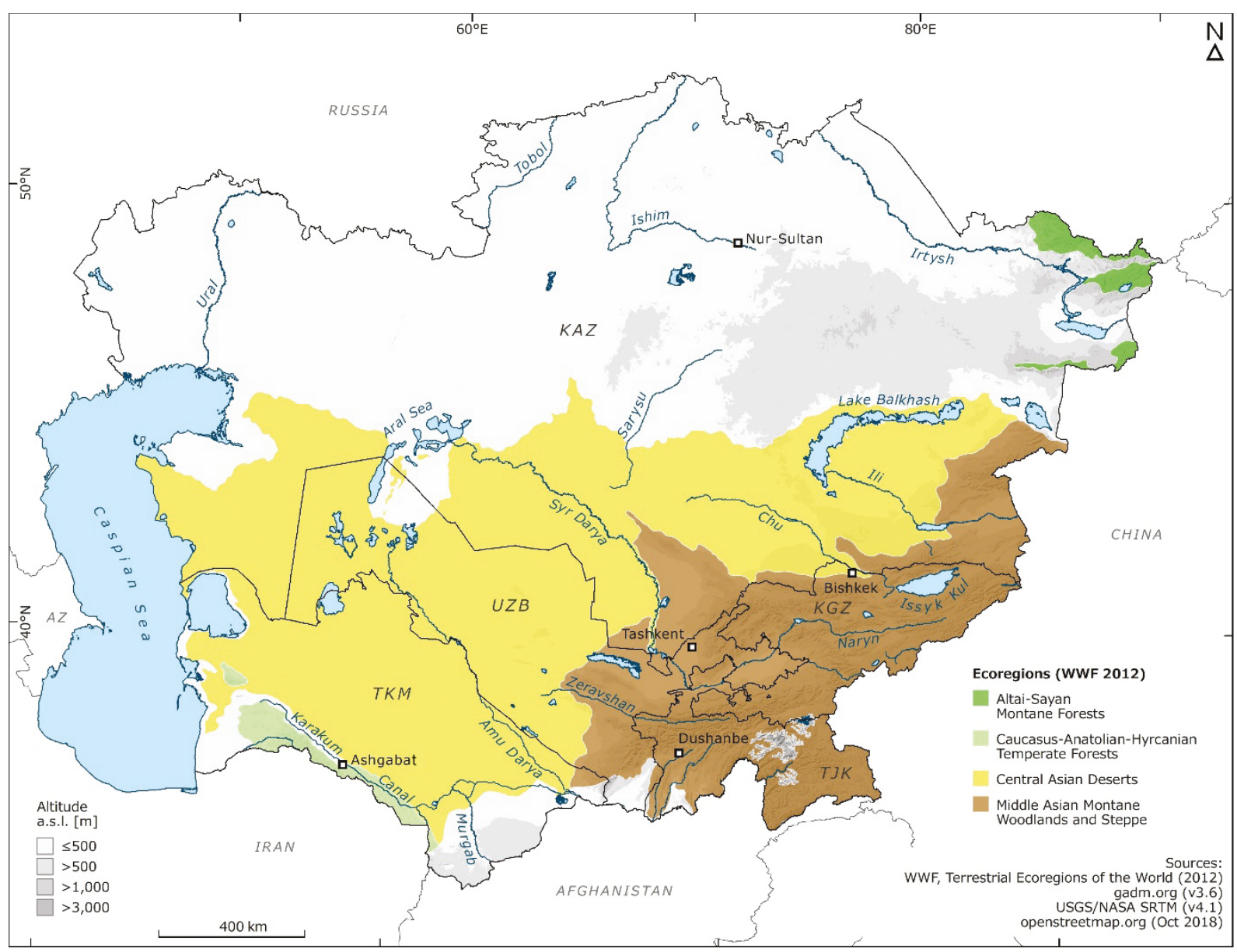

79 This ecoregion is only marginally overlapping Central Asia. The "Hyrcanian Forests" site was nominated by Iran in 2018 and the WH Committee decision will be taken in 2019. Another site named "Colchis rainforests and wetlands" was nominated in that ecoregion by Georgia in 2019; the decision of the WH Committee will be

Figure 6.

The four terrestrial Globa 200 Priority Ecoregions overlapping Central Asia (c) Michael Succow Foundation (figure modified from Olson et al., 2002). 


\subsubsection{Biodiversity hotspots}

The "biodiversity hotspot" concept emerged from scientific literature in the late 1980s, and is still current, aiming to identify and select biogeographic regions with significant levels of biodiversity that are threatened by human activity (Myers, 1988; Myers et al., 2000). ${ }^{80}$ To qualify as a biodiversity hotspot, an area must meet two strict criteria: contain at least 1,500 endemic species of vascular plants found nowhere else on Earth, and have lost at least $70 \%$ of its primary native vegetation.

Worldwide, 36 areas qualify currently as hotspots; they cover 2.3\% of the Earth's land surface and support more than $50 \%$ of the world's endemic species of plants, and nearly $43 \%$ of bird, mammal, reptile and amphibian species.

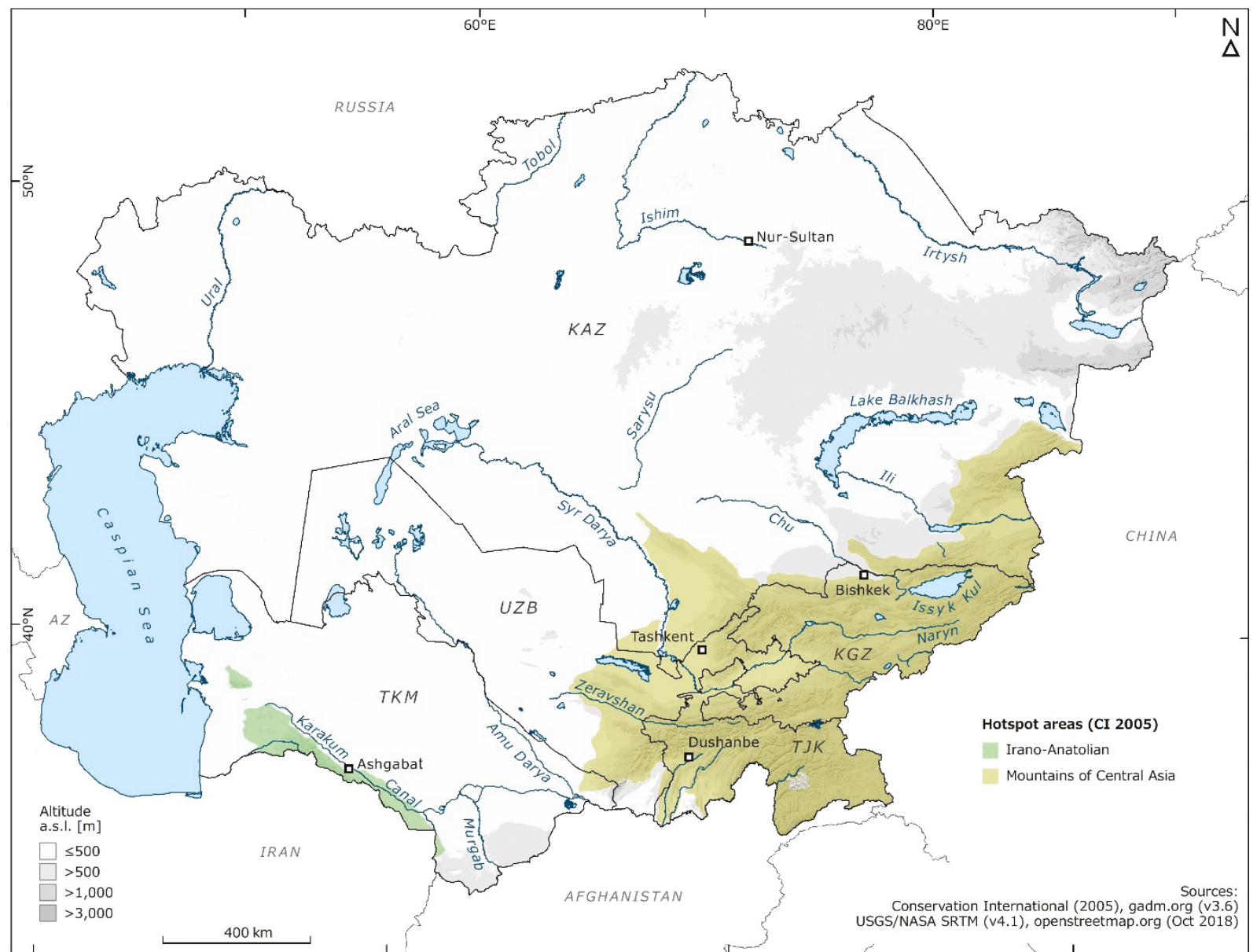

Figure 7. Hotspots cover very large areas, much larger than WH sites, and as such they can be Biodiversity hotspots in

Central Asia (c) Michael Succow Foundation (figure modified from Hoffman et al., 2016) useful indicative areas which may contain a number of sites with potential for nomination.

The Mountains of Central Asia analysed above in detail (section 4.2.2), are one of the currently recognised biodiversity hotspots known to provide crucial ecosystem services for humanity (Map 6).

Those mountains - together with the Irano-Anatolian hotspot covering the Kopetdag range in southern Turkmenistan, shared with Iran and extending far outside the region - are crucial to the maintenance of wild and domesticated biodiversity in Central Asia. They host a wide range of endemic species and natural habitats, including 5,000 to 6,000 vascular plants, 1,500 of which are endemic to the region. The fauna is also impressive,

80 https://doi.org/10.1007/BZ02240252 https://link.springer.com/article/10.1007\%2FBZ02240252\#citeas; https://www.conservation.org/How/Pages/Hotspots.aspx. 
consisting of many species of mammals, birds and reptiles, including several endemic ${ }^{81}$ and/or iconic and threatened species, like the snow leopard.

The Irano-Anatolian hotspot is not represented in the WH List, unlike the Mountains of Central Asia hotspot, which is already represented by two WH properties, Western TienShan and Tajik NP.

\subsubsection{Important Bird Areas}

IBAs ${ }^{82}$ are priority sites for bird conservation because they regularly hold significant populations of one or more globally or regionally threatened, endemic or "congregatory" bird species, or highly representative bird assemblages (Annex 4).

The threshold for IBA designation, however, is much lower than for $\mathrm{WH}$, though the presence of an IBA may contribute in qualifying a site for nomination, especially under criterion ( $\mathrm{x}$ ).

In Central Asia, 258 IBAs have been defined, covering 227,000 km² (Table 18 and Map 7), and these areas host a minimum of 102 globally threatened species of birds.

Of those IBAs, 217 meet either criteria A1 (Globally threatened species), ${ }^{83}$ A2 (Restrictedrange species) ${ }^{84}$ and/or A3 (Biome-restricted species) ${ }^{85}$ of the IBA standard. More than half of these are located in Kazakhstan.

\begin{tabular}{|c|c|c|c|c|}
\hline Country & $\begin{array}{r}\text { Important Bird } \\
\text { Areas }\end{array}$ & $\begin{array}{r}\text { Total surface } \\
\left(\mathbf{k m}^{2}\right)\end{array}$ & $\begin{array}{r}\text { No. of IBAs meeting } \\
\text { criteria A1, A2 and/ } \\
\text { or A3 }\end{array}$ & $\begin{array}{r}\text { No. of globally } \\
\text { threatened species of } \\
\text { birds }\end{array}$ \\
\hline Kazakhstan & 127 & 154,146 & 118 & 27 \\
\hline Kyrgyzstan & 11 & 1,880 & 8 & 17 \\
\hline Tajikistan & 18 & 11,832 & 18 & 16 \\
\hline Turkmenistan & 50 & 34,602 & 44 & 21 \\
\hline Uzbekistan & 52 & 24,628 & 49 & 21 \\
\hline TOTAL & 258 & 227,088 & 217 & 102 \\
\hline
\end{tabular}

The results presented in Table 18 give an overview of each country's ecological value, and for the whole of Central Asia, from the perspective of bird species diversity. It also provides an overall idea of the level of endemism, both at the country and biome levels. ${ }^{86}$

Table 18.

IBAs in Central Asia (Source: Birdlife International IBA's website,

It may also be observed that several sites included currently in the TLs overlap with at least 05/04/2019) one IBA (Altyn Emel; Issyk Kul; Tigrovaya Balka; Zorkul; Amudarya; Badhyz; Koytendag; Hazar and Repetek).

81 Menzbier's marmot, lli pika, etc.

82 http://datazone.birdlife.org/home.

83 The site is known or thought regularly to hold a significant amount of a globally threatened species.

84 The site is known or thought to hold a significant component of a group of species whose breeding distributions define an Endemic Bird Area (EBA) or Secondary Area (SA).

85 The site is known or thought to hold a significant component of the group of species whose distributions are largely or wholly confined to one biome.

86 For more detail, see for Kazakhstan (Sklyarenko et al., 2008; http://datazone.birdlife.org/country/ kazakhstan); Kyrgyzstan (http://datazone.birdlife.org/country/kyrgyzstan); Tajikistan (http://www.birdlife. org/datazone/country/tajikistan), Turkmenistan (Rustamov et al., 2008; http://datazone.birdlife.org/country/ turkmenistan) and Uzbekistan (Ten et al., 2012; http://datazone.birdlife.org/country/uzbekistan). 


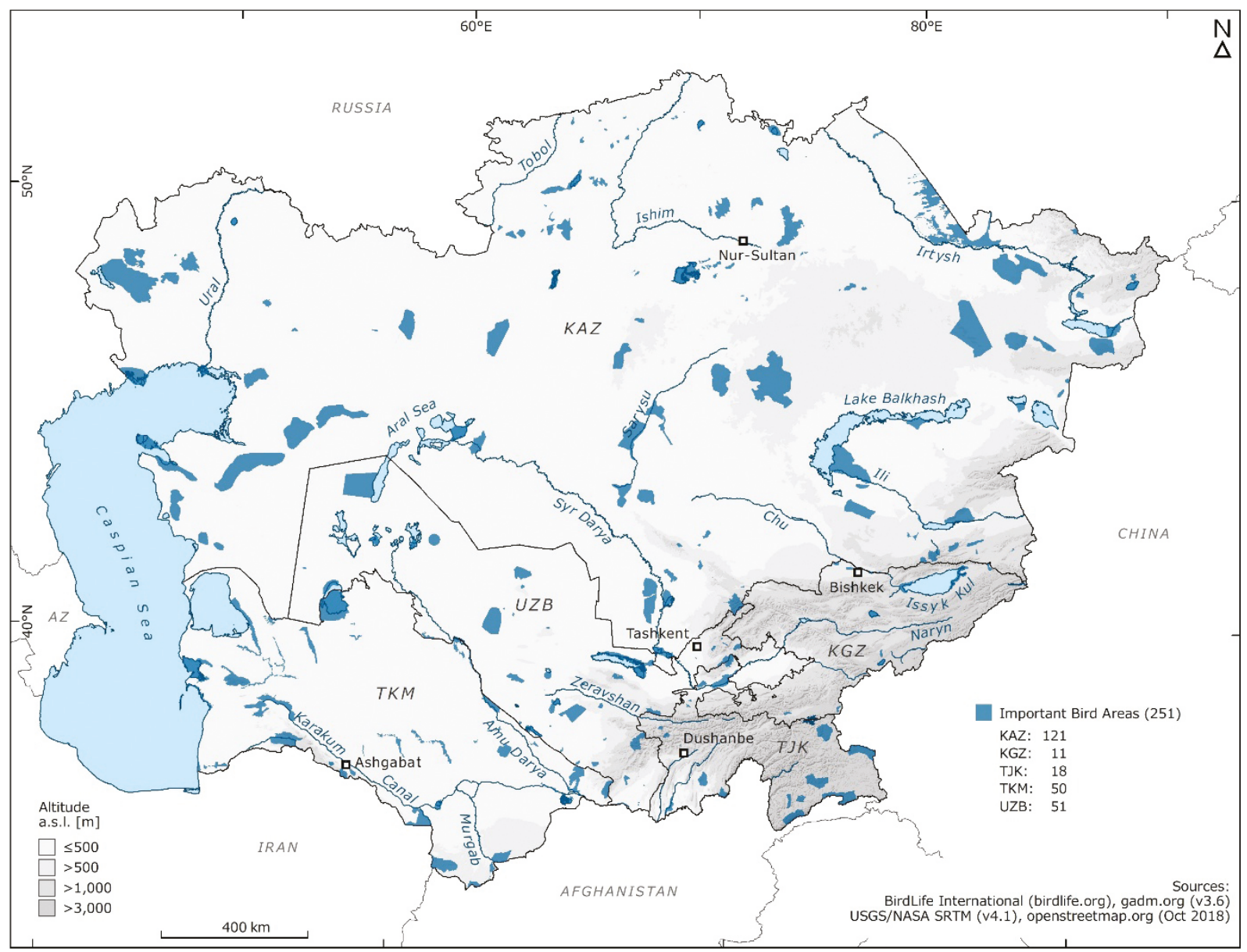

Figure 8.

Important Bird Areas in

Central Asia (c) Michae Succow Foundation (figure

modified from BirdLife International, 2019).

\subsubsection{Key Biodiversity Areas}

As is the case for IBAs, KBAs may help in qualifying a site for nomination under natural criteria.

$\mathrm{KBAs}^{87}$ are areas contributing significantly to the global persistence of biodiversity. They are identified using a set of criteria and thresholds applicable to plants, animals and ecosystems, responding to the $\mathrm{WH}$ Convention obligations and to the $\mathrm{OG}$ requirements under both biodiversity criteria. ${ }^{88}$

More than 250 KBAs are currently listed in the whole region, and many are also listed as IBAs.

Many areas having potential for KBAs have been also recently identified in the Mountains of Central Asia hotspot (See section 4.2.2) (Annex 5); they are situated in Kazakhstan (23), Kyrgyzstan (32), Tajikistan (35), Turkmenistan (3) and Uzbekistan (36) (CEPF, 2017) (Map 8). However, only some are protected. ${ }^{89}$

The KBAs regional inventory is unfortunately far from exhaustive; many areas important for biodiversity, especially in desert and mountain ecosystems, are not yet listed or are still under assessment. Therefore, it is difficult to refer to this inventory to directly identify sites having potential for nomination.

87 http://www.keybiodiversityareas.org/home

88 https://portals.iucn.org/library/sites/library/files/documents/2016-048.pdf.

89 Further details can be found directly in the literature source (https://www.cepf.net/sites/default/files/ mountains-central-asia-ecosystem-profile-eng.pdf). 


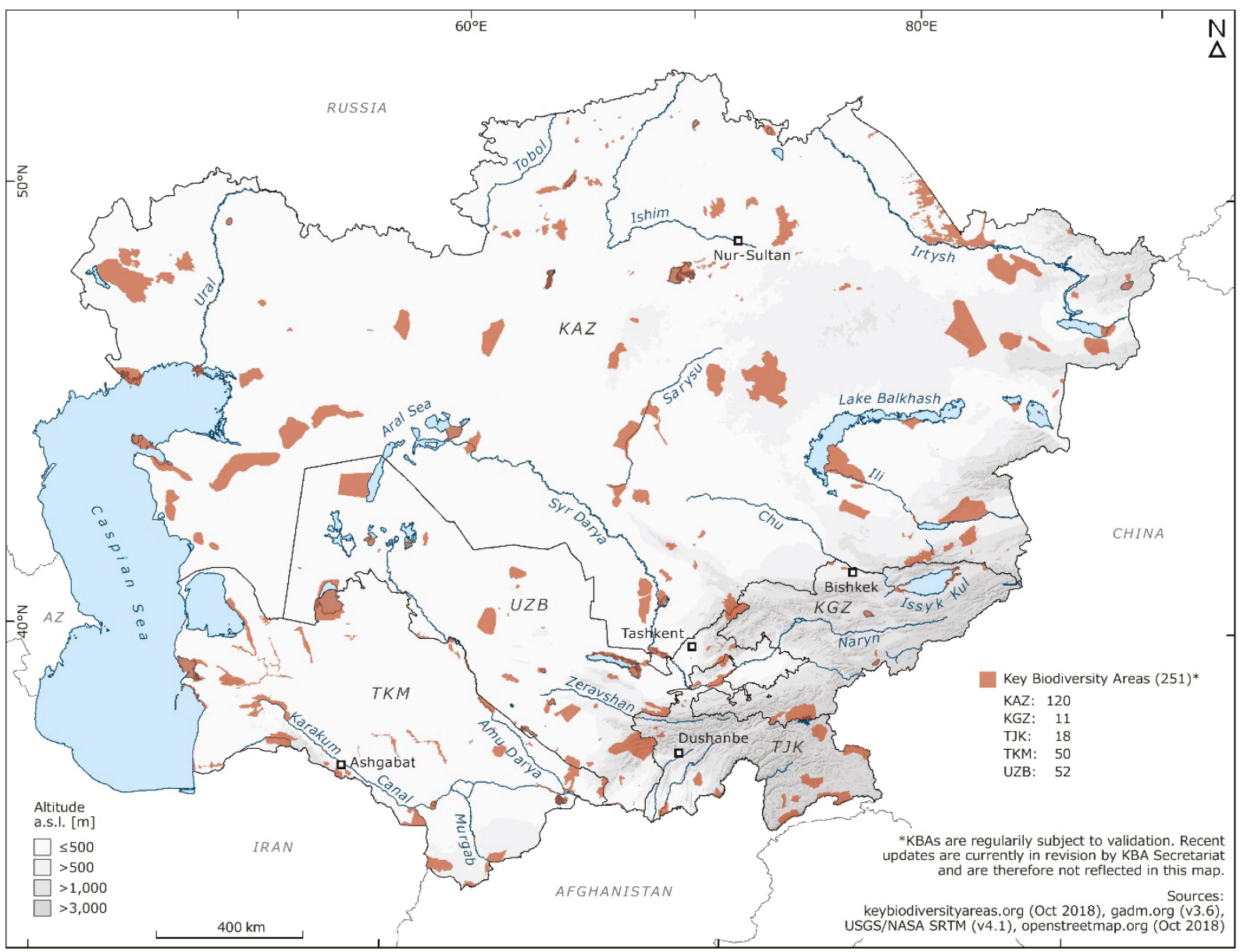

\subsubsection{The most irreplaceable protected areas for mammal, bird and amphibian conservation}

In 2013, researchers assessed the irreplaceability of each of the world's designated and proposed PAs for the conservation of vertebrate species, encompassing all amphibians, non-marine mammals, and birds (Le Saout et al., 2013). "Protected area irreplaceability" was defined as an aggregated measure of the degree of dependence of species on the PA, so that the irreplaceability scores reflect both the number of species in the PA and the degree to which the species present depend on the PA.

The study concluded on an agreement between the most irreplaceable PAs worldwide and those WH properties inscribed under criterion ( $\mathrm{X}$ ), and therefore argued that the irreplaceability scores could be used to identify potential candidate sites for the WH List.

According to this study, no PAs in Central Asia were included among the 100 most irreplaceable protected areas worldwide (IUCN, 2013). However, the detailed data for the five countries of the region shows that five PAs from Central Asia are within the top 1,000 PAs, with regard to one or more irreplaceability scores (Table 19).
Figure 9.

Key Biodiversity Areas in Central Asia (c) Michael Succow Foundation (figure modified from keybiodiversityareas.org, Accessed October 2018). 


\begin{tabular}{|c|c|c|c|c|c|}
\hline Country & Name & $\begin{array}{l}\text { PA } \\
\text { category }\end{array}$ & $\begin{array}{l}\text { Surface } \\
\left(\mathrm{km}^{2}\right)\end{array}$ & $\begin{array}{l}\text { Irreplaceability } \\
\text { highlights }\end{array}$ & Observations \\
\hline \multirow[t]{3}{*}{ Kazakhstan } & Aksu-Dzhabagly & $\begin{array}{l}\text { State } \\
\text { Nature } \\
\text { Reserve }\end{array}$ & 750 & $\begin{array}{l}\text { Among top } \\
\text { 1,000 PAs for } \\
\text { mammals, } \\
\text { threatened } \\
\text { mammals and } \\
\text { all threatened } \\
\text { species }\end{array}$ & $\begin{array}{l}\text { Key species: } \\
\text { Menzbier's } \\
\text { marmot (Marmota } \\
\text { menzbieri) }\end{array}$ \\
\hline & Lepsinskiy & Zakaznik & 2,580 & $\begin{array}{l}\text { Among top } \\
\text { 1,000 PAs for } \\
\text { threatened } \\
\text { amphibians }\end{array}$ & $\begin{array}{l}\text { Key species: } \\
\text { Semirechensk } \\
\text { salamander } \\
\text { (Ranodon sibiricus) }\end{array}$ \\
\hline & Verkhnekoksyiskiy & Zakaznik & 2,400 & $\begin{array}{l}\text { Among top } \\
\text { 1,000 PAs for } \\
\text { threatened } \\
\text { amphibians and } \\
\text { all threatened } \\
\text { species }\end{array}$ & $\begin{array}{l}\text { Key species: } \\
\text { Semirechensk } \\
\text { salamander } \\
\text { (Ranodon sibiricus) }\end{array}$ \\
\hline Kyrgyzstan & Manass & $\begin{array}{l}\text { Wildlife } \\
\text { Refuge }\end{array}$ & 150 & $\begin{array}{l}\text { Among top } \\
\text { 1,000 PAs for } \\
\text { threatened } \\
\text { mammals }\end{array}$ & $\begin{array}{l}\text { Key species: } \\
\text { Menzbier's } \\
\text { marmot (Marmota } \\
\text { menzbieri); } \\
\text { Transborder with: } \\
\text { Chandalash and } \\
\text { Besh Aral (KG); } \\
\text { Ugam Chatkal and } \\
\text { Chatkalskiy (UZ) } \\
\text { and Western Tien- } \\
\text { Shan (KZ and UZ) }\end{array}$ \\
\hline Tajikistan & - & - & - & - & - \\
\hline Turkmenistan & - & - & - & - & - \\
\hline Uzbekistan & Ugam Chatkal & $\begin{array}{l}\text { National } \\
\text { Park }\end{array}$ & 11,492 & $\begin{array}{l}\text { Among top } \\
1,000 \text { PAs for } \\
\text { mammals, } \\
\text { threatened } \\
\text { mammals and } \\
\text { all threatened } \\
\text { species }\end{array}$ & $\begin{array}{l}\text { Key species: } \\
\text { Menzbier's } \\
\text { marmot (Marmota } \\
\text { menzbieri); } \\
\text { Transborder with: } \\
\text { Chandalash, Besh } \\
\text { Aral and Manass } \\
\text { (KG); Chatkalskiy } \\
\text { (UZ) and Western } \\
\text { Tien-Shan (KZ and } \\
\text { KG) }\end{array}$ \\
\hline
\end{tabular}

Table 19. These data suggest the possibility of considering Manass and Ugam Chatkal for potential

Most irreplaceable protected areas in Central

Asia (Source: http:// irreplaceability.cefe.cnrs.fr/ index.htm, 02/04/2019) extension of the Western Tien-Shan WH property in Kyrgyzstan and Uzbekistan. They also lend some support to nominate Aksu-Dzhabagly, inscribed on the TL of Kazakhstan. However, the two other PAs (Lepsinskiy and Verkhnekoksyiskiy) have not previously been identified in the literature as very important sites; their potential needs to be assessed further. 
This methodology is considered in the IUCN guidance on comparative analysis for WH nominations under biodiversity criteria (IUCN, 2014a) but the results of this analysis should be considered with caution due to a number of factors:

- the limited number of taxonomic groups considered;

- the incomplete (especially in Central Asia) and, by now, outdated PA and species information used for the study;

- the fact that the irreplaceability of each PA is largely triggered by a single species;

- the reference only to existing PAs, excluding areas of high biodiversity not yet protected;

- the difficulty of using this methodology for nomination of serial sites, overlapping with several PAs. 


\section{Identification of priority sites for nomination}

\subsection{Prioritisation procedure}

The recommendations that follow likely do not include all sites in the study area having a strong potential for nomination under biodiversity criteria. They reflect a certain level of knowledge that is tentative and should be strengthened in the future to ensure that the selected sites have the highest potential for nomination.

Due to language barriers, all available scientific and technical information have not been considered, though this would have been desirable. Many difficulties also arose during the study because the databases and other sources available on protected areas and sites of significant biological interest in the region are rarely up to date.

However, the sites recommended have appeared repeatedly during the study - as seen in the previous chapters - and over time, whether through the analysis of the literature, or in the discussions with the experts and specialists of the region during the three workshops and throughout the entire consultation process (Table 9). They have been prioritised based on their value, level of integrity, exposure to potential threats, legal regime of protection and effective adequate management, by cross-referencing the available information and data detailed above.

Several sites recommended are serial and/or transboundary. In all cases, the extent of the sites, their component parts and boundaries will need to be more precisely ascertained.

Sufficient attention should be given to the comparative analysis that is required to characterise the OUV of each site nominated; by experience, the quality of these comparative analyses is very often unsatisfactory. There is no unique model for drawing comparisons with properties expressing potentially the same values as the site nominated. State Parties should use the most relevant local information they have and, ideally, design and analyse that best support their justification for nomination. Their first task after defining the combination of potential OUV and related features and attributes, is to ascertain whether this combination of values, features and attributes is already represented on the WH List.

Comprehensive guidance is available in the WH Resource Manual "Preparing World Heritage Nominations" (IUCN, 2011) ${ }^{90}$ and, for further detail, in the IUCN/UNEP "Comparative Analysis Methodology for World Heritage nominations under biodiversity criteria" report (IUCN 2014a).

In summary, the following recommendations should be seen only as an initial assessment and they should be interpreted as a starting point for further analysis. 


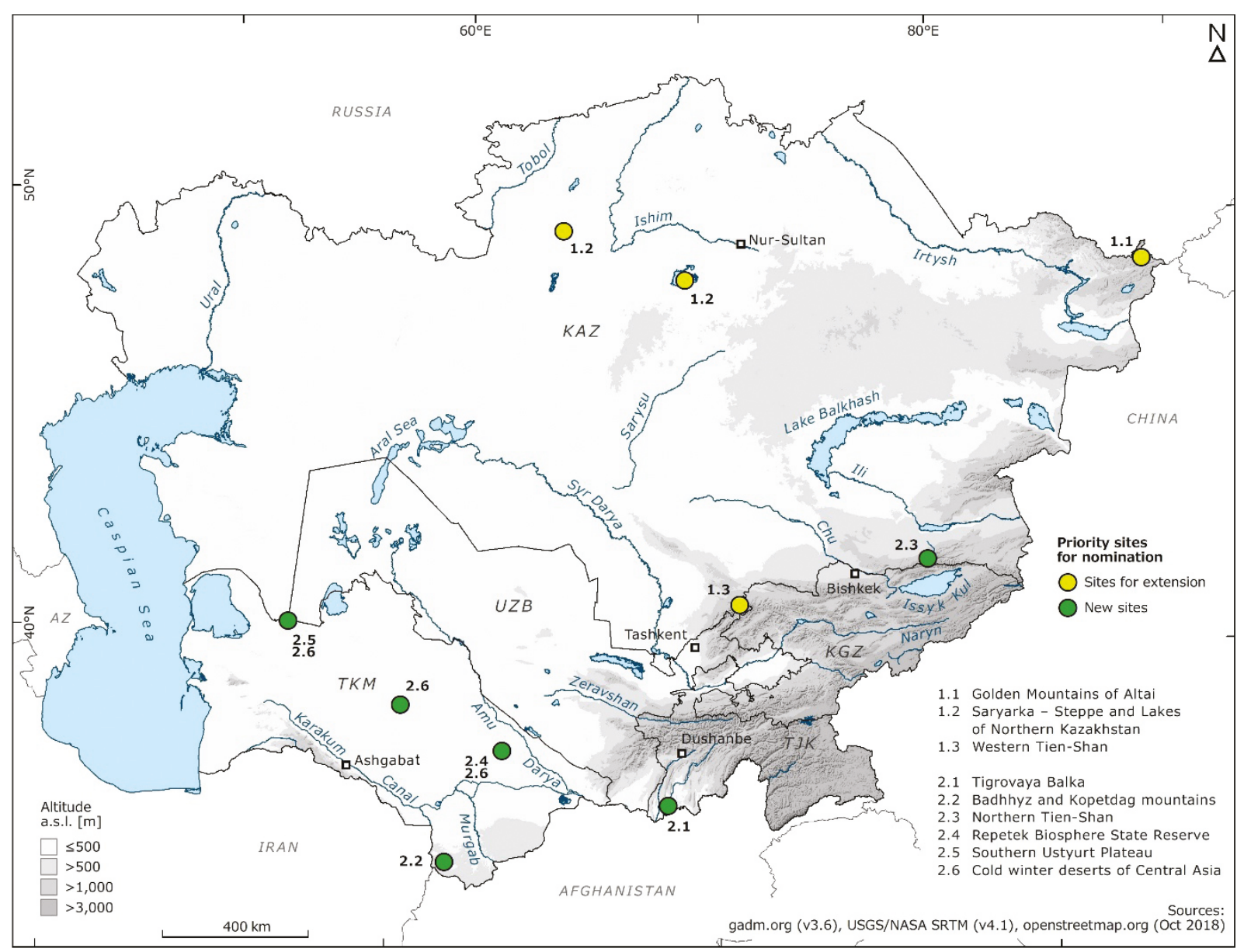

Figure 10.

Priority sites for World Heritage nomination in Central Asia @ Michael

Succow Foundation.

\subsection{Potential candidate sites recommended}

Hereafter, nine priority sites are recommended as having strong potential for nomination under biodiversity criteria (ix) and/or (x) (Table 20; Map 9), in some cases in combination with other natural criteria, (vii) and (viii):

- $\quad$ three sites already inscribed in the WH List that may be extended;

- four sites currently included on TLs;

- two sites not currently included on TLs, one combining other areas recommended for nomination.

Those priorities are not binding for the five States concerned; they should only be viewed as suggestions based on expert opinion built only upon this desk review, to ensure that the outstanding natural heritage of Central Asia will be better represented in the future at the global level, on the WH List. 


\begin{tabular}{|c|c|c|c|c|c|c|c|c|c|c|}
\hline \multirow[t]{2}{*}{ Site } & \multicolumn{5}{|c|}{ Country } & \multicolumn{2}{|c|}{$\begin{array}{l}\text { Year of inscription/ } \\
\text { inclusion }\end{array}$} & \multicolumn{2}{|c|}{ Criteria } & \multirow[t]{2}{*}{ Observations } \\
\hline & KZ & KG & TJ & TM & Uz & WH List & TL & ix & $x$ & \\
\hline \multicolumn{11}{|c|}{ Extension of existing sites } \\
\hline $\begin{array}{l}\text { Golden } \\
\text { Mountains of } \\
\text { Altai }\end{array}$ & $\checkmark$ & & & & & 2006 & & & $\checkmark$ & $\begin{array}{l}\text { inscribed in } \\
\text { the Russian } \\
\text { Federation }\end{array}$ \\
\hline $\begin{array}{l}\text { Saryarka } \\
\text { - Steppe } \\
\text { and Lakes } \\
\text { of Northern } \\
\text { Kazahkstan }\end{array}$ & $\checkmark$ & & & & & 2008 & & $\checkmark$ & $\checkmark$ & \\
\hline $\begin{array}{l}\text { Western } \\
\text { Tien-Shan }\end{array}$ & $\checkmark$ & $\checkmark$ & & & $\checkmark$ & 2016 & & & $\checkmark$ & $\begin{array}{l}\text { potentially for } \\
\text { (ix) }\end{array}$ \\
\hline \multicolumn{11}{|c|}{ Nomination of new sites } \\
\hline $\begin{array}{l}\text { Tigrovaya } \\
\text { Balka }\end{array}$ & & & $\checkmark$ & & & & 2006 & $\checkmark$ & $\checkmark$ & $\begin{array}{l}\text { potentially for } \\
\text { (vii) }\end{array}$ \\
\hline $\begin{array}{l}\text { Badhyz and } \\
\text { Kopetdag } \\
\text { Mountains }\end{array}$ & & & & $\checkmark$ & & & 2009 & $\checkmark$ & $\checkmark$ & \\
\hline $\begin{array}{l}\text { Northern } \\
\text { Tien-Shan }\end{array}$ & $\checkmark$ & & & & & & 2002 & $\checkmark$ & $V$ & \\
\hline $\begin{array}{l}\text { Repetek } \\
\text { State } \\
\text { Biosphere } \\
\text { Reserve }\end{array}$ & $\checkmark$ & & & $\checkmark$ & $\checkmark$ & & 2009 & $\checkmark$ & $\checkmark$ & $\begin{array}{l}\text { included only } \\
\text { on the TL of } \\
\text { Turkmenistan }\end{array}$ \\
\hline $\begin{array}{l}\text { Southern } \\
\text { Ustyurt } \\
\text { Plateau }\end{array}$ & $V$ & & & & $\checkmark$ & & & $V$ & & $\begin{array}{l}\text { potentially for } \\
\text { (vii), (viii) and } \\
(x)\end{array}$ \\
\hline $\begin{array}{l}\text { Cold Winter } \\
\text { Deserts of } \\
\text { Central Asia }\end{array}$ & $\checkmark$ & & & $\checkmark$ & $\checkmark$ & & & $\checkmark$ & & $\begin{array}{l}\text { potentially for } \\
\text { (vii), (viii) and } \\
\text { (x) }\end{array}$ \\
\hline
\end{tabular}

\subsubsection{Extension of sites inscribed on the World Heritage List}

\subsubsection{Golden Mountains of Altai}

The existing WH site is located entirely in Russia and was inscribed on the WH List in 1998, under criterion (x). ${ }^{91}$ Its extension is recommended to include the Katon Karagay NP in Kazakhstan.

\section{Description}

Katon-Karagay NP is located on the eastern edge of the country, in the Southern Altai Mountains. It is the largest national park in Kazakhstan $\left(6,435 \mathrm{~km}^{2}\right)$, sharing a $106 \mathrm{~km}$ of border with the Russian Federation along the existing Golden Mountains of Altai site. The inclusion of this PA will enlarge the overall inscribed area and contribute to maintaining and enhancing the integrity of the whole area.
Table 20.

Sites prioritised for nomination under criteria (ix) and ( $\mathrm{x}$.

91 Which overlaps the Altaisky Zapovednik and a BZ around Lake Teletskoye, Katunsky Zapovednik and a BZ around Mount Belukha, and the Ukok Quiet Zone on the Ukok Plateau. 
The State Parties of Kazakhstan and the Russian Federation have officially approved a transboundary UNESCO BR "Great Altai", which includes Katunsky State Nature Reserve, a component of the existing property, and Katon Karagai BR (Map 9) which overlaps with Katon-Karagay NP. This reserve was accepted in 2017 by the Man and Biosphere International Coordinating Council (MAB ICC).

\section{Justification of Outstanding Universal Value}

Katon Karagay NP has the same environmental and ecological features as the current WH property.

Criterion $(x)$ : inclusion of this PA bordering the current property will strengthen conservation and management of Altai biodiversity; the new transboundary property will enable the expansion of threatened species and their critical habitat areas. It will also consolidate the state of conservation of many rare and endemic fauna species, large ungulates (argali sheep, ibex) and felids, including the globally vulnerable snow leopard; all species having high value for science and conservation.

\section{Integrity}

Its integrity is deemed satisfactory; farming and tourism are the main socio-economic activities.

The current WH property, however, is under human pressure; a project has been planned to build a gas pipeline not been yet routed but which may cross the Ukok Plateau in the future, part of the property. This project represents an ascertained danger to the whole site's OUV and therefore a concern to be noted for its inscription on the List of WH in Danger. A licence has also been granted for gold mining on the same plateau, in close proximity to Lake Teletskoye. Planned and ongoing tourism infrastructure development within the property may also become a concern in the future (Decision WHC 42 COM 7B.75). ${ }^{92}$

Additionally, two other sites (outside of the geographic scope of Central Asia) were identified in the Altai Mountain range, for other potential transboundary extensions of the WH property:

- Highlands of Mongol Altai (Mongolia), included on TL in 2014, under criterion (vii), (viii), (ix) and (x);

- China Altay (China), included on TL in 2010, under criteria (vii), (viii) and (ix).

Those two additional options should be discussed further, between all relevant countries.

\section{Comparison with other similar areas}

The IUCN evaluation report carried out upon the site's nomination (IUCN, 1998) ${ }^{93}$ concluded that "the Altai mountains do not rank as highly as the Caucasus, the Pamirs, the Tien Shan and the Alps. In many respects, they have many significant features and, specifically, have global significance as a centre of plant diversity and as a key location of extensive, undisturbed glaciers of global importance for assessing the impact of global warming on mountain ecosystems. The nominated area also enhances the conservation of globally endangered species such as the Snow Leopard and combine in a relatively small area a high diversity of landscapes features. Finally, there are no existing World

92 https://whc.unesco.org/en/decisions/?id decision=7304\&.

93 https://whc.unesco.org/en/list/768/documents/. 
Heritage sites in this particular biogeographic province... WWF's Global 200 programme also identifies the Altai-Sayan mountain ecoregion as a priority area for conservation".

The site has the same features and characteristics as the existing property, but it would not have an OUV and meet the OGs requirements as a stand-alone nomination.

This recommendation is an extension of the WH property; it should be seen as an improvement of the current context, especially with regard to very threatened species like the snow leopard, which will benefit from this extension and whose conservation is subject to international interest and cooperation. Such a transboundary extension of the existing site may indeed support further transboundary conservation efforts already underway. It would also greatly contribute to the overall integrity of this transboundary site. $^{94}$

This nomination should, however, be evaluated in line with the WHC decision encouraging the State Party to cooperate with neighbouring State Parties, "to undertake a regional comparative biodiversity and geodiversity study of Inner Asian high mountains and deserts ... with a view to developing opportunities for future transboundary potentially serial nominations" (Decision WHC 37COM 8B.14).

\subsubsection{Saryarka - Steppe and Lakes of Northern Kazakhstan}

Extension of this WH property was recommended by the WH Committee to secure habitat for the saiga antelope, and in particular through the Altyn Dala Conservation Initiative. The State Party was encouraged "to consider further extensions of the WH property to contribute toward enhanced protection of this flagship steppe species and related steppe values" and "to expedite extensions of the property already planned, including the additional area of Korgalzhyn State Nature Reserve and an upgraded Sarykopa Wildlife Reserve, as they would add considerable value and increase the functional linkages of the serial property" (Decision WHC 32COM 8B.8). ${ }^{95}$

\section{Description}

This site was identified in 2005 as having high potential for meeting WH criteria (ix) and (x) as well as (vii) and (viii) (Magin, 2005). ${ }^{96}$ However, the IUCN evaluation report, based on the nomination file presented in 2003, concluded that the site did not meet either of the latter two criteria (IUCN, 2003). ${ }^{97}$

Its inscription was initially deferred by the WH Committee in 2004 (Decision WHC 27 COM 8C.6), ${ }^{98}$ prior to adoption in 2008 (Decision WHC 32 COM 8B.8). ${ }^{99}$

Since then, due to a number of factors outlined previously in this report, the status of the saiga antelope and its conservation has shifted. PAs in Kazakhstan are of the now of highest importance for the long-term preservation of this species, given the country harbours the largest population of the species, which only exists elsewhere in smaller numbers in Russia and Mongolia. Altyn Daya State Nature Reserve has now been established, and is the closest southern neighbour PA to the Naurzum Nature Reserve, one component of the WH property. Furthermore, Irgiz Turgai State Nature Reserve has been significantly extended further to the south of the property. All these areas are ecologically connected

\footnotetext{
94 It is important to note that the cultural dimension constitutes a fundamentally important feature of this site.

95 https://whc.unesco.org/en/decisions/1466.

96 p. 22

97 pp. 19-28

98 http://whc.unesco.org/en/decisions/?id decision=701\&.

99 http://whc.unesco.org/en/decisions/?id decision=1466\&
} 
through a $20,000 \mathrm{~km}^{2}$ corridor, contributing to protecting the saiga migration and other ecological processes.

Two options should be evaluated further:

- inclusion of Altyn Dala State Nature Reserve in the WH site; this area covers important habitat for saiga (calving and summer pastures) and will therefore complement the aim of the site to protect saiga habitats and the migration process; both criteria may be applicable as rare fauna and flora species can also be found there. Since 2017, a project of reintroduction of kulan has also been started there;

- inclusion of a larger area to Irgiz-Turgay Reserve which is extremely significant for the saiga antelope of the Betpak-Dala population; this area is used by antelope for calving, rutting, and serves as a hub during its migration. The whole PA consists of two clusters plus Turgay Zakaznik which is internationally recognised as a Ramsar Site and IBA; ${ }^{100}$ this area is also frequently used by saiga. All three PAs are interconnected by an ecological corridor intended to better protect the highly mobile saiga. Inclusion of Irgiz-Turgai Reserve, partly located within the desert biome, according to the Udvardy's classification, will also increase the presence of winter cold deserts in the WH network.

\section{Justification of Outstanding Universal Value}

Both options of extension share the same environmental and ecological features as the current property.

Criterion (ix): this extension will strengthen preservation of substantial steppe and lake areas and largely undisturbed associated environmental processes, among them the saiga migration which will be better preserved.

Criterion ( $\mathrm{x}$ ): it will help strengthen the preservation of steppe and wetlands ecosystems sustaining Central Asian flora and fauna and supporting millions of migratory birds, with substantial populations of many globally threatened species and the critically endangered saiga antelope.

\section{Integrity}

The level of integrity of the PAs that will extend the property is deemed satisfactory, although Altyn Dala has lost a part of its significance as saiga habitat after the mass dieoff in 2015.

\section{Comparison with other similar properties}

The recommended site has the same features and characteristics as the existing $\mathrm{WH}$ property but it would not have an OUV and meet the OG requirements as a stand-alone nomination.

The current WH property was considered by IUCN in its evaluation report, as "including the most important wetland areas in Central Asia" (IUCN, 2008). This extension should be seen an improvement, especially regarding very rare and endangered species, including many migratory bird species and the critically endangered saiga antelope, which will benefit from this extension. It will also respond directly to the WH Committee's recommendations.

100 KZ 042 (http://datazone.birdlife.org/site/factsheet/irgiz-turgay-lakes-iba-kazakhstan). 


\subsubsection{Western Tien-Shan}

\section{Description}

The serial transnational WH property is located in the Tien-Shan mountain system, within Kazakhstan, Kyrgyzstan and Uzbekistan, and consists of 13 component parts drawn from seven protected areas, including:

- Kazakhstan: Karatau State Nature Reserve, Aksu-Jabagly (3 components), and Sairam-Ugam State National Nature Park (3 components);

- Kyrgyzstan: Sary-Chelek State Biosphere Nature Reserve, Besh-Aral State Nature Reserve (2 components), and Padysha-Ata State Nature Reserve;

- Uzbekistan: Chatkal State Biosphere Nature Reserve.

This site was identified in 2005 as having high potential for meeting WH criteria (vii) and (x). Inscribed in 2016 under criterion ( $x$ ) (Decision WHC 40 COM 8B.9), ${ }^{101}$ it may also have potential under (ix) (Magin, 2005; WHC 42 COM 7B.69). ${ }^{102}$

It is recommended that the opportunity of extending the WH property to Manass Wildlife Refuge (Kyrgyzstan) and Ugam Chatkal NP (Uzbekistan), among other PAs, also be assessed, to review its eligibility to criterion (ix) and, lastly, as recommended by the WHC (Decision WHC 42COM 7B.69), to rationalise the existing boundaries and remove components of the property which do not contribute to its OUV.

\section{Justification of Outstanding Universal Value}

As mentioned above and according to the WHC, this property was inscribed under criterion ( $\mathrm{x}$ ), though it may also have potential for inscription under criterion (ix).

Furthermore, the revision of the current boundaries of the components and their BZs should be addressed as a matter of priority; some areas originally included for their palaeontological values which do not contribute substantially to the property's OUV should be excluded, and other areas should be added so as to better follow ecological principles and improve the ecological connectivity between the component parts, thus maintaining and enhancing the property's OUV. The IUCN guidelines on areas of connectivity and transboundary conservation may be helpful in designing the site and its buffer zone, and progressing towards the establishment of adequate legal regimes of protection and management frameworks (IUCN, 2016a).

Criterion (ix): the property may contain large areas of mountain ecosystems and various ecotones with preserved associated biological and ecological processes that should be recognised.

Criterion ( $x$ ): there may be a higher potential in this western part of the chain, around the existing property, that could be better recognised in changing the current property's boundaries.

\section{Integrity}

In its technical evaluation report on the initial nomination, IUCN concluded that information provided by the State Party "remained inconclusive as to the manner in which the serial

101 http://whc.unesco.org/en/decisions/?id decision=6788\&.

102 p. 32; (https://whc.unesco.org/en/decisions/?id decision=7298\& (in its decision the WHC encouraged the States Parties to consider as part of the boundary modification process the potential of the property to also meet criterion (ix), in addition to $(\mathrm{X})$ ). 
property is configured to protect the most important areas with regards to the proposed biodiversity values and how they complement each other in demonstrating Outstanding Universal Value"; there were also "a large number of matters concerning the configuration of component parts, BZs and connectivity that require a substantial amendment to the nomination, in order to meet the integrity requirements of the WH Convention" (IUCN, 2016b). ${ }^{103}$ Despite this, the site was inscribed on the WH List (Decision WHC 4OCOM 8B.9).

The modification of the current property should thus contribute to improving the site's configuration so as to meet at best the $O G$ requirements (Section 78) for integrity and management. Its extension will enhance its OUV and should also be seen as an improvement of the current context, regarding the preservation of threatened species and their habitats, but also for the maintenance of the ecological processes upon which those species depend and which, themselves, contribute to building up the site's value. Lastly, it will be also a direct response to the WHC's recommendations.

\section{Comparison with other similar areas}

The new WH site will have the same features and characteristics as the existing property; it should be compared in priority with other areas from the same broad-scale global conservation priorities areas, inscribed either on the WH List (Xinjiang Tianshan) or on the TLs (Aksu-Zhabagly State Natural Reserve; Amudarya State Nature Reserve; Boysun; Dinosaurs and Caves of Koytendag; Fann Mountains; Gissar Mountains; Hazar State Nature Reserve; Mountains of the Western Tien Shan; Northern Tyan-Shan (Ile-Alatau SNNP); Palaeolithic sites and geomorphology of Karatau; Repetek State Biosphere Reserve; Sarmishsay; Shokhimardon; Altyn-Emel State National Nature Park; Syunt Hasardag State Nature Reserve; Turkic Sanctuary of Merke; Zaamin Mountains and Zakaznik Kusavlisay).

\subsubsection{Nomination of new sites}

\subsubsection{Tigrovaya Balka}

\section{Description}

This site was identified in 2005 as having high potential for meeting criteria (ix) and ( $x$ ) (Magin, 2005) ${ }^{104}$ and was included on the TL of Tajikistan in 2006.105

The reserve is a strictly protected state-owned property (IUCN PA Category 1a). It is a large flat area situated in the Vakhsh River valley, at the confluence with the Panj River where they form the Amu Darya River, near the Afghani border.

Its territory covers an area of $460 \mathrm{~km}^{2}$, extending over $40 \mathrm{~km}$ from southwest to northeast. The reserve is composed of a series of floodplain terraces covered by alluvial soils and has long been considered one of the most important PAs in the region, comprising tugai riverine forests with very specific biodiversity in the valley. The name "Tigrovaya Balka" means Tiger Gorge in Russian, and the Caspian tiger historically inhabited this area. Many other rare, endemic and/or specialised species are also found in the reserve (Kvartalnov, 2011 among other publications).

103 . https://whc.unesco.org/en/list/1490/documents/.

104 p. 24.

105 https://whc.unesco.org/en/tentativelists/2108/. 
Various other ecosystems can also be found within the area, such as semi-desert landscape represented within the hilly range of the Kashkakum Mountain massif, submontane low grassy semi-savannahs and shibliak widespread at the Buritau peak and in the HodjaKaziyon Mountains, and water reservoirs and other types of wetlands. ${ }^{106}$

It is an IBA ${ }^{107}$ and has the potential for being listed as a KBA. ${ }^{108}$

\section{Justification of Outstanding Universal Value}

Tigrovaya Balka is considered the most important PA in Tajikistan, in terms of ecosystem diversity and values for species.

It is situated within the Global 200 Priority Ecoregion "Middle Asian Montane Woodlands and Steppes", represented on the WH List by Xinjiang Tianshan and Western Tien Shan. ${ }^{109}$ However, this reserve bears features that are distinct from those two properties, and it contains the largest and most intact tugai forest massif in Central Asia.

Criterion (ix): the reserve hosts various ecological units, not only tugai lowland forests, but also steppe and semi-desert areas and their various ecotones where many stenoeceous species of flora are found; more than 160 species of birds have also been recorded there, of which 17 were included in the Red Data Book of Tajikistan (1988) and about 70 species breed in the site.110 The reserve supports an important population of Bukhara deer and a number of endemic plant populations. It is influenced by very specific environmental processes directly related to the particular and diverse climatic conditions.

\section{Integrity}

Moderate to intense droughts have occurred in recent times due to the absence of flooding in spring and summer following flow regulation of the Vakhsh River by the Rogun Dam. Pesticide pollution from farming activities and climate change (decreasing trend in overall water discharge from the Fedchenko and Abramov glaciers) may also affect the integrity of the site.

\section{Comparison with other similar areas}

The particular suite of ecological characteristics of the reserve should be carefully analysed in the comparative analysis, especially with the WH properties from the same ecoregion (Xinjiang Tianshan, Western Tien Shan, and Tajik NP), and with other wooded areas and steppe ecosystems from the same broad-scale global conservation priorities areas, particularly those inscribed on TLs (Aksu-Zhabagly State Natural Reserve; Boysun; Fann Mountains; Gissar Mountains; Dashti Djum State Reserve; Zaamin Mountains; Northern Tyan-Shan/Ile-Alatau SNNP) and with other gallery forests globally.

106 For further details: https://whc.unesco.org/en/tentativelists/2108/and Magin (2005), 22-24 pp.

107 TJ 009 (http://datazone.birdlife.org/site/factsheet/tigrovaya-balka-nature-reserve-iba-tajikistan).

108 Currently under assessment (CEPF, 2017).

109 Tajik NP is inscribed only under criteria (vii) and (viii).

110 http://datazone.birdlife.org/site/factsheet/tigrovaya-balka-nature-reserve-iba-tajikistan. 


\subsubsection{Badhyz and Kopetdag Mountains ${ }^{111}$}

\section{Description}

Badhyz was identified as having high potential for meeting WH criteria (ix), (x) and (vii) (Magin, 2005), ${ }^{112}$ and in 2009, it was included on the TL of Turkmenistan, as "Badhyz State Nature Reserve", under those three criteria. ${ }^{113}$

The site encompasses plateau, hilly and lowland landscapes, in the foothills of the Eastern Kopetdag Mountains. Therefore, given its overlap with the Kopetdag Mountains, however marginal, it is suggested that this area be renamed the Badhyz and Kopetdag Mountains.

As inscribed on the TL, the site covers a series of four adjacent state-owned PAs, totalling an area of 1,447 $\mathrm{km}^{2}$ :

- $\quad$ Badhyz State Nature Reserve $\left(877 \mathrm{~km}^{2}\right)$;

- Pulikhatumskiy State Sanctuary $\left(150 \mathrm{~km}^{2}\right)$;

- Kyzyljarskiy State Sanctuary $\left(300 \mathrm{~km}^{2}\right)$;

- Chemenabitskiy State Sanctuary $\left(120 \mathrm{~km}^{2}\right)$.

The area is a mix of plateau, abrupt cliffs, springs, hills and low landscapes, extending in elevation from 200 to $1,000 \mathrm{~m}$. The climate is arid, though more humid than in the typical desert, generally with high winds.

Badhyz State Reserve and the surrounding sanctuaries were established in 1941 for conservation and restoration of the native population of kulan.114 It is also Eurasia's largest natural pistachio (Pistacia badhysi) forest, covering over $400 \mathrm{~km}^{2}$.

This is considered one of the most spectacular nature reserves in Central Asia, hosting the Persian leopard and various large ungulates from the region (e.g.: goitered gazelle, wild goat, urial).

\section{Justification of Outstanding Universal Value}

The area is one of the "Unique Nature Complexes" of Central Asia. The recommended site combines unique natural features: relict pistachio savannas, ancient extinct volcanoes, brackish seasonal lakes, rocky, sandy and other types of deserts and semi deserts. It also harbours a significant number of endemic and threatened flora and fauna species.

Criterion (ix): Badhyz belongs to the "cold winter desert" biome, which is not currently represented on the WH List. It is part of the Turanian Biogeographic Province, also currently unrepresented in the WH List and is considered as the best-preserved natural arid grassland ecosystem in Central Asia. The site is also sufficiently large to maintain and support ecological processes, such as speciation and succession, as well as wildlife migration.

Criterion (x): Iying very near the junction of two priority Global 200 Ecoregions, the Caucasus-Anatolian-Hyrcanian Temperate Forest and the Central Asian Desert - the latter currently unrepresented in the WH network - Badhyz contains many key species associated with both regions, with a high number of endemic plant species. It once also hosted significant populations of many flagship, threatened, large ungulate species,

$111 \quad$ https://whc.unesco.org/en/tentativelists/5432/.

112 p. 22.

113 https://whc.unesco.org/en/tentativelists/5432/.

114 There were around 650 individuals in the early 2000s (Moehlman, 2002); the 2013 estimate was 420 individuals and may even be lower (https://www.iucnredlist.org/species/7951/45171204\#population). 
including kulan, urial, goitered gazelle and Turkmen wild goat, and a small population of Persian leopard, and thus represents an important site for in situ conservation of threatened species and biological diversity.

This is an IBA ${ }^{115}$ that supports a unique complex of bird species and is an important area for threatened raptor species, and a breeding area for numerous globally threatened and near threatened bird species such as Egyptian vulture (EN), Saker falcon (EN) and Lesser kestrel (LC), and a wintering area for the Steppe and Eastern imperial eagles (VU). Many of these raptors nest in the pistachio groves and on the steep cliffs, which also provide breeding habitat for passerines, and for some species, this is the only site of presence in Central Asia.

Criterion (vii): the complex of savannah landscapes and rolling hills provides the area with exceptional natural beauty and aesthetic importance, which might support its inscription under this criterion.

\section{Integrity}

The area is large enough to sustain key species populations and their habitats.

The legal regime of protection seems adequate; however, the management of the area might be weak and not fully appropriate. Livestock and settlements may also potentially threaten the site's values and integrity.

\section{Comparison with other similar areas}

Badhyz has no equivalent in Central Asia in terms of globally threatened mammal diversity and size of populations. The extensive coverage of pistachio woodlands in such concentrations on one site is also exceptional. Most similar sites from the region - with the possible exception in Altyn-Emel (Kazakhstan) which may be recommended to become a component of Northern Tien Shan (Section 5.2.3) ) $^{116}$ - have only much smaller, introduced kulan populations.

The only other natural WH site in Central Asia comparable to Badhyz (i.e. Saryarka Steppes and Lakes of Northern Kazakhstan) is situated much farther north, at the steppe/ northern boreal forest interface, and it has completely different ecological and biological characteristics, and therefore very different fauna and flora composition and diversity.

It might be useful to compare the site globally to other savannas worldwide that host ungulates.

\subsubsection{Northern Tien Shan ${ }^{117}$}

\section{Description}

The area was identified as having high potential for meeting criterion (x) (Magin, 2005),"118 and it was included on the TL of Kazakhstan, as Northern Tian-Shan (Ile-Alatau State National Natural Park), in 2002. ${ }^{119}$

115 TM 038 (http://datazone.birdlife.org/site/factsheet/badhyz-iba-turkmenistan)

116 This should be assessed in further detail, based on the most up to date field information.

117 https://whc.unesco.org/en/tentativelists/1681/.

118 p. 34

119 https://whc.unesco.org/en/tentativelists/1681/. 
As included in TL, the site encompasses three PAs, all of which are state-owned lands:

- Alma Atinskiy State Nature Reserve, established in 1961 and covering an area of 733 $\mathrm{km}^{2}$ and containing an IBA; ${ }^{120}$

- $\quad$ le-Alatau State National Nature Park, established in 1996 and covering an area of roughly $2,000 \mathrm{~km}^{2}$. It is located on the northern slopes of the Zailiysky Alatau massif, Northern Tian Shan physical geographical province;

- Altyn-Emel State National Nature Park' ${ }^{121}$, set up in 1996; the park encompasses an area of $1,700 \mathrm{~km}^{2}$ and was established as a Biosphere Reserve in 2017. It contains an $\mathrm{IBA}^{122}$ and comprises various ecosystems, such as deserts, riparian forests, deciduous and spruce forests, as well as salt marshes and floodplains in the lli River valley.

The entire site will cover around $4,000 \mathrm{~km}^{2}$ and contain a wide spectrum of diverse ecosystems, from low to high elevations, supporting relatively high biodiversity with endemic plants and rich fauna, including the snow leopard and kulan.

\section{Justification of Outstanding Universal Value ${ }^{123}$}

Lying within the "Middle Asian Montane Woodlands and Steppes" Global 200 Priority Ecoregion that is already represented by three WH properties (Tajik National Park (Mountains of the Pamirs); Xinjiang Tianshan and Western Tien-Shan), the area is also near the border of the "Central Asia Deserts" Global 200 Priority Ecoregion which is currently not represented on the WH List (Table 17).

Criterion (ix): the area is a good example of mixed ecosystems and their ecotones, comprising deserts, deciduous and spruce forests, riparian forests and floodplains, and salt marshes. It covers important environmental gradients and ecotones, illustrating several environmental processes, including altitudinal succession.

Criterion ( $x$ ): the area also hosts rich and rare flora communities with a high number of threatened species, many endemic to the country and to the Pamir Tian Shan Highlands biogeographical province, which however is already represented on the WH List by two WH properties (Western Tien Shan and Tajik NP) (Table 1). Altyn Emel SNP hosts the fourth largest population of kulan in the world, estimated currently at around 2,5003,000 animals (Plakhov et al., 2012).

Other criteria: the presence of historical and cultural heritage (petroglyphs, burial mounds, medieval sites, etc.) will require further assessment. Altyn Emel is well known for its cultural features and heritage (archaeological monuments) and may also meet criteria (vii) and (viii).

\section{Integrity}

- Alma Atinskiy is a mountainous area, forming part of northern ridge of the Tien Shan mountains including the northern Zailiisky Alatau and Illissky depression. As an SNR, its protection regime is adequate. The area is not exposed to significant threats and its integrity seems satisfactory;

- $\quad$ le-Alatau is also a mountainous and harsh landscape, stretching from a few hundred to around $5,000 \mathrm{~m}$ in altitude, offering many alpine and sub-alpine landscapes

$120 \mathrm{KZ} 099$ (http://datazone.birdlife.org/site/factsheet/almaty-state-nature-reserve-iba-kazakhstan).

121 See: https://whc.unesco.org/en/tentativelists/1682/.

122 KZ 101 (http://datazone.birdlife.org/site/factsheet/altyn-emel-national-park-iba-kazakhstan).

123 For more detail, (Magin, 2005: 32-34). 
with glaciers, moraines and other erosive reliefs, stone falls, gorges and deep river valleys. Its flora and fauna are typical of the Northern Tien Shan massif, with high diversity representative of the zonation of the area. This area is also subject to low anthropogenic pressure and seems to meet the intactness requirements;

- Altyn-Emel is inscribed on the TL under criterion (ix) and may also meet criterion $(\mathrm{X})$; it also benefits from a good protection and management regime. Its integrity seems satisfactory, with a very low level of threat although a resident population of about 4,000 inhabitants live there engaged in agriculture and cattle rearing, as well as ecotourism and recreational tourism.

In conclusion, the site's integrity will be globally satisfactory; recreational and tourism activities may cause only potential low threats, which however require appraisal in greater detail during the preparation phase of nomination.

\section{Comparion with other similar areas}

The area should first be compared to Xingjiang Tianshan (China) and to other WH properties from the same Global 200 Priority Ecoregions in Central Asia, Western TienShan and Tajik National Park (Mountains of the Pamirs). It should also be compared to other sites inscribed on TLs from the same broad-scale global conservation priorities areas (Aksu-Zhabagly State Nature Reserve; Badhyz State Nature Reserve; Boysun; Dinosaurs and Caves of Koytendag; Fann Mountains; Gissar Mountains; Sarmishsay; Shokhimardon; Dashti Djum State Reserve; Syunt Hasardag State Nature Reserve; Tigrovaya Balka; Zaamin Mountains; Zakaznik Kusavlisay and Zorkul State Reserve).

\subsubsection{Repetek State Biosphere Reserve}

\section{Description}

Established in 1927, Repetek State Reserve is one of the oldest reserves in Turkmenistan, encompassing an area of approximately $346 \mathrm{~km}^{2}$. It was designated as a Biosphere Reserve in 1978, and included on the TL of Turkmenistan in 2009.124 The reserve is situated in the southeastern Karakum Desert and it overlaps with an important IBA. ${ }^{125}$ It is also one of the few natural desert sites in Central Asia with large coverage of black saxaul.

The area recommended for nomination could qualify as a serial transnational nomination (Kazakhstan, Turkmenistan and Uzbekistan), centred around the Repetek State Biosphere Reserve and overlapping with the Karakum and Kyzylkum Deserts. In case of serial nomination, it would go far beyond Repetek SBR as defined in the TL, and this should be reflected clearly in the final title of the nominated site.

The area will also include the Bereketli Garagum State Nature Reserve $\left(870 \mathrm{~km}^{2}\right)$, established in 2013, and could encompass the central part of the Kyzylkum Desert that is shared by Uzbekistan and Kazakhstan, to ensure good representation of this Central Asian ecosystem, as the largest Middle East Asian Desert. Thus, this will require the establishment of new protected area(s) in order to meet the WH Convention requirements.

124 https://whc.unesco.org/en/tentativelists/5435/.

125 TM 045 (http://datazone.birdlife.org/site/factsheet/repetek-iba-turkmenistan). 


\section{Justification of Outstanding Universal Value}

This site is a good example of "cold winter deserts" in Central Asia, an ecosystem currently unrepresented on the WH List and having high ecological and biological value, including original desert ecosystems exposed to natural factors (e.g., radiation, heat/cold, temperature, wind, water regime). It will meet criterion (ix) and may have potential for criterion ( $x$ ); however, its eligibility to meet the latter criterion should be assessed in more detail.

Criterion (ix): the site includes the main ecosystem components of "cold winter deserts" with their typical large black saxaul forests and sands, functional desert landforms, and natural processes (wind, erosion, endorheism, etc.), flora and fauna adaptation, and endemism associated with these ecosystems.

Criterion ( $x$ ): Repetek is one of the few natural desert sites in Central Asia with large areas of black saxaul; the area also supports the most complete assemblage of bird species typical of the Karakum sand desert and stable populations of globally threatened mammals and globally threatened and near threatened birds. It is also an important habitat for the Houbara bustard (Chlamydotis macqueenii). ${ }^{126}$

\section{Integrity}

Remote and pristine area; good integrity

\section{Comparison with other similar areas}

The site should be compared with similar sites in the Kyzylkum Desert (Uzbekistan) and Gobi Desert (Mongolia), and to other desert landforms worldwide (IUCN, 2011).

More specifically, comparisons should be made to the existing properties encompassing desert ecosystems (Lut, Iran; Western Desert, Egypt; Namib Desert, Namibia; Chott el Jerid, Tunisia; Thar Desert, India; Taklimakan, China; Wadi Rum, Jordan; El Pinacate, Mexico; and Ennedi, Chad, among others).

This nomination should be evaluated in relation to the recommended extension of Saryarka - Steppe and Lakes of Northern Kazakhstan WH property to Irgiiz Turgay Reserve, which also overlaps with Central Asia desert ecosystems (Section 5.1.2) and to the potential nomination of Altyn Emel (Section 5.2.3). It should also be appraised in relation to the two following recommendations that also encompass desert ecosystems.

\subsubsection{Southern Ustyurt Plateau}

In addition to the recommendations above of extending Saryarka - Steppe and Lakes of Northern Kazakhstan to Irgiiz Turgay Reserve, which also overlaps with Central Asia desert ecosystems (Section 5.1.2), and nominating Altyn-Emel (Section 5.2.3) and Repetek (Section 5.2.4), a further recommendation is to assess the potential of the Ustyurt Plateau for nomination.

\section{Description}

This low plateau is a very large desert area overlapping with Kazakhstan and Uzbekistan and bordering the Kyzylkum Desert that is also shared with Turkmenistan, between 
the Caspian and Aral seas. It encompasses an area of approximately $200,000 \mathrm{~km}^{2}$, at elevations from $100 \mathrm{~m}$ to $350 \mathrm{~m}$, and characterised by a now dried-up sea that existed there 21 million years ago.

This area is currently not included on any TL under natural criteria. ${ }^{127}$

The site will be transboundary or serial transnational (Kazakhstan, Turkmenistan and Uzbekistan) and it may include at least three components:

- Kaplankyr State Nature Reserve (Turkmenistan), established in 1979 and covering an area of 2,820 km;

- Ustyurt State Nature Reserve (Kazakhstan), established in 1984 and covering an area of $2,233 \mathrm{~km}^{2}$;

- a PA that is planned for establishment in Uzbekistan, at the border of the Ustyurt Plateau in the Kyzylkum Desert.

\section{Justification of Outstanding Universal Value}

This area is a good example of "cold winter deserts" in Central Asia, including original desert ecosystems of high ecological and biological value, subject to natural and climatic driving factors (radiation, heat/cold, temperature, wind, water regime, etc.) which are currently unrepresented on the WH List.

It may meet criterion (ix) and may have potential for criteria (vii), (viii) and (x); however, its eligibility to meet the latter three criteria should be assessed in more detail.

Criterion (vii): the site contains superlative natural phenomena or desert areas of exceptional natural beauty and aesthetic importance, typical of this region and different from other desert ecosystems worldwide;

Criterion (viii): it is an outstanding example representing major stages of the Earth's history in this part of the world, and significant on-going geological processes in the development of desert landforms, very specific to the region due to the geological and climatic original contexts and influences;

Criterion (ix): it illustrates the main ecosystem components of the "cold winter deserts" with their typical large black saxaul forests and sands, functional desert landforms, and serves as an excellent example of the natural processes characterising the evolution and development of those ecosystems (wind, erosion, endorheism, flora and fauna adaptation and endemism);

Criterion ( $x$ ): it hosts flora and fauna species and ecosystems, specific of cold desert ecosystems (high endemism) and overlaps with at least one IBA located in the Kazakh part of the plateau, ${ }^{128}$ providing a typical assemblage of desert species and other taxa, with a locally high density of breeding raptors.

\section{Integrity}

The existing PAs benefit from an adequate protection regime and are under moderate and local anthropogenic threats and impacts (ancient signs of extractive and quarrying activities; pipeline construction locally but outside the protected areas). The management

127 It was included on the TL of Kazakhstan as part of the "Silk Road" in 2012, under cultural criteria (https://whc. unesco.org/en/tentativelists/5754/).

$128 \mathrm{KZ} 018$ (http://datazone.birdlife.org/site/factsheet/north-western-cliff-faces-of-the-ustyurt-plateau-ibakazakhstan). (see also: Barge, 2015). 
plans/systems also seem appropriate (institutional, technical and financial capacities), though their effective implementation should be assessed further.

There needs, however, to be a trilateral agreement among the three States Parties to have a common vision and understanding of the protection and management of the area as a whole in the future, before any nomination.

\section{Comparison with other similar areas}

The site should be compared with similar sites in the Kyzylkum Desert (Uzbekistan) and the Gobi Desert (Mongolia), and to other desert landforms worldwide.

More specifically, comparisons should be made to the existing properties overlapping desert ecosystems (Lut, Iran; Western Desert, Egypt; Namib Desert, Namibia; Chott el Jerid, Tunisia; Thar Desert, India; Taklimakan, China; Wadi Rum, Jordan; El Pinacate, Mexico; and Ennedi, Chad, among others).

\subsubsection{Cold winter deserts of Central Asia}

This option combines several areas recommended above, including:

- Berektli Garagum SNR (Section 4.2.3);

- $\quad$ Altyn-Emel already listed on the TL of Kazakhstan (Section 5.2.2.3);

- Repetek State Biosphere Reserve, also covering a site already listed on the TL of Turkmenistan (Section 5.2.2.4);

- $\quad$ Southern Ustyurt Plateau (Section 5.2.2.5).

It will establish a "finite" serial transnational site, intending to represent those unique types of cold winter desert ecosystems.

Although potentially difficult to implement, this alternative should be assessed further, to verify its relevance and operational feasibility.

\section{Justification of Outstanding Universal Value}

The site recommended will be a good example of the "cold winter deserts" specific to the region. It would include original desert ecosystems of high ecological and biological value that are subject to very specific natural factors (radiation, heat/cold, temperature, wind, water regime, etc.), and that are currently unrepresented on the WH List.

The site will meet criterion (ix) and may have potential for criteria (vii), (viii) and (x); however, its eligibility to meet the latter three criteria should be assessed in more detail.

Criterion (vii): the site contains natural features characterising desert areas of exceptional natural beauty and aesthetic importance, typical of the region and different from other desert ecosystems worldwide;

Criterion (viii): it is an outstanding example of stages of the Earth's history in this part of the world and also illustrates significant on-going geological processes in the development of desert landforms, very specific to the region, due to geological and climatic original contexts;

Criterion (ix): it illustrates the main ecosystem components of the "cold winter deserts" with their typical large black saxaul forests and sands, functional desert landforms, and serves as an excellent example of biological processes characterising the evolution and 
development of those ecosystems (wind, erosion, endorheism, flora and fauna adaptation and endemism).

Criterion ( $x$ ): it hosts flora and fauna specific of cold desert ecosystems (high endemism) and overlaps with several IBAs and KBAs, providing a typical assemblage of desert species and other taxa, with a locally high density of breeding raptors.

\section{Integrity}

The existing PAs benefit from an adequate protection regime and are under moderate and local human pressures (ancient signs of extractive and quarrying activities; pipeline construction locally but outside the protected areas). Their management plans/systems seem also appropriate (institutional, technical and financial capacities), though their effective implementation should be assessed and discussed in more detail.

\section{Comparison with other similar areas}

The site should be compared with similar sites in the Gobi Desert (Mongolia), and other desert landforms worldwide.

More specifically, comparisons should be made to the existing properties encompassing desert ecosystems (Lut, Iran; Western Desert, Egypt; Namib desert, Namibia; Chott el Jerid, Tunisia; Thar desert, India; Taklimakan, China; Wadi Rum, Jordan; El Pinacate, Mexico; and Ennedi, Chad, among others). 


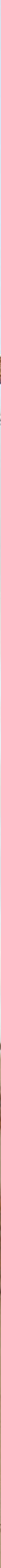




\section{Conclusions}

Since Magin (2005), significant progress has been made in better recognising the unique value of natural heritage in Central Asia. In recent years, several natural properties from the region have been inscribed on the WH List, while others have been included on national TLs, pending more in-depth analyses for potential nomination.

The work and consultations carried out during the present study has enabled stakeholders involved in the consultation process to better appreciate the current context and, based on improvement of the knowledge over the past fifteen years, to initiate a work programme including data collection and updating available information to facilitate identification of areas and sites with the highest potential for nomination, under the prioritised biodiversity criteria.

The recommendations that follow reflect this current level of knowledge and should be strengthened in the future to ensure that areas and sites identified and prioritised have the strongest assets for nomination. Therefore, these recommendations should be interpreted as a starting point for further technical analysis.

However, though this study is an initial assessment, most areas and sites recommended here below have appeared repeatedly during the work process and over time, as being of particular interest for biodiversity, whether through the analysis of literature, or in discussions between experts and specialists.

They have been prioritised, based on their value, level of integrity, exposure to potential threats, and an initial assessment of their legal protection regime and management, by cross-referencing the available information and data. Several of the recommended areas and sites are serial and/or transnational or transboundary.

Nine areas and sites have been recognised as having strong potential for nomination under biodiversity criteria (ix) and/or ( $x$ ), in some cases in combination with other WH natural criteria (vii) and (viii):

- $\quad$ three sites already inscribed in the WH List that should be extended: Golden Mountains of Altai, Sayarka - Steppe and Lakes of Northern Kazakhstan, and Western Tien-Shan;

- four sites currently included on TLs: Tigrovaya Balka, Badhyz and Kopetdag Mountains, Northern Tien-Shan and Repetek State Biosphere Reserve;

- two areas not currently included on TLs: Southern Ustyurt Plateau and Cold Winter Deserts of Central Asia.

In all cases, the nominated sites' territories, component parts and boundaries need to be ascertained with greater precision.

In order to ensure the best preparation of the nomination dossier for these sites, it is also highly recommended that the State Parties carefully follow the guidance of the UNESCO manual, published in partnership with the advisory bodies, on how to prepare WH nominations, ${ }^{129}$ and the UNEP-WCMC publication on comparative analysis methodology for WH nominations under biodiversity criteria, which should also be very 
helpful in the nomination process. ${ }^{130}$ The upstream process created by the WHC in 2010 may also contribute in providing essential support to State Parties for the preparation of nomination documents. ${ }^{131}$

Finally, it is worth noting that local communities inhabit some very remote areas prioritized above, at least seasonally and sometimes year-round. Unfortunately, it was beyond the scope of this survey to address the cultural aspect and indigenous matters, but it is fundamental to underline that rights issues have to be appropriately considered during every nomination process. The State Parties and all experts and organizations associated in such a process are strongly advised to address this central topic and refer to the existing "good practices" in relation to human rights and World Heritage when starting their work. ${ }^{132}$

\section{Additional recommendations}

It was also deemed useful to make a series of additional operational recommendations, intended to fill the major administrative and technical gaps and difficulties observed during the study.

The following recommendations seek to guide and facilitate the future work of States Parties, having in mind that the nomination of sites for their inscription on the WH List is a long and difficult process that often requires years of study and work. This may generate frustration, should the proposal not be properly prepared and thus endorsed.

\section{Recommendation 1 - Create and/or update current Tentative Lists}

State Parties are encouraged and invited to re-examine or review their Tentative Lists (TLs), with a focus on criteria (ix) and ( $\mathrm{x}$ ), without excluding other natural criteria (vii and/ or viii). Findings of this Thematic Study should be taken into account while reviewing TLs.

All TLs should be updated after a consultation process to ensure that the sites included in the lists are harmonized and have the highest potential for nomination at the regional level, based on a solid overall comparative analysis, which could not be performed during this process. States Parties are invited to take into account the findings and recommendations of this study into these processes.

A comparative analysis specific to each site should also provide useful information on its value, main attributes and features for potential nomination under either criterion. ${ }^{133}$ The purpose of this analysis is to ascertain whether there is scope for the inclusion of the site on the list, and to demonstrate that there is no other natural property with similar values inscribed on the TL, or that might be nominated in the future and have a higher value.

\footnotetext{
130 IUCN (2014a).

131 Decision WHC 40 COM 9 A (https://whc.unesco.org/en/decisions/?id decision=6842\&).

132 Larsen (2012a, b); IUCN (2014b).

133 IUCN (2014a).
} 


\section{Recommendation 2 - Improve the protection regime of areas and ecological corridors that have the highest values for natural heritage}

Central Asia is a global biodiversity hotspot, home to numerous iconic and threatened species and key natural habitats and ecosystems. They include significant migratory routes and flyways, and important breeding areas.

Source populations of several species are known to be located there as well; saiga is one such species, and likely the most iconic. In this context, the establishment of adequate BZs will be of the highest importance for nomination under either biodiversity criterion, to enhance and maintain the natural processes and preserve the state of conservation of those species.

Thus, the ecological corridors and key habitats for wildlife throughout the year should be first clearly identified, then delimitated and prioritised. In this context, identification of areas of sufficient size and establishment of adequate buffer zones will be of the highest importance for nomination under either biodiversity criterion, to enhance and maintain the natural processes and preserve the state of conservation of those species. This work will seek inputs of expertise from the IUCN SSC Specialist Groups and other relevant conservation expertise (e.g. conservation NGOs, scientific bodies of the relevant international conventions ${ }^{134}$ ).

The IUCN guidelines on areas of connectivity and transboundary conservation may also be helpful in designing sites and their BZs, and progressing towards the establishment of adequate legal regimes of protection and management frameworks (IUCN, 2016a).

The fact that areas or sites may be not currently under protection should never be used by the State Parties as an argument to exclude them from their TLs, if those areas and sites have high potential for nomination. Instead, this potential for nomination should be used by the State Parties to improve their current level of protection and management.

\section{Recommendation 3 - Consider a range of international designation mechanisms to recognize areas of global importance}

Areas of international importance and sites recognised under other international legal instruments or through knowledge-based tools (international/regional inventories of areas important for biodiversity conservation can help formulate Statements of Outstanding Universal Value (OUV) of existing and future WH sites.

State Parties should consider those already existing designations and inventories as opportunities to identify and select the areas and sites having the highest potential for nomination.

134 e.g.: Convention on Migratory Species, Ramsar Convention and their subsequent agreements and programmes. 


\section{Recommendation 4 - Foster transnational cooperation and transboundary sites, to support ecological functionality that guarantees the maintenance of natural processes}

There is strong potential for identifying transboundary and transnational sites. Some protected areas from the region may have difficulty in meeting the $\mathrm{WH}$ requirements if only areas within one country are included. Therefore, it would be helpful to foster cooperation and agree on a common regional strategic approach between State Parties for the identification and delimitation of transnational and/or transboundary sites.

States Parties are invited to build a common vision of $\mathrm{WH}$ in the region to facilitate the nomination of natural sites having the highest potential under natural criteria, especially in the cold winter desert ecosystems that are poorly represented on the WH List, based on the recommendations made in this study.

\section{Recommendation 5 - Develop continuous dialogue among stakeholders}

The need to develop dialogue among stakeholders at all levels - national, regional and international - emerged as one of the major conclusions of the consultations conducted during this study. This dialogue should be strengthened in the future, based on more frequent and regular exchanges and stronger cooperation among members of all groups of stakeholders (e.g. State Parties, scientists, NGOs, local communities) and between those groups.

International organisations should encourage this dialogue, facilitate exchange of good practices and contribute to identifying solutions to common problems, and the means to facilitate the nomination processes.

\section{Recommendation 6 - Improve enforcement and compatibility between local, national and international laws}

Difficulties in the practical implementation of international laws and agreements at the national and local levels, related to a lack of compatibility among the diverse regulations, were raised during the consultations.

Efforts should be made by the States Parties to improve this compatibility in the future and adapt their internal law and regulations to their international commitments. 


\section{Recommendation 7 - Conduct training sessions and activities on how to prepare site nomination}

Consultation workshops confirmed that difficulties observed during the IUCN evaluation process could be associated with the lack of capacity for WH nomination. In order to overcome these shortcomings, there is a need to develop operational guidance focusing on specific phases of the nomination process, such as preparing the comparative analysis, nomination under criteria (ix) and serial and/or transnational or transboundary sites.

Based on existing good practices and guidance documentation, specific training and tutoring activities should be organised during the upstream process of site nomination, for public service officers and local specialists, with support from IUCN and other relevant international organizations. 


\section{Bibliography}

Allan, J.R., Kormos, C.F., Jaeger, T., Venter, O., Bertzky, B., Shi, Y., Mackey, B.G., van Merm, R. Osipova, E. and Watson, J.E.M. (2018). 'Gaps and opportunities for the World Heritage Convention to contribute to global wilderness conservation'. Conservation Biology 32:116-126. Available from: https://doi.org/10.1111/cobi.12976.

Barge, O., Brochier, J., Deom, J., Sala, R. Karakhanyan, A., Avagyan, A. and Plakhov, K. (2019). 'The 'desert kites' of the Ustyurt plateau'. Quaternary International 395: 113132. Available from: https://doi.ora/10.1016/i. quaint.2015.06.010.

Bertzky, B., Shi, Y., Hughes, A., Enge/s, B., Ali, M.K. and Badman, T. (2013). Terrestrial biodiversity and the World Heritage List: Identifying broad gaps and potential candidate sites in the natural World Heritage network. Gland, Switzerland and Cambridge, UK: IUCN and UNEP-WCMC. Available from: https:// portals.iucn.org/library/node/10399.

BirdLife International (2019). Digital Boundaries of Important Bird and Biodiversity Areas from the World Database of Key Biodiversity Areas. March 2019 Version. Available from: http:// datazone.birdlife.org/site/requestgis.

Bragin E. (2010). Review of the situation in the Balkhash lake basin and water management policy of the lly-Balkhash basin.

The Clearing-House Mechanism of the Convention on Biological Diversity (2019). Available from: https://chm.cbd.int/search/ reporting-map? filter $=\mathrm{nr} 6$ [Accessed 30 Sep. 2019].

Critical Ecosystems Partnership Fund (2017) Ecosystem Profile - Mountains of Central Asia, Biodiversity Hotspot. CEPF. Available from: https://www.cepf.net/our-work/biodiversityhotspots/mountains-central-asia [Accessed 30 Sep. 2019].

Chestin, I., Paltsyn, M., Pereladova, O., legorova, L. and Gibbs, J. (2017). 'Tiger re-establishment potential to former Caspian tiger (Panthera tigris virgata) range in Central Asia'. Biological Conservation, 205:42-51. Available from: https:// doi.org/10.1016/j.biocon.2016.11.014.

Commission on National Parks and Protected Areas (CNPPA) (1982). The World's Greatest Natural Areas: an indicative inventory of natural sites of World Heritage quality. Gland, Switzerland: IUCN. Available from: https:// portals.iucn.org/library/node/5828.

Datazone.birdlife.org (2019). BirdLife Data Zone. [online] Available from: http://datazone. birdlife.org/site/mapsearch [Accessed 19 Sep. 2019].
Dinerstein, E. (2017). 'An Ecoregion-based Approach to Protecting Half the Terrestrial Realm'. BioScience, 67(6): 534-545. Available from: https://doi.org/10.1093/biosci/bix014.

Dostaj, J.D. (2006). Wasserressourcen und deren Nutzung im Ili-Balchas Becken. Giessen, Germany: ZEU.

Driscoll, C., Luo, S., MacDonald, D., Dinerstein E., Chestin, I., Pereladova, O. and O'Brien, S. (2011). 'Restoring tigers to the Caspian region'. Science 333(6044): 822-823. Available from: https://doi.org/10.1126/science.333.6044.822-b.

Driscoll, C., Chestin, I., Jungius, H., Pereladova, O., Darman, Y., Dinerstein, E., Seidensticker, J., Sanderson, J., Christie, S., Luo, S., Shrestha, M. Zhuravlev, Y., Uphyrkina, O., Jhala, Y., Yadav, S., Pikunov, D., Yamaguchi, N., Wildt, D., Smith, J., Marker, L., Nyhus, P., Tilson, R., Macdonald, D. and O'Brien, S. (2012). 'A postulate for tiger recovery: the case of the Caspian Tiger' Journal of Threatened Taxa 4(6): 2637-2643. Available from: https://doi.org/10.11609/JoTT.02993.263743.

Eastwood, A., Lazkov, G. and Newton, A.C. (2009). The Red List of Trees of Central Asia. Richmond, GB: Botanic Gardens Conservation International. Available from: https://portals. iucn.org/library/sites/library/files/documents/ RL-2009-006.pdf.

Garstecki, T.H., Abdulhalim, M.K. and van Merm, R. (2011). Nature and World Heritage in the Arab States: towards future IUCN priorities. Gland, Switzerland: IUCN. Available from: https://www.iucn.org/content/tabea-natureand-world-heritage-arab-states-towardsfuture-iucn-priorities.

Geiger, R. (1961). Überarbeitete Neuausgabe von Geiger, R.: Köppen-Geiger Klima der Erde. (in German) [map, 1:16mil]. Gotha, Germany: Klett-Perthes.

Global Environment Facility (GEF) (2002). Development of the Econet for long-term conservation of biodiversity in Central Asia Ecoregions. GEF.

Haddad, N., Brudvig, L., Clobert, J., Davies, K Gonzalez, A., Holt, R., Lovejoy, T., Sexton, J., Austin, M., Collins, C., Cook, W., Damschen, E., Ewers, R., Foster, B., Jenkins, C., King, A. Laurance, W., Levey, D., Hoffman, M., Koenig, K., Bunting. G., Costanza, J. and Williams, K. (2019). Biodiversity Hotspots (version 2016.1). Zenodo. Available from: http://doi.org/10.5281/ zenodo.3261807 [Accessed 19 Sep. 2019].

Ibisch, P.L., Hoffmann, M.T., Kreft, S., Pe'er, G., Vassiliki, K., Biber-Freudenberger, L., DellaSala, D.A. Vale, M.M., Hobson, P.R., and Selva, N. (2016) 'A global map of roadless areas and their conservation status'. Science 354:6318, 14231427. Available from: https://doi.org/10.1126/ science.aaf7166 
Imentai, A., Thevs, N., Schmidt, S., Nurtazin, S. and Salmurzauli, R. (2015). 'Vegetation, fauna, and biodiversity of the lle Delta and southern Lake Balkhash - A review.' Journal of Great Lakes Research, 41(3):688-696. Available from: https://doi.org/10.1016/j.jglr.2015.04.002.

Intergovernmental Science-Policy Platform on Biodiversity and Ecosystem Services (IPBES) (2018). Summary for policymakers of the regional assessment report on biodiversity and ecosystem services for Europe and Central Asia of the Intergovernmental Science-Policy Platform on Biodiversity and Ecosystem Services. Bonn, Germany: IPBES. Available from: https://ipbes.net/assessment-reports/ eca.

International Union for Conservation of nature (IUCN) (1998). World Heritage Nomination IUCN Technical Evaluation, Golden Mountains of Altai (Russian Federation). Gland, Switzerland: IUCN. Available from: https://whc. unesco.org/en/list/768/documents/.

IUCN (2003). IUCN Evaluation of Nominations of Natural and Mixed Properties to the World Heritage List: report to the World Heritage Committee, Twenty-seventh session. Gland, Switzerland: IUCN. Available from: https://whc. unesco.org/en/sessions/27COM/documents/.

IUCN (2004). The World Heritage List: Future priorities for a credible and complete list of natural and mixed sites. Gland, Switzerland: IUCN. Available from: https://www.iucn.org/ sites/dev/files/import/downloads/ouv2004 english.pdf.

IUCN (2008). World Heritage Nomination - IUCN Technical Evaluation, Saryarka Steppe and Lakes of Northern Kazakhstan (Kazakhstan). Gland, Switzerland: IUCN. Available from: https://whc.unesco.org/ archive/2008/whc08-32com-inf8B2e.pdf.

Goudry, A. and Seely, M. (2011). World Heritage Desert Landscapes: Potential Priorities for the Recognition of Desert Landscapes and Geomorphological Sites on the World Heritage List. Gland, Switzerland: IUCN. Available from: https://portals.iucn.org/library/node/9818.

ICCROM, ICOMOS and IUCN (2014). World Heritage and Rights-Based Approaches. Building capacity to support rights-based approaches in the World Heritage Convention: learning from practice. Report from workshop in Oslo, 1-3 April 2014. Oslo, Norway: ICOMOS. Available from: https://portals.iucn.org/library/ node/44765.

Belle E., Shi Y., and Bertzky B. (2014)

Comparative Analysis Methodology for World Heritage nominations under biodiversity criteria: A contribution to the IUCN evaluation of natural World Heritage nominations. UNEPWCMC, Cambridge, UK and IUCN, Gland Switzerland. Available from: https://www.unepwcmc.org/resources-and-data/comparativeanalysis-methodology-for-world-heritagenominations-under-biodiversity-criteria.

IUCN (2014). Comparative analysis methodology for World Heritage nominations under biodiversity criteria: A contribution to the IUCN evaluation of natural World Heritage nominations. Cambridge, UK, and Gland, Switzerland: UNEP-WCMC and IUCN.
IUCN (2016a). Guidelines for areas of connectivity conservation: definition, types, selection criteria and governance. Gland, Switzerland and Cambridge, UK: IUCN.

IUCN (2016b). World Heritage Nomination - IUCN Technical Evaluation. Western TienShan (Kazakhstan, Kyrgyzstan, Uzbekistan). Gland, Switzerland and Cambridge, UK: IUCN. Available from: https://whc.unesco.org/ archive/2016/whc16-40com-inf8B2-en.pdf

Jungius, H. (2010). Feasibility Study on the Possible Restoration of the Caspian Tiger in Central Asia. Moscow, Russia: WWF Russia. Available from: https://wwf.ru/en/resources/ publications/booklets/feasibility-study-onthe-possible-restoration-of-the-caspian-tigerin-central-asia/.

Karimov, K., Kachel, S. and Hackländer, K. (2018). 'Responses of snow leopards, wolves and wild ungulates to livestock grazing in the Zorkul Strictly Protected Area, Tajikistan'. PLOS ONE, 13(11). Available from: https://doi.org/10.1371/journal.pone.0208329

Karpovicz, Z and Reap, J. (2002). Mission to Almaty, Kazakhstan, mission report, 16-22 December 2002. Gland, Switzerland: IUCN.

Kashkarov, R.D., Welch, G.R. and Brombacher, M. (eds) (2008). Important Bird Areas in Uzbekistan - priority sites of conservation. Tashkent: Uzbekistan Society for the Protection of Birds.

Keybiodiversityareas.org. (2019). World Database of Key Biodiversity Areas. Available from: http://www.keybiodiversityareas.org/ [Accessed 19 Sep. 2019].

Kormos, C., Bertzky, B., Jaeger, T., Shi, Y., Badman, T., Hilty, J., Mackey, B., Mittermeier, R., Locke, H., Osipova, E. and Watson, J. (2015). 'A Wilderness Approach under the World Heritage Convention'. Conservation Letters, 9(3), pp.228-235. Available from: https://doi. org/10.1111/conl.12205.

Kormos, C.F., Badman, T., Jaeger, T., Bertzky, B., van Merm, R., Osipova, E., Shi, Y. and Larsen, P.B. (2017) World Heritage, Wilderness, and Large Landscapes and Seascapes. Gland, Switzerland: IUCN. Available from: https://doi. org/10.2305/IUCN.CH.2017.06.en.

Krever, V., Pereladova, O., Williams, M., and Jungius, H. (1998). Biodiversity Conservation in Central Asia: an analysis of biodiversity and current threats and initial investment portfolio Gland, Switzerland: WWF International. Available from: https://portals.iucn.org/library/ node/23797.

Kvartalnov, P. (2011). Tugay Forests in Tajikistan: the last remainders of globally endangered ecosystem: detailed final report for Rufford Small Grants Project 93047. London, UK: The Rufford Foundation. Available from: https://www.rufford.org/ files/9304-1\%20Detailed\%20Final\%20Report. pdf. 
Larsen, P.B. (2012a). IUCN, World Heritage and Evaluation Processes Related to Communities and Rights: An independent review. Gland, Switzerland: IUCN. Available from: https:// www.academia.edu/4541307/IUCN_World Heritage and Evaluation Processes Related to Communities and Rights 2012.

Larsen, P.B. (2012b). Advisory Body Evaluations of World Heritage nominations in Relation to Community and Rights Concerns, Independent Assessment. A discussion paper. Italy, Norway and Switzerland: ICCROM, ICOMOS and ICCROM. Available from: https://www.iucn.org/sites/dev/files/ import/downloads/world heritage and communities advisory body follow up larsen_2012.pdf.

Le Saout, S., Hoffmann, M., Shi, Y., Hughes, A. Bernard, C., Brooks, T.M., Bertzky, B., Butchart, S.H.M., Stuart, S.N., Badman, T., and Rodrigues, A.S.L. (2013). 'Protected areas and effective biodiversity conservation'. Science 342: 803805. Available from: https://doi.org/10.1126/ science.1239268.

Lysenko, I. (2007). Terminal Evaluation of the UNEP/GEF Project "Development of the Econet for Long-term Conservation of Biodiversity in Central Asia Ecoregions". Washington D.C., USA: GEF. Available from: https://www.thegef.org/project/developmenteconet-long-term-conservation-biodiversitycentral-asia-ecoregions

Magin, C. (2005). World Heritage Thematic Study for Central Asia: A Regional Overview. Gland, Switzerland: IUCN. Available from: https://portals.iucn.org/library/node/12796.

Margules, C., Melbourne, B., Nicholls, A., Orrock, J., Song, D. and Townshend, J. (2015). 'Habitat fragmentation and its lasting impact on Earth's ecosystems'. Science Advances, 1(2), p.e1500052. Available from: https://doi. org/10.1126/sciadv.1500052.

Moehlman, P. D. (ed.) (2002). Equids: Zebra, Asses, and Horses. Status Survey and Conservation Action Plan. Gland, Switzerland and Cambridge, UK: IUCN/SSC Equid Specialist Group. Available at: https://portals. iucn.org/library/node/8130.

Myers, N. (1988). 'Threatened biotas: "Hot spots" in tropical forests'. The Environmentalist, 8(3):187-208. Available from: https://doi.org/10.1007/BF02240252.

Myers, N., Mittermeier, R., Mittermeier, C., da Fonseca, G. and Kent, J. (2000). 'Biodiversity hotspots for conservation priorities'. Nature, 403(6772):853-858. Available from: https:// doi.org/10.1038/35002501.

Olson, D., Dinerstein, E., Wikramanayake, E., Burgess, N., Powell, G., Underwood, E., D'amico, J., Itoua, I., Strand, H., Morrison, J., Loucks, C., Allnutt, T., Ricketts, T., Kura, Y., Lamoreux, J., Wettengel, W., Hedao, P. and Kassem, K. (2001). 'Terrestrial Ecoregions of the World: a new map of life on Earth'. BioScience, 51(11):933. Available from: https://doi.org/10.1641/00063568(2001)051[0933:TEOTWA]2.0.CO;2.
Olson, D. M. and Dinerstein, E. (2002). 'The Global 200: Priority ecoregions for global conservation'. Annals of the Missouri Botanical Garden 89(2): 199-224. Available from: https:// doi.org/10.2307/3298564.

Plakhov, K.N., Sokolov, S.V., Levanov, V.F., and Akylbekova, A.Z. (2012). 'News in Kulan reintroduction in Kazakhstan'. In: Meldebekov, A.M., Bekenov, A.B., Grachev, Y.A., Baydavletov, R.Z., Sklyarenko, S.L., and Bodrova, N.P. (Eds.); Zoological and game management researches in Kazakhstan and adjacent countries. Materials on international theoretical and practical conference devoted to centenary of birth of the founder of Kazakhstan's theriology and game management schools, a Laureate of State Prizes of USSR and KazSSR, a Corresponding Member of AS of KazSSR. Arkadiy Alexandrovich Sludskiy (Almaty, 1-2 March 2012), pp. 151-153. Almaty, Kazakhstan (In Russian).

Potapov, P., Hansen, M., Laestadius, L., Turubanova, S., Yaroshenko, A., Thies, C. Smith, W., Zhuravleva, I., Komarova, A., Minnemeyer, S. and Esipova, E. (2017). 'The last frontiers of wilderness: Tracking loss of intact forest landscapes from 2000 to 2013'. Science Advances, 3(1), p.e1600821. Available from: https://doi.org/10.1126/ sciadv.1600821.

Rachkovskaya, E.I. (1995). Kazakhstan semideserts and melkosopochnik. Vegetation Map of Kasakhstan and Middle Asia (1:2,500,000). Saint Petersburg, Russia: Komarov Botanic Institute of the Russian Academy of Sciences.

Rachkovskaya, E.I., Volkova, E.A., Khramtsov, V.N., (2003). Botanical Geography of Kazakhstan and Middle Asia (Desert Region). St Petersburg (in Russian).

Rustamov E.A., Welch G.R., and Brombacher, M. (eds.) (2009): Important Bird Areas in Turkmenistan -priority sites for conservation. Ashgabat, Turkmenistan: Ministry of Nature Protection.

Rustamov, A.E. (ed.) (2018). Update information on the status of the wetlands in Kazakhstan, Kyrgyzstan and Turkmenistan by collection and dissemination of good practices for conservation and sustainable use of wetlands by local communities. Almaty. Available from: https://carececo.org/en/ main/ckh/publications/obnovlenie-svedeniyo-statuse-vodno-bolotnykh-ugodiy-vkazakhstane-kyrgyzstane-i-turkmenistane/.

Sanderson, E.W. (2002). 'The Human Footprint and The Last of the Wild'. BioScience 52(10): 891-904. Available from: https://doi. org/10.1641/0006-3568(2002)052[0891:THFA TL]2.0.CO;2.

Schmidt, S. (2017). Spatial Analysis of Conservation Potential in Cold Winter Deserts of Central Asia. FINC-report 201701. FINC-Foundation, Greifswald. Available from: https://cadi.uni-greifswald.de/wpcontent/uploads/2017/06/spatial-analysis conservation-potential cold-winter-desertsCA.pdf. 
Schroeder, F.G. (1998). Lehrbuch der Pflanzengeographie UTB für Wi., Wiesbaden: Quelle and Meyer.

Schultz, J. (2005). The Ecozones of the World: The Ecological Division of the Geosphere. Berlin, Germany and Heidelberg. Germany: Springer-Verlag. Available from: https://doi. org/10.1007/3-540-28527-X.

Sdykova, A. (2006). Compatibility of Selected Natural Protected Areas of Kazakhstan with the Requirements of the World Heritage Convention for the Nominated sites. Budapest, Hungary: Central European University.

Shmida (1985). 'Biogeography of the desert floras of the world'. In: Hot Deserts. Evenari, M., Meir, I.N., and Goodall, D.W. (eds.) Ecosystems of the World, Vol. 12A, 23-77. Amsterdam, The Netherlands: Elsevier

Sklyarenko, SL., Welch, R., and Brombacher, M. (2008). Important Bird Areas in Kazakhstan - priority sites for conservation. Almaty, Kazakhstan: Association for the Conservation of Biodiversity of Kazakhstan.

Ten, A., Kashkarov, R., Matekova, G., Zholdasova, I., and Turaev, M. (2012). 'Akpetky lakes, Sarykamysh lake, Ayakaghytma lake, and their desert surrounds: three new Important Bird Areas in Uzbekistan'. Sandgrouse 34(2):137 -147. Available from: http://www.uzspb.uz/sandgrouse2012.pdf.

Thorsell, J. and Hamilton, L. (2002). A Global Overview of Mountain Protected Areas on the World Heritage List: A Contribution to the Global Theme Study of World Heritage Natural Sites. Working Paper 6. Gland, Switzerland: IUCN. Available from https://portals.iucn.org/ library/node/8108.

Udvardy, M. (1975). A classification of the biogeographical provinces of the world. Prepared as a contribution to UNESCO's Man and Biosphere Programme, Project 8. IUCN Occasional paper 18. Morges, Switzerland: IUCN. Available from: https://www.iucn.org/ es/node/23206.

United Nations Educational, Scientific and Cultural Organization (UNESCO) (1972). Convention concerning the protection of the World Cultural and Natural Heritage, adopted by the General Conference at its $17^{\text {th }}$ Session. Paris, France: UNESCO

UNESCO (2002). Proceedings of UNESCO Regional Workshop: Possibilities of Nominations on World Natural and Mixed Heritage in Central Asia. National Academy of Sciences, Almaty, Kazakhstan. 16-18 December 2002. Paris, France: UNESCO.

UNESCO (2002/2004). TLs Brief Descriptions submitted by the Central Asian States Parties. Paris, France: UNESCO.

UNESCO (2011). Preparing World Heritage Nominations, second edition. Paris, France: UNESCO. Available from: https://whc. unesco.org/en/preparing-world-heritagenominations/.
UNESCO (2017). Operational Guidelines for the implementation of the World Heritage Convention. Paris, France: UNESCO. Available from: https://whc.unesco.org/en/guidelines/.

Walter, H. (1968). Die Vegetation der Erde in öko-physiologischer Betrachtung. Germany: Fischer Verlag. Available from: https://doi. org/10.1002/fedr.19760870307.

Wildlife Conservation Society (WCS) and Center for International Earth Science Information Network (CIESIN) Columbia University (2005). Last of the Wild Project, Version 2, 2005 (LWP-2): Global Human Footprint Dataset (Geographic). Palisades, NY: NASA Socioeconomic Data and Applications Center (SEDAC). Available from: https://doi. org/10.7927/H4M61H5F. (Accessed 2018).

World Wildlife Fund Russia (WWF Russia) (2005). Unique nature complexes of Central Asia; proposals for the list of UNESCO World Heritage natural sites. Moscow, Russia: WWF Russia.

WWF Russia (2006). ECONET. "Web for Life". Central Asia. Moscow, Russia: WWF Russia. Available from: https://wwf.ru/en/resources/ publications/booklets/econet-8220-web-forlife-8221-central-asia/.

Zoï Environment Network (2011) Biodiversity in Central Asia: A Visual Synthesis. Geneva, Switzerland. Available from: https://www. kz.undp.org/content/kazakhstan/en/home/ library/environment energy/biodiversity-incentral-asia--a-visual-synthesis.html.t 


\section{Annexes}

\section{Annex 1}

\section{Participants to the workshops and consulted experts}

\begin{tabular}{|c|c|}
\hline Name & Organisation \\
\hline \multicolumn{2}{|l|}{ Kazakhstan } \\
\hline Beisembayeva, Lazzat & Ministry of Culture and Sports \\
\hline Ilina, Viktoriya & Tethys Scientific Society \\
\hline Jashenko, Roman & Tethys Scientific Society \\
\hline Maltseva, Elina & National World Heritage Committee \\
\hline Massanov, Madjer & $\begin{array}{l}\text { Member of the World Heritage Committee of } \\
\text { Kazakhstan's National Commission, International Institute } \\
\text { for Central-Asian Studies (IICAS) }\end{array}$ \\
\hline Sklyarenko, Sergey & $\begin{array}{l}\text { Association for the Conservation of Biodiversity of } \\
\text { Kazakhstan }\end{array}$ \\
\hline \multicolumn{2}{|l|}{ Kyrgyzstan } \\
\hline Akulov, Ruslan & $\begin{array}{l}\text { Protected Areas department of State Agency for } \\
\text { Environmental Protection and Forestry }\end{array}$ \\
\hline Domashov, Ilia & National Expert \\
\hline Mambetaliev, Kumar & State Agency for Environmental Protection and Forestry \\
\hline Kirilenko, Ana & Ecological Movement "BIOM" \\
\hline Kirstad, Malen & BIOM international \\
\hline Rustamov, Abdykalyk & State Agency for Environmental Protection and Forestry \\
\hline Shukurov Japarovich, Emil* & Ecological Movement "BIOM" \\
\hline Soronkulov, Gamal & O০ Zamaat Alan-Too project \\
\hline Tentieva, Ainura & $\begin{array}{l}\text { Advisor for the National Commission of the Kyrgyz } \\
\text { Republic for UNESCO }\end{array}$ \\
\hline Turdumatov, Talantbek & State Agency for Environmental Protection and Forestry \\
\hline \multicolumn{2}{|l|}{ Tajikistan } \\
\hline Davlatzoda, Zevar & Ministry of Culture of Tajikistan \\
\hline Karimov, Khalil & Hunting and Conservation Alliance of Tajikistan \\
\hline Nazhmudinov, Najmiddin & $\begin{array}{l}\text { Sector for International Relations, tourism and tourist } \\
\text { marketing, State Institution of Specially Protected Natural } \\
\text { Areas }\end{array}$ \\
\hline Nuritdin Nazurleovich, Sayfulloev & $\begin{array}{l}\text { Department of Archaeology of the Institute of History, } \\
\text { Archaeology and Ethnography }\end{array}$ \\
\hline
\end{tabular}

* deceased 


\begin{tabular}{|c|c|}
\hline \multicolumn{2}{|l|}{ Turkmenistan } \\
\hline Allekow, Serdar & Society of Nature Protection of Turkmenistan \\
\hline Karryeva, Shirin & RSPB \\
\hline Rustamov, Eldar & Society for Nature Protection of Turkmenistan \\
\hline Saparmyradov, Jumamyrat & $\begin{array}{l}\text { National Institute of Desserts, Flora and Fauna, under the } \\
\text { State Committee on Environment Protection and Land } \\
\text { Resources of Turkmenistan }\end{array}$ \\
\hline \multicolumn{2}{|l|}{ Uzbekistan } \\
\hline Ahmedashaev, Ahmadjon & Geological Museum of the Republic of Uzbekistan \\
\hline Bykova, Elena & Uzbekistan Academy of Sciences · Institute of Zoology \\
\hline Khurramov, Farrukh & $\begin{array}{l}\text { Cadastre and Monitoring Department, Biological } \\
\text { Inspection under the State Committee of Ecology and } \\
\text { Environmental Protection }\end{array}$ \\
\hline Kasimova, Shahzoda & Geological Museum of the Republic of Uzbekistan \\
\hline Kashkarov, Roman & Institute of Zoology of the Republic of Uzbekistan \\
\hline Shagiahmetova, Gulshad & $\begin{array}{l}\text { Protected Areas Department, Biological Inspection under } \\
\text { the State Committee of Ecology and Environmental } \\
\text { Protection }\end{array}$ \\
\hline Sherimbetov, Khalilulla & $\begin{array}{l}\text { Protected Areas Department, Biological Inspection under } \\
\text { the State Committee of Ecology and Environmental } \\
\text { Protection }\end{array}$ \\
\hline Zagrebin, Sergey & Field Coordinator on Protected Areas \\
\hline Xamidov, Odiljon & Archaeology Samarkand \\
\hline \multicolumn{2}{|l|}{ IUCN } \\
\hline Erg, Boris & IUCN ECARO \\
\hline Hofman, Maarten & IUCN ECARO \\
\hline Nikodinovic, Aleksandra & IUCN ECARO \\
\hline Osipova, Elena & IUCN WHP \\
\hline Protas, Yelizaveta & IUCN ECARO \\
\hline Volonsyachuk, Roman & IUCN ECARO \\
\hline \multicolumn{2}{|l|}{ International experts } \\
\hline Akoijam, Yaziphaba & $\begin{array}{l}\text { Assistant Advisor for the Asia/Oceania Region, } \\
\text { Secretariat of the Ramsar Convention on Wetlands }\end{array}$ \\
\hline Ash, Neville & UNEP-WCMC \\
\hline Balbakova, Farida & $\begin{array}{l}\text { National coordinator of WWF projects in the Kyrgyz } \\
\text { Republic and Head of the NGO "GLIP" }\end{array}$ \\
\hline Bertzky, Bastian & Joint Research Centre (JRC) \\
\hline Bunting, Gill & BirdLife \\
\hline Dieterich, Til & NABU/International Eurasian Working Group \\
\hline Farhadinia, Mohammad & WildCRU, Zoology, University of Oxford \\
\hline Garstecki, Tobias & International World Heritage expert \\
\hline Jaeger, Tilman & International World Heritage expert \\
\hline Kaliankin, Michael & $\begin{array}{l}\text { Zoological Museum of Lomonosov, Moscow State } \\
\text { University }\end{array}$ \\
\hline
\end{tabular}




\begin{tabular}{|l|l|}
\hline Kang, Aili & WCS Executive Director, Asia Program \\
\hline Karina, Zhanel & Ramsar Regional Initiative for Central Asia (RRI-CA) \\
\hline Kormos, Cyril & $\begin{array}{l}\text { Executive Director, Wild Heritage and IUCN WCPA Vice } \\
\text { Chair, World Heritage }\end{array}$ \\
\hline Linnell, John & $\begin{array}{l}\text { Norwegian Institute for Nature Research (NINA), } \\
\text { Department of Terrestrial Ecology }\end{array}$ \\
\hline Launay, Frederic & Panthera \\
\hline Michel, Stefan & NABU \\
\hline Novikov, Viktor & Zoï Environment Network \\
\hline Ostrowski, Stephane & WCS \\
\hline Pereladova, Olga & WWF Central Asia Program \\
\hline Reiko, Litsuka & $\begin{array}{l}\text { Senior Regional Advisor for the Asia/Oceania Region, } \\
\text { Secretariat of the Ramsar Convention on Wetlands }\end{array}$ \\
\hline Roettger, Christiane & CMS \\
\hline Rothberg, Daniel & CEPF \\
\hline Wunderlich, Jens & Michael Succow Foundation \\
\hline Zuther, Steffen & $\begin{array}{l}\text { International coordinator of the Altyn Dala Conservation } \\
\text { Initiative, Frankfurt Zoological Society }\end{array}$ \\
\hline
\end{tabular}




\section{Annex 2}

\section{Terrestrial threatened species (fauna) $)^{135}$}

(Source: IUCN Red List of Threatened Species website, accessed 15 April 2018)

\begin{tabular}{|c|c|c|c|c|}
\hline Class & Genus & Species & Common names (Eng) & $\begin{array}{l}\text { Red List } \\
\text { status }\end{array}$ \\
\hline Amphibians & Ranodon & sibiricus & Semirechensk Salamander & EN \\
\hline \multirow[t]{27}{*}{ Birds } & Emberiza & aureola & Yellow-breasted Bunting & CR \\
\hline & Leucogeranus & leucogeranus & $\begin{array}{l}\text { Siberian Crane, Siberian White Crane, Snow } \\
\text { Crane }\end{array}$ & CR \\
\hline & Numenius & tenuirostris & Slender-billed Curlew & CR \\
\hline & Vanellus & gregarius & Sociable Lapwing, Sociable Plover & CR \\
\hline & Aquila & nipalensis & Steppe Eagle & EN \\
\hline & Falco & cherrug & Saker Falcon, Saker & EN \\
\hline & Haliaeetus & leucoryphus & $\begin{array}{l}\text { Pallas' Fish-eagle, Band-tailed Fish-eagle, } \\
\text { Pallas's Sea-Eagle }\end{array}$ & EN \\
\hline & Neophron & percnopterus & Egyptian Vulture, Egyptian Eagle & EN \\
\hline & Oxyura & leucocephala & White-headed Duck & EN \\
\hline & Anser & cygnoid & Swan Goose & VU \\
\hline & Anser & erythropus & Lesser White-fronted Goose & $\vee \cup$ \\
\hline & Aquila & heliaca & $\begin{array}{l}\text { Eastern Imperial Eagle, Asian Imperial Eagle, } \\
\text { Imperial Eagle }\end{array}$ & VU \\
\hline & Aythya & ferina & Common Pochard, Northern Pochard, Pochard & VU \\
\hline & Branta & ruficollis & Red-breasted Goose & VU \\
\hline & Bubo & scandiacus & Snowy Owl & VU \\
\hline & Chlamydotis & macqueenii & $\begin{array}{l}\text { Asian Houbara, Asian Houbara Bustard, } \\
\text { Macqueen's Bustard }\end{array}$ & VU \\
\hline & Clanga & clanga & Greater Spotted Eagle, Spotted Eagle & VU \\
\hline & Clangula & hyemalis & Long-tailed Duck & VU \\
\hline & Columba & eversmanni & $\begin{array}{l}\text { Yellow-eyed Pigeon, Yellow-eyed Dove, Yellow- } \\
\text { eyed Stock Dove }\end{array}$ & VU \\
\hline & Emberiza & rustica & Rustic Bunting & VU \\
\hline & Larus & relictus & Relict Gull & VU \\
\hline & Marmaronetta & angustirostris & Marbled Teal, Marbled Duck & VU \\
\hline & Melanitta & fusca & Velvet Scoter & VU \\
\hline & Otis & tarda & Great Bustard & VU \\
\hline & Podiceps & auritus & Horned Grebe, Slavonian Grebe & VU \\
\hline & Saxicola & insignis & $\begin{array}{l}\text { White-throated Bushchat, Hodgson's Bushchat, } \\
\text { White-throated Bush Chat }\end{array}$ & VU \\
\hline & Streptopelia & turtur & $\begin{array}{l}\text { European Turtle-dove, European Turtle Dove, } \\
\text { Turtle Dove }\end{array}$ & VU \\
\hline
\end{tabular}




\begin{tabular}{|c|c|c|c|c|}
\hline Class & Genus & Species & Common names (Eng) & $\begin{array}{l}\text { Red List } \\
\text { status }\end{array}$ \\
\hline \multirow[t]{11}{*}{ Insects } & Chalepoxenus & spinosus & & VU \\
\hline & Chalepoxenus & tarbinskii & & VU \\
\hline & Chalepoxenus & zabelini & & $\vee \cup$ \\
\hline & Graphoderus & bilineatus & & VU \\
\hline & Onychogomphus & assimilis & Dark Pincertail & VU \\
\hline & Onychogomphus & flexuosus & Waved Pincertail & $\vee \cup$ \\
\hline & Parnassius & apollo & Apollo, Apollo Butterfly, Mountain Apollo & VU \\
\hline & Parnassius & autocrator & & $\vee \cup$ \\
\hline & Phyllodesma & ilicifolia & Small Lappet Moth & VU \\
\hline & Saga & pedo & $\begin{array}{l}\text { Common Predatory Bush-cricket, Predatory } \\
\text { Bush Cricket }\end{array}$ & $\vee \cup$ \\
\hline & Strongylognathus & minutus & & $\vee \cup$ \\
\hline \multirow[t]{17}{*}{ Mammals } & Camelus & ferus & $\begin{array}{l}\text { Bactrian Camel, Two-humped Camel, Wild } \\
\text { Bactrian Camel }\end{array}$ & $\begin{array}{c}\text { CR } \\
\text { (extinct } \\
\text { in Central } \\
\text { Asia) }\end{array}$ \\
\hline & Mustela & lutreola & European Mink & $\begin{array}{c}\mathrm{CR} \\
\text { (extinct in } \\
\mathrm{CA} \text { ) }\end{array}$ \\
\hline & Saiga & tatarica & Saiga, Mongolian Saiga, Saiga Antelope & $\mathrm{CR}$ \\
\hline & Cuon & alpinus & $\begin{array}{l}\text { Dhole, Asiatic Wild Dog, Indian Wild Dog, Red } \\
\text { Dog }\end{array}$ & $\begin{array}{l}\text { EN (to be } \\
\text { assessed) }\end{array}$ \\
\hline & Desmana & moschata & Russian Desman & EN \\
\hline & Equus & ferus & $\begin{array}{l}\text { Przewalski's Horse, Asian Wild Horse, Mongolian } \\
\text { Wild Horse }\end{array}$ & EN \\
\hline & Panthera & tigris & Tiger & $\begin{array}{c}\text { EN } \\
\text { (extinct in } \\
\text { CA) }\end{array}$ \\
\hline & Acinonyx & jubatus & Cheetah, Hunting Leopard & $\begin{array}{l}V U \\
\text { (extinct } \\
\text { in Central } \\
\text { Asia, still } \\
\text { present in } \\
\text { Iran) }\end{array}$ \\
\hline & Capra & aegagrus & Wild Goat, Bezoar & VU \\
\hline & Gazella & subgutturosa & Goitered Gazelle & $\vee \cup$ \\
\hline & Marmota & menzbieri & Menzbier's Marmot & VU \\
\hline & Moschus & moschiferus & Siberian Musk Deer & $\vee \cup$ \\
\hline & Nyctalus & lasiopterus & Giant Noctule, Greater Noctule Bat & VU \\
\hline & Ovis & orientalis & $\begin{array}{l}\text { Mouflon, Cyprian Wild Sheep, Cyprus Mouflon, } \\
\text { Red Sheep, Urial }\end{array}$ & VU \\
\hline & Panthera & pardus & Leopard & $\vee \cup$ \\
\hline & Panthera & uncia & Snow Leopard, Ounce & VU \\
\hline & Vormela & peregusna & Marbled Polecat, European Marbled Polecat & VU \\
\hline
\end{tabular}




\begin{tabular}{|c|c|c|c|c|}
\hline Class & Genus & Species & Common names (Eng) & $\begin{array}{c}\text { Red List } \\
\text { status }\end{array}$ \\
\hline \multirow[t]{10}{*}{ Reptiles } & Alsophylax & laevis & Southern Even-fingered Gecko & CR \\
\hline & Alsophylax & tadjikiensis & Tajikistan Even-fingered Gecko & $\mathrm{CR}$ \\
\hline & Phrynocephalus & golubewii & & CR \\
\hline & Darevskia & kopetdaghica & & EN \\
\hline & Phrynocephalus & rossikowi & Uzbekistan Toadhead Agama & EN \\
\hline & Alsophylax & loricatus & Strauch's Even-fingered Gecko & VU \\
\hline & Alsophylax & szczerbaki & Szczerbak's Even-fingered Gecko & VU \\
\hline & Phrynocephalus & saidalievi & & VU \\
\hline & Phrynocephalus & strauchi & Strauch's Toad Agama & $\mathrm{VU}$ \\
\hline & Testudo & horsfieldii & $\begin{array}{l}\text { Afghan Tortoise, Central Asian Tortoise, Four- } \\
\text { toed Tortoise, Horsfield's Tortoise, Steppe } \\
\text { Tortoise }\end{array}$ & VU \\
\hline
\end{tabular}




\section{Annex 3}

Terrestrial threatened species (flora) ${ }^{136}$

(Source: IUCN Red List of Threatened Species website, accessed 15 April 2018)

\begin{tabular}{|c|c|c|c|}
\hline Genus & Species & Common names (Eng) & $\begin{array}{l}\text { Red } \\
\text { List } \\
\text { status }\end{array}$ \\
\hline Aldrovanda & vesiculosa & $\begin{array}{l}\text { Waterwheel, Common } \\
\text { Aldrovanda }\end{array}$ & EN \\
\hline Ammopiptanthus & nanus & & CR \\
\hline Amygdalus & ledebouriana & Wild Almond & EN \\
\hline Amygdalus & bucharica & Wild Almond & VU \\
\hline Armeniaca & vulgaris & Wild Apricot & EN \\
\hline Astragalus & bobrovii & & EN \\
\hline Atraphaxis & muschketowi & Shrubby Buckwheat & EN \\
\hline Berberis & karkaralensis & & CR \\
\hline Berberis & iliensis & & VU \\
\hline Betula & talassica & & EN \\
\hline Betula & tianschanica & & EN \\
\hline Calligonum & calcareum & & CR \\
\hline Calligonum & triste & & CR \\
\hline Calligonum & elegans & & EN \\
\hline Calligonum & matteianum & & EN \\
\hline Calligonum & molle & & EN \\
\hline Calligonum & paletzkianum & & VU \\
\hline Crataegus & darvasica & & CR \\
\hline Crataegus & knorringiana & & CR \\
\hline Crataegus & necopinata & & CR \\
\hline Damasonium & alisma & Starfruit & VU \\
\hline Lonicera & karataviensis & & CR \\
\hline Lonicera & paradoxa & & EN \\
\hline Malus & niedzwetzkyana & & EN \\
\hline Malus & sieversii & & VU \\
\hline Polygonum & toktogulicum & & $\mathrm{CR}$ \\
\hline Populus & berkarensis & & $\mathrm{CR}$ \\
\hline Prunus & tadzhikistanica & & EN \\
\hline
\end{tabular}

136 Except Least Concern species. 


\begin{tabular}{|l|l|l|c|}
\hline Genus & Species & Common names (Eng) & $\begin{array}{c}\text { Red } \\
\text { List } \\
\text { status }\end{array}$ \\
\hline Pyrus & korshinskyi & & CR \\
\hline Pyrus & tadshikistanica & & CR \\
\hline Pyrus & cajon & & EN \\
\hline Rhus & coriaria & Sumac, Elm-Leaved Sumac & VU \\
\hline Ribes & malvifolium & & CR \\
\hline Sibiraea & tianschanica & & CR \\
\hline Spiraeanthus & schrenkianus & & EN \\
\hline Swida & darvasica & & CR \\
\hline Zygophyllum & bucharicum & & CR \\
\hline Zygophyllum & darvasicum & & CR \\
\hline
\end{tabular}




\section{Annex 4}

\section{Important Bird Areas in Central Asia}

(Source: Birdlife International, 13 February 2019)

\begin{tabular}{|c|c|c|}
\hline Country & International Name & FinCode \\
\hline \multirow[t]{45}{*}{ Kazakhstan } & Kultansor and Tatysor Lakes & KZOO6O \\
\hline & Irgiz-Turgay Lakes & KZO42 \\
\hline & Sorbulak Lake System & KZOO97 \\
\hline & Zheltoranga & KZO94 \\
\hline & Naurzum State Nature Reserve & KZO4O \\
\hline & Syrdarya Delta Lakes & KZO44 \\
\hline & Kyzylkol Lake & KZO72 \\
\hline & Zharsor-Urkash Salt Lakes & KZO38 \\
\hline & Tortoise Islands & KZ117 \\
\hline & Tassuat Lake & KZO59 \\
\hline & Karasor Lake & KZOO88 \\
\hline & Zhusandala & KZO95 \\
\hline & Ili River Delta & KZOO92 \\
\hline & Vicinity of Korgalzhyn village & KZO54 \\
\hline & Aktubek & KZO57 \\
\hline & Amangeldy & KZO52 \\
\hline & Irtysh-Karaganda Waterworks 10 & KZO85 \\
\hline & Cherdoyak & KZ118 \\
\hline & Kamysh-Samarskie Lakes & KZOOO6 \\
\hline & Mugodzhary & KZO22 \\
\hline & Lower reaches of the Ashchyozek River & KZOO2 \\
\hline & Urda Sands & KZOO5 \\
\hline & North-western cliff faces of the Ustyurt Plateau & KZO18 \\
\hline & Western cliff faces of the Ustyurt Plateau & KZO14 \\
\hline & Korgalzhyn State Nature Reserve & KZO51 \\
\hline & Karakol Lake & KZO12 \\
\hline & Kaundy Depression & KZO16 \\
\hline & Basgurly-Zhazgurly Depression & KZO17 \\
\hline & Karagie Depression & KZO15 \\
\hline & Ashchykol and Barakkol Lakes & KZO61 \\
\hline & Balyktykol Lake & KZOB9 \\
\hline & Teke Lake & KZOBO \\
\hline & Korgankol Lake & KZO81 \\
\hline & Shcherbakty Lakes & KZ106 \\
\hline & Saumalkol Lake & KZOO87 \\
\hline & Shaglyteniz Lake and marshes & KZO48 \\
\hline & Karasuk & KZOO82 \\
\hline & Sarykopa Lake System & KZO41 \\
\hline & Western and northern foothills of the Kalba Range & KZ108 \\
\hline & Kulykol-Taldykol Lake System & KZO36 \\
\hline & Lakes in the lower reaches of the Chu River & KZOO69 \\
\hline & Kazakhstan portion of the river Volga's Delta - Zhambay & KZOOO \\
\hline & Delta of the Ural River & KZOOO \\
\hline & Tyulen'i (Seal) Islands & KZO11 \\
\hline & Topar Lake System & KZO93 \\
\hline
\end{tabular}


Akzhar Lakes

KZO71

Lesser Aral Sea

$\mathrm{KZO43}$

Donyz-Tau cliff faces

KZO19

Aktau cliff faces

Ulytau Mountains

KZO62

Cherniy (Black) Irtysh Delta

$\mathrm{KZ12O}$

Markakol State Nature Reserve

KZ119

Lower reaches of the Karatal River

KZO90

Ushkol Lake

Lower reaches of the Emba River

KZO91

Irtysh-Karaganda Waterworks 9

KZO1O

Alekseevskie steppe pine forests

KZO86

Iskrinskie Pine Forests

KZO49

Ereymentau Mountains

KZO83

Ortau upland massif

Ayak-Bestau Hills

KZO84

Western edge of the

KZO64

Karakoyin and Zhetikonyr Sands

$\mathrm{KZO} 63$

Middle reaches of the Sarysu River

206

Lower reaches of the Sarysu River

Koybagar-Tyuntyugur Lake System

KZO66

Shoshkaly Lake System

KZO33

Kushmurun Lake

Shalkar Lake

KZO27

Sarshyganak Lake

$\mathrm{KZO32}$

Teniz-Karakamys Lakes

KZOO1

Aksuat Lake

KZOO3

Bolshoy Kak Lake

$\mathrm{KZO} 23$

Sorbalyk-Maybalyk

$\mathrm{KZO} 28$

$\mathrm{KZO} 25$

Terenkol Lake

KZO45

Zhaltyr Lake

Balykty Lake

KZO3O

Maliy Kak Lake

KZO47

Telikol Lakes

KZO31

Amankaragay Forest

KZO68

Arkaly Mountains

KZO34

Karabas Mountains

KZ113

Ertis Ormany (Shaldai Forest)

$\mathrm{KZ112}$

Semey Ormany (Semipalatinsk Forest)

KZ105

Paradise Valley mountain plateau

KZ107

Zhagalbayly and Tuyemoynak Hills

$\mathrm{KZZ116}$

Eastern Kazakhstan uplands

$K Z 111$

Chingiztau Mountains

Kushum Lakes

Akzhan Lake

KZOO4

Sulukol Lake

KZO24

Kapchagay Canyon

KZO35

Uyalyshalkar Lake System

KZO96

Kumdykol-Zharlykol Lake System

KZO55

Tuzashchy and Karasor Lakes

KZO56

Zhumay-Mayshukyr Lake System

KZO58

Manyrak Mountains

KZO53

$\mathrm{KZZ12}$ 


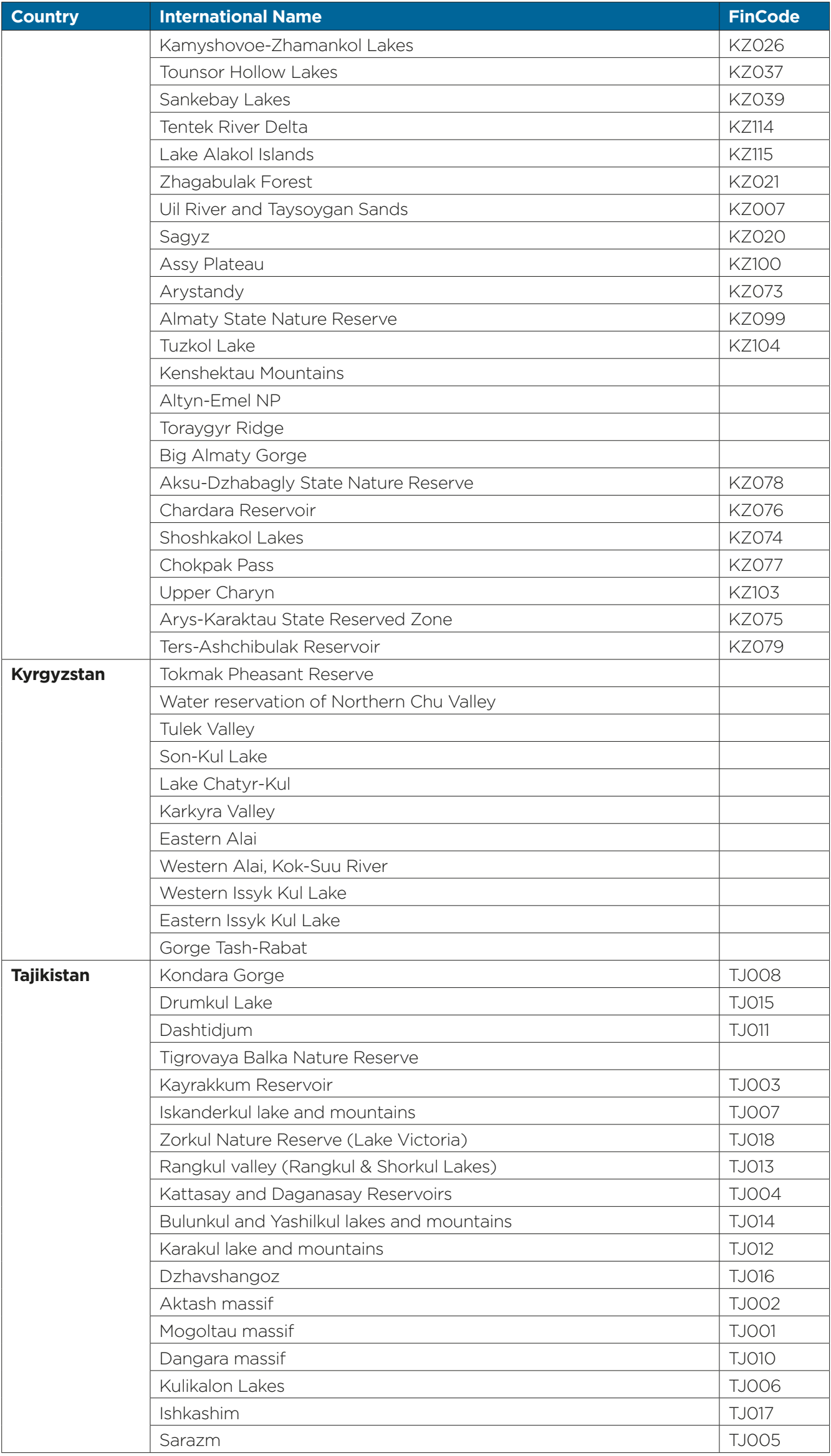




\begin{tabular}{|c|c|c|}
\hline Country & International Name & FinCode \\
\hline \multirow[t]{50}{*}{ Turkmenistan } & Garabogaz - Garshy & TMOO2 \\
\hline & Karabogaz & TMOO3 \\
\hline & South Cheleken Bay & TM005 \\
\hline & Garshy - Tarta & TMOO1 \\
\hline & Turkmenbashy Bay & TM006 \\
\hline & Turkmen Bay & TM007 \\
\hline & Garadashly - Ekerem & TM008 \\
\hline & Ekerem - Esenguly & TM009 \\
\hline & Sumbar & TMO2O \\
\hline & Dushakerekdag & TMO24 \\
\hline & Gurykhovudan & TMO29 \\
\hline & Kurtusuv - Khovudan & TMO27 \\
\hline & Goyungyrlan & TMO25 \\
\hline & Sarygamysh & TMO22 \\
\hline & Ayrakly - Garadzhaovlak & TM032 \\
\hline & Jarsay - Khangui & TM035 \\
\hline & Khankhovuz & TM036 \\
\hline & Repetek & TM045 \\
\hline & Erajy & TMO4O \\
\hline & Nargyz & $\mathrm{TMO} 43$ \\
\hline & Soltandag - Gyzylburun & TMO47 \\
\hline & Ersarybaba - Akkyr & TMO13 \\
\hline & Depmechay & \\
\hline & Akjagaya & TMO26 \\
\hline & Ketteshor - Ramankol & TMO44 \\
\hline & Zeyit - Kelif & TM048 \\
\hline & Garashor & $\mathrm{TMO} 21$ \\
\hline & Koymat - Begarslan & \\
\hline & Tekejik - Biynekyr & \\
\hline & Chokrak-Tutly & \\
\hline & Tejen & TM034 \\
\hline & Badhyz & TM038 \\
\hline & Garachop & TMO41 \\
\hline & Garabil & TMO46 \\
\hline & Uly Balkan & TM012 \\
\hline & Kurendag - Garagoz & TMO14 \\
\hline & Gorelde & TM039 \\
\hline & Muskinata & TMO33 \\
\hline & Uzboy & \\
\hline & Delili - Garajabatyr & TMO10 \\
\hline & Garadegish & TMO11 \\
\hline & Kopetdagkhovudan & TMO23 \\
\hline & Gurtli & TMO28 \\
\hline & Deryatakyr & TMO3O \\
\hline & Mergen & TMO31 \\
\hline & Saryyazy & TMO42 \\
\hline & Soltansanjar - Duyeboyun & TMO37 \\
\hline & Ogurjaly Island & TM004 \\
\hline & Tallymerjen & TM049 \\
\hline & Koytendag & \\
\hline
\end{tabular}




\begin{tabular}{|c|c|c|}
\hline Country & International Name & FinCode \\
\hline \multirow[t]{52}{*}{ Uzbekistan } & Mount Aktau & UZO1O \\
\hline & Aksay Lake and surrounding desert & UZOO7 \\
\hline & Achinskoe Lake & UZO22 \\
\hline & Aktepe Reservoir and Three Lakes & UZO48 \\
\hline & The desert around Kurkuduk village & UZOO5 \\
\hline & Saiga Nature Sanctuary & UZOO1 \\
\hline & Zekry Lake & UZO2O \\
\hline & Rogatoe Lake & UZOOB \\
\hline & Kagan Fish Farm & UZO16 \\
\hline & Vardanzi & UZO14 \\
\hline & Sudochye Lake & UZOO2 \\
\hline & Amudarya floodlands near Termez & UZO47 \\
\hline & Yuzhno-Surkhan (South-Surkhan) Reservoir & UZO46 \\
\hline & Dengizkul Lake & UZO21 \\
\hline & Tudakul and Kuymazar Reservoirs & UZO15 \\
\hline & Bukantau Mountain Range & UZOO6 \\
\hline & Zholdyrbas Lake & UZOO3 \\
\hline & Karnabchul Steppe & UZO18 \\
\hline & Karakyr Lakes & UZO12 \\
\hline & Dzheiran Ecocentre & UZO17 \\
\hline & Buzaubay & UZOOO9 \\
\hline & Khorezm Fish Farm and adjacent lakes & UZO11 \\
\hline & Khodzha-Davlet & UZO19 \\
\hline & Northern part of the Assake-Audan depression & UZOO4 \\
\hline & Akpetky Lakes and surrounding Aralkum Desert & UZO49 \\
\hline & Ayakaghytma Lake and surrounding desert & UZO51 \\
\hline & Sarykamysh Lake and surrounding Ustyurt Plateau & UZO50 \\
\hline & Mashankul and Khojakul Lake complex & UZO52 \\
\hline & Bashkyzylsay Unit of the Chatkal Mountains Biosphere Reserve & UZO28 \\
\hline & Angren Plateau & UZO27 \\
\hline & Nuratau Range & UZO37 \\
\hline & Tuzkan Lake & UZO35 \\
\hline & Central section of the Kurama Mountain Range & UZO33 \\
\hline & Chimkurgan Reservoir & UZO41 \\
\hline & Gissar State Nature Reserve & UZO42 \\
\hline & Kattakurgan Reservoir & UZO38 \\
\hline & Northern shore of Aydarkul Lake & UZO29 \\
\hline & Talimardzhan Reservoir & UZO23 \\
\hline & Oygaing River Valley & UZO24 \\
\hline & Dzhum-Dzhum & UZO4O \\
\hline & Balykchi Fish Farm & UZO31 \\
\hline & Arnasay Lake System & UZO30 \\
\hline & Dalverzin State Forestry and Hunting Management Area & UZO36 \\
\hline & Tuyabuguz Reservoir & UZO32 \\
\hline & Tereklisay section of the Chatkal Mountains Biosphere Reserve & UZO26 \\
\hline & Sarmysh Nature Park & UZO13 \\
\hline & Pulatkhan Gorge & UZO25 \\
\hline & Darasay Gorge & UZO45 \\
\hline & Mirzaaral Tugay & UZO34 \\
\hline & Middle reaches of the Sherabad River & UZO44 \\
\hline & South-west Gizzar Foothills & UZO43 \\
\hline & Zarafshan State Nature Reserve & UZO39 \\
\hline
\end{tabular}




\section{Annex 5}

\section{Areas having potential for key biodiversity areas}

in the mountain hotspot of Central Asia and overlapping with existing protected areas

(Source: adapted from CEPF, 2017)

\begin{tabular}{|c|c|c|c|c|}
\hline Country & KBA name & $\mathbf{K m}^{2}$ & $\begin{array}{l}\text { Global KBA } \\
\text { criteria met }\end{array}$ & Potential trigger species for criteria $(x)$ \\
\hline \multirow[t]{6}{*}{ Kazakhstan } & Karatau & 390 & B1 & $\begin{array}{l}\text { Dryopteris mindshelkensis, Aquilegia karatavica, Eremogone } \\
\text { turlanica, Populus berkarensis, Acantholimon inczevskii, } \\
\text { Arabis mindshilkensis, Stroganowia robusta, Oxytropis } \\
\text { echidna, Hedysarum karataviense, Hedysarum mindshilkense, } \\
\text { Eryngium karatavicum, Schrenkia kultiassovii, Prangos } \\
\text { equisetoides, Karatavia kultiassovii, Rubia pavlovii, } \\
\text { Dracocephalum karataviense, Cousinia mindshelkensis, } \\
\text { Saussurea mikeschinii, Rhaponticum karatavicum, } \\
\text { Tanacetopsis pjataevae, Tulipa alberti, Dracocephalum } \\
\text { karataviense, Pseudoeremostachus sewerzowii, [Vormela } \\
\text { peregusna], [Aquila nipalensis], [Aquila heliaca], [Neophron } \\
\text { percnopterus], [Falco cherrug], [Otis tarda], [Columba } \\
\text { eversmanni], [Streptopelia turtur], [Parnassius apollo], [Saga } \\
\text { pedo]* }\end{array}$ \\
\hline & Turkestan & 580 & B1 & $\begin{array}{l}\text { Botschantzevia karatavica, Cotoneaster karatavicus, } \\
\text { Cousinia grandifolia, Ferula leucographa, Fraxinus sogdiana, } \\
\text { Lepidolopha karatavica, Pseudosedum karatavicum, } \\
\text { Rhaphidophyton regelii, Rhaponticum karatavicum, } \\
\text { Scutellaria karatavica, Spiraeanthus schrenkianus, Stipa } \\
\text { karataviensis, Stroganowia robusta, Thesium minkvitzianum, } \\
\text { [Aquila heliaca], [Columba eversmanni], [Neophron } \\
\text { percnopterus], [Streptopelia turtur], [Testudo horsfieldii], } \\
\text { [Saga pedo], [Malus sieversii] }\end{array}$ \\
\hline & Ugam & 110 & $\mathrm{~A} 1, \mathrm{~B} 1$ & $\begin{array}{l}\text { Marmota menzbieri, Aconitum talassicum, Arabis popovii, } \\
\text { Allium lutescens, Bergenia ugamica, Betula talassica, } \\
\text { Lepidolopha karatavica, Oxytropis ugamica, Rhaphidophyton } \\
\text { regelii, [Panthera uncia], [Neophron percnopterus], [Falco } \\
\text { cherrug], [Streptopelia turtur], [Parnassius apollo], [Saga } \\
\text { pedo] }\end{array}$ \\
\hline & Tolebi & 170 & $\mathrm{~A} 1, \mathrm{~B} 1$ & $\begin{array}{l}\text { Marmota menzbieri, Stroganowia robusta, Ligularia } \\
\text { pavlovii, Stipa karataviensis, [Panthera uncia], [Neophron } \\
\text { percnopterus], [Falco cherrug], [Streptopelia turtur], } \\
\text { [Parnassius apollo], [Saga pedo] }\end{array}$ \\
\hline & Boraldai & 80 & B1 & $\begin{array}{l}\text { Rhaphidophyton regelii, Betula talassica, Lepidolopha } \\
\text { karatavica, Stroganowia robusta, Pseudosedum karatavicum, } \\
\text { Bergenia ugamica, Cotoneaster karatavicus, Oxytropis } \\
\text { talassica, Schrenkia kultiassovii, Rhaponticum karatavicum, } \\
\text { Karatavia kultiassovii, Ferula leucographa, Rubia pavlovii, } \\
\text { Fraxinus sogdiana, Scrophularia nuraniae, Dracocephalum } \\
\text { karataviense, Cousinia grandifolia, Ligularia pavlovii, Allium } \\
\text { lutescens, Pseudoeremostachus sewerzowii, Anaphalis } \\
\text { racemifera, [Vormela peregusna], [Aquila heliaca], [Falco } \\
\text { cherrug], [Neophron percnopterus], [Streptopelia turtur], } \\
\text { [Saga pedo], [Malus sieversii]] }\end{array}$ \\
\hline & Aksu-Zhabagly & 700 & B1 & $\begin{array}{l}\text { Lepidolopha karatavica, Dryopteris mindshelkensis, Malus } \\
\text { niedzwetzkyana, Rhaphidophyton regelii, Betula talassica, } \\
\text { Betula tianschanica, Oxytropis talassica, Schrenkia } \\
\text { kultiassovii, Karatavia kultiassovii, Lactuca mira, Cousinia } \\
\text { grandifolia, Trichanthemis aulieatensis, Iris alberti, Juno } \\
\text { kuschakewiczii, Tulipa alberti, Stipa karataviensis, Aconitum } \\
\text { talassicum, Anaphalis racemifera, [Panthera uncia], [Aquila } \\
\text { nipalensis], [Aquila heliaca], [Neophron percnopterus], } \\
\text { [Falco cherrug], [Streptopelia turtur], [Parnassius apollo], } \\
\text { [Saga pedo], [Malus sieversii], [Columba eversmanni] }\end{array}$ \\
\hline
\end{tabular}




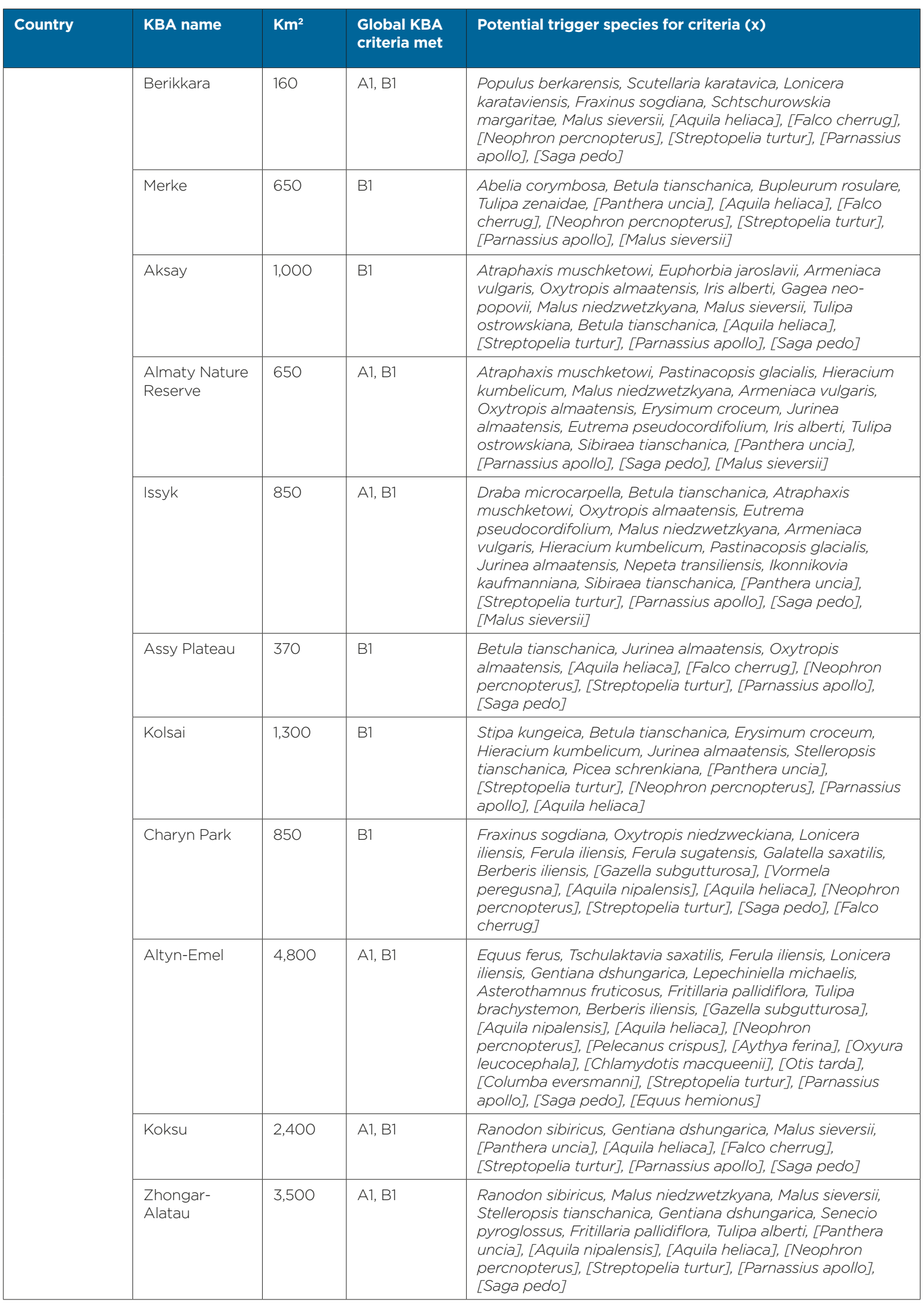




\begin{tabular}{|c|c|c|c|c|}
\hline Country & KBA name & $\mathrm{Km}^{2}$ & $\begin{array}{l}\text { Global KBA } \\
\text { criteria met }\end{array}$ & Potential trigger species for criteria $(x)$ \\
\hline \multirow[t]{10}{*}{ Kyrgyzstan } & Besh-Aral & 900 & $\mathrm{~A} 1, \mathrm{~B} 1$ & $\begin{array}{l}\text { Marmota menzbieri, Crataegus knorringiana, Crataegus } \\
\text { tianschanica, Juno zenaidae, Potentilla kamelinii, Thesium } \\
\text { minkwitzianum, Primula eugeniae, Tulipa kaufmanniana, Viola } \\
\text { allochroa, [Panthera uncia], [Aquila heliaca], [Falco cherrug], } \\
\text { [Betula tianschanica], [Malus niedzwetzkyana], [Malus } \\
\text { sieversii], [Pyrus korshinskyi] }\end{array}$ \\
\hline & Chandalash & 140 & B1 & $\begin{array}{l}\text { Astragalus sandalaschensis, Betula czatkalensis, Calophaca } \\
\text { pskemica, Hedysarum santalaschi, Psychrogeton adylovii, } \\
\text { Seseli tenellum, [Betula tianschanica], [Falco cherrug] }\end{array}$ \\
\hline & $\begin{array}{l}\text { Aflatun- } \\
\text { Padyshata }\end{array}$ & 600 & B1 & $\begin{array}{l}\text { Abies semenovii, Allium dodecadontum, Allium } \\
\text { viridiflorum, Androsace aflatunensis, Bunium sary-cheleki, } \\
\text { Bupleurum ferganense, Corydalis subverticillata, Elisanthe } \\
\text { fedtschenkoana, Ferula czatkalensis, Lathyrus dominianus, } \\
\text { Primula eugeniae, Pseudosedum ferganense, Silene fetissovii, } \\
\text { Malus niedzwetzkyana, Malus sieversii, [Panthera uncia] }\end{array}$ \\
\hline & Sary-Chalek & 200 & B1 & $\begin{array}{l}\text { Abies semenovii, Allium dodecadontum, Allium spathulatum, } \\
\text { Allium viridiflorum, Androsace aflatunensis, Bunium sary- } \\
\text { cheleki, Campanula eugeniae, Crataegus knorringiana, } \\
\text { Crataegus tianschanica, Elisanthe fedtschenkoana, } \\
\text { Exochorda tianschanica, Ferula czatkalensis, Ferula inciso- } \\
\text { serrata, Hedysarum chaitocarpum, Hyalolaena intermedia, } \\
\text { Leibnitzia knorringiana, Malus niedzwetzkyana, Malus } \\
\text { sieversii, Onosma brevipilosa, Oxytropis fedtschenkoana, } \\
\text { Oxytropis masarensis, Phlomoides urodonta, Pseudosedum } \\
\text { ferganense, Saxifraga vvedenskyi, Scutellaria knorringiae, } \\
\text { Scutellaria urticifolia, Scutellaria xanthosiphon, Seseli } \\
\text { giganteum, Silene eviscosa, Silene fetissovii, Tanacetopsis } \\
\text { ferganensis, Tulipa anadroma, [Panthera uncia] }\end{array}$ \\
\hline & Besh-Tash & 500 & B1 & $\begin{array}{l}\text { Abies semenovii, Bupleurum ferganense, Campanula } \\
\text { eugeniae, Cousinia margaritae, Draba sarycheleki, } \\
\text { Kosopoljanskia turkestanica, Neuroloma korovinii, Neuroloma } \\
\text { pulvinatum, Onosma trachycarpa, Pyrethrum sovetkinae, } \\
\text { Scutellaria popovii }\end{array}$ \\
\hline & Talas River & 20 & B1 & Leuciscus lindbergi, Dzihunia turdakovi, Triplophysa coniptera \\
\hline & Chychkan & 300 & $\mathrm{~A} 1, \mathrm{~B} 1$ & $\begin{array}{l}\text { Abies semenovii, Allium chychkanense, Cotoneaster } \\
\text { cinovskisii, Crataegus knorringiana, Draba sarycheleki, Juno } \\
\text { zenaida, Leibnitzia knorringiana, Salvia vvedenskyi, Seseli } \\
\text { korshinskyi, Silene sussamyrica }\end{array}$ \\
\hline & Dashman & 420 & B1 & $\begin{array}{l}\text { Acantholimon knorringianum, Astragalus irisuensis, } \\
\text { Campanula eugeniae, Chesneya quinata, Elisanthe } \\
\text { fedtschenkoana, Exochorda tianschanica, Hedysarum } \\
\text { chaitocarpum, Onosma brevipilosa, Oxytropis masarensis, } \\
\text { Pseudosedum ferganense, Primula eugeniae, Salvia } \\
\text { schmalhausenii, Scutellaria knorringiae, Scutellaria } \\
\text { xanthosiphon, Tanacetopsis ferganensis, [Pyrus korshinskyi] }\end{array}$ \\
\hline & Leilek & 660 & B1 & $\begin{array}{l}\text { Acantholimon strictiforme, Astragalus neobotschantzevii, } \\
\text { Seselopsis pusilla, Incarvillea olgae, Tulipa korolkowii, } \\
\text { Corydalis pseudoadunca }\end{array}$ \\
\hline & $\begin{array}{l}\text { Isfairam- } \\
\text { Shakhimardan }\end{array}$ & 2,200 & B1 & $\begin{array}{l}\text { Acantholimon langaricum, Astragalus khassanovii, } \\
\text { Bupleurum isphairamicum, Cousinia jassyensis, Crataegus } \\
\text { isfajramensis, Eremurus zenaidae, Ferula alaica, Ferula } \\
\text { subtilis, Incarvillea olgae, Nathaliella alaica, Neuroloma } \\
\text { botschantzevii, Neuroloma tianschanicum, Pedicularis } \\
\text { popovii, Phlomis drobovii, Phlomoides pulchra, Phlomoides } \\
\text { stellata, Physochlaina alaica, Saussurea schachimardanica, } \\
\text { Scutellaria nepetoides, Seseli alaicum, Semenovia alaica, } \\
\text { Stubendorffia botschantzevii, Stubendorffia curvinervia }\end{array}$ \\
\hline
\end{tabular}




\begin{tabular}{|c|c|c|c|c|}
\hline Country & KBA name & $\mathrm{Km}^{2}$ & $\begin{array}{l}\text { Global KBA } \\
\text { criteria met }\end{array}$ & Potential trigger species for criteria $(x)$ \\
\hline & Alai-Kuu & 1,650 & B1 & $\begin{array}{l}\text { Acantholimon karadarjense, Acanthophyllum coloratum, } \\
\text { Allium zergericum, Crataegus knorringiana, Hedysarum } \\
\text { chaitocarpum, Helichrysum ferganicum, Nepeta } \\
\text { pseudokokanica, Neuroloma tianschanicum, Olgaea } \\
\text { vedenskyi, Onosma azurea, Oxytropis masarensis, } \\
\text { Phlomoides cordifolia, [Panthera uncia] }\end{array}$ \\
\hline & $\begin{array}{l}\text { Chatyr-Kul } \\
\text { Lake }\end{array}$ & 220 & $\mathrm{~B} 1, \mathrm{D} 1$ & $\begin{array}{l}\text { Tadorna ferruginea, Tianschaniella umbellifera, [Falco } \\
\text { cherrug], Anser indicus }\end{array}$ \\
\hline & Son-Kul Lake & 320 & B1, D1 & $\begin{array}{l}\text { Tadorna ferruginea, Taraxacum syrtorum, [Falco cherrug], } \\
\text { [Aythya ferina] }\end{array}$ \\
\hline & $\begin{array}{l}\text { Kumtor and } \\
\text { Sarychat- } \\
\text { Ertash }\end{array}$ & 1,340 & $\mathrm{~A} 1, \mathrm{~B} 1$ & $\begin{array}{l}\text { Panthera uncia, Berberis kaschgarica, Saussurea involucrate, } \\
\text { Taraxacum syrtorum, [Falco cherrug] }\end{array}$ \\
\hline & Karkyra & 670 & $A 1, D 1$ & Sibiraea tianschanica, Anthropoides virgo \\
\hline & Sary-Djaz & 3,000 & $\mathrm{A1}, \mathrm{B} 1$ & $\begin{array}{l}\text { Panthera uncia, Asterothamnus schischkinii, Astragalus } \\
\text { dschangartensis, Artemisia saposhnikovii, Artemisia } \\
\text { nigricans, Chorispora insignis, Cuscuta syrtorum, Oxytropis } \\
\text { chantengriensis, Oxytropis piceetorum, Saussurea } \\
\text { involucrata, Saussurea kara-artscha, Seseli kaschgaricum, } \\
\text { Sibiraea tianschanica, Taraxacum syrtorum }\end{array}$ \\
\hline & $\begin{array}{l}\text { Eastern Issyk- } \\
\text { Kul Lakeshore }\end{array}$ & 680 & D1 & $\begin{array}{l}\text { Anthropoides virgo, Netta rufina, Tadorna ferruginea, [Otis } \\
\text { tarda], [Chlamydotis undulate], [Numenius tenuirostris] }\end{array}$ \\
\hline & $\begin{array}{l}\text { Western Issyk- } \\
\text { Kul } \\
\text { Lakeshore }\end{array}$ & 500 & $\mathrm{~B} 1, \mathrm{D} 1$ & $\begin{array}{l}\text { Netta rufina, Chesneya villosa, [Gavia arctica], [Vanellus } \\
\text { gregarius], [Aythya ferina] }\end{array}$ \\
\hline \multirow[t]{9}{*}{ Tajikistan } & Aktash & 120 & B1 & $\begin{array}{l}\text { Phrynocephalus strauchi, Ferula mogoltavica, [Falco } \\
\text { cherrug] }\end{array}$ \\
\hline & Ramit & 660 & B1 & $\begin{array}{l}\text { Dracocephalum formosum, Eremurus tadshikorum, Iris } \\
\text { hoogiana, Polygonum baldshuanicum, Thuja orientalis, } \\
\text { [Clanga clanga], [Falco cherrug], [Testudo horsfie/dii] }\end{array}$ \\
\hline & Sarikhadang & 180 & B1 & $\begin{array}{l}\text { Amygdalus bucharica, Cousinia splendida, Lagochilus } \\
\text { kschtutensis, Rhus coriaria, [Panthera uncia], [Falco cherrug], } \\
\text { [Malus sieversii], [Aquila nipalensis] }\end{array}$ \\
\hline & Shirkent & 80 & $A 1, B 1$ & $\begin{array}{l}\text { Amygdalus bucharica, Lonicera paradoxa, Rhus coriaria, } \\
\text { Juniperus semiglobosa, [Falco cherrug], [Neophron } \\
\text { percnopterus], [Testudo horsfieldii], [Malus sieversii] }\end{array}$ \\
\hline & $\begin{array}{l}\text { Tigrovaya } \\
\text { Balka }\end{array}$ & 620 & $\mathrm{~A} 1, \mathrm{~B} 1, \mathrm{D} 1$ & $\begin{array}{l}\text { Cervus hanglu, Netta rufina, Pseudoscaphirhynchus } \\
\text { kaufmanni, [Columba eversmanni], [Falco cherrug], } \\
\text { [Neophron percnopterus], [Aspiolucius esocinus] }\end{array}$ \\
\hline & Tajik Karatau & 600 & B1 & $\begin{array}{l}\text { Anemone bucharica, Ferula decurrens, Tulipa maximowiczii, } \\
\text { Tulipa rosea, Tulipa tubergeniana, [Testudo horsfieldii] }\end{array}$ \\
\hline & Kushvoristan & 830 & $A 1, B 1$ & $\begin{array}{l}\text { Amygdalus bucharica, Amygdalus vavilovii, Crataegus } \\
\text { darvasica, Ostrowskia magnifica, Rhus coriaria }\end{array}$ \\
\hline & Muminabad & 460 & B1 & $\begin{array}{l}\text { Arabidopsis bactriana, Crataegus necopinata, Ostrowskia } \\
\text { magnifica, Tulipa praestans, Iris hoogiana, Ranunculus } \\
\text { baldshuanicus, Pyrus tadshikistanica, [Malus sieversii] }\end{array}$ \\
\hline & Dashtijum & 400 & $\mathrm{~A} 1, \mathrm{~B} 1$ & $\begin{array}{l}\text { Amygdalus bucharica, Amygdalus vavilovii, Arabidopsis } \\
\text { bactriana, Ostrowskia magnifica, Swida darvasica, Ungernia } \\
\text { tadshikorum, Rhus coriaria, [Columba eversmanni], [Falco } \\
\text { cherrug] }\end{array}$ \\
\hline
\end{tabular}




\begin{tabular}{|c|c|c|c|c|}
\hline Country & KBA name & $\mathrm{Km}^{2}$ & $\begin{array}{l}\text { Global KBA } \\
\text { criteria met }\end{array}$ & Potential trigger species for criteria $(x)$ \\
\hline & Darvaz & 930 & $\mathrm{~A} 1, \mathrm{~B} 1$ & $\begin{array}{l}\text { Crataegus darvasica, Crataegus necopinata, Diospyros } \\
\text { lotus, Iris darvasica, Kudrjaschevia korshinskyi, Pyrus } \\
\text { tadshikistanica, Rhus coriaria, Tulipa anisophylla, Tulipa } \\
\text { linifolia, Ungernia tadshikorum, Zygophyllum, darvasicum, } \\
\text { [Falco cherrug] }\end{array}$ \\
\hline & Kamarou & 200 & B1 & $\begin{array}{l}\text { Lonicera heterotricha, Taraxacum srtizhoviae, Ungernia } \\
\text { tadshikorum, Aquila chrysaetos }\end{array}$ \\
\hline & $\begin{array}{l}\text { Zorkul } \\
\text { Mountains }\end{array}$ & 1,000 & $\mathrm{~B} 1, \mathrm{D} 1$ & $\begin{array}{l}\text { Tadorna ferruginea, Acantholimon alexeenkoanum, } \\
\text { Acantholimon varivtzevae, Artemisia kuschakewiczii, } \\
\text { Astragalus alexeenkoi, Desideria pamirica, Taraxacum } \\
\text { murgabicum, Taraxacum tzvelevii, [Panthera uncia], Anser } \\
\text { indicus, [Vanellus gregarius], Charadrius mongolus }\end{array}$ \\
\hline & Tajik NP & 23,000 & $\mathrm{~A} 1, \mathrm{~B} 1, \mathrm{D} 1$ & $\begin{array}{l}\text { Panthera uncia, Tadorna ferruginea, Arabidopsis } \\
\text { ovczinnikovii, Astragalus alexeenkoi, Clematis hilariae, } \\
\text { Desideria pamirica, Piptatherum purpurascens, Potentilla } \\
\text { borissi, Pulsatilla kostyczewii, [Clanga clanga], [Falco } \\
\text { cherrug], Anser indicus, [Aquila heliaca] }\end{array}$ \\
\hline \multirow[t]{2}{*}{ Turkmenistan } & Koytendag & 680 & B1 & $\begin{array}{l}\text { Astragalus aemulans, Astragalus kahiricus, Astragalus kelifi, } \\
\text { Astragalus kuhitangi, Astragalus leiosemius, Astragalus } \\
\text { plumbeus, Astragalus rubrigalli, Astragalus willisii, Artemisia } \\
\text { tenuisecta, Bunium kuhitangi, Carabus fedtschenkoi, } \\
\text { Chesneya tribuloides, Cleome gordjaginii, Cousinia bobrovii, } \\
\text { Cousinia dimoana, Cousinia glabriseta, Echinops multicaulis, } \\
\text { Echinops praetermissus, Haplophyllum vvedenskyi, } \\
\text { Hedysarum plumosum, Hymenocrater incisodentatus, } \\
\text { Jurinea tapetodes, Lagochilis nevskii, Lepidolopha } \\
\text { fedtschenkoana, Melanoides kainarensis, Melanotus } \\
\text { dolini, Onobrychis nikitinii, Oxytropis megalorrhyncha, } \\
\text { Pentanema parietarioides, Phlomis spinidens, Rosa bellicosa, } \\
\text { Scutellaria heterotricha, Scutellaria leptosiphon, Scutellaria } \\
\text { nevskii, Scutellaria squarrosa, Silene nevskii, Tanacetopsis } \\
\text { kraschenninikovii, Xylanthemum rupestre, Troglocobitis } \\
\text { starostini, [Falco cherrug], [Clanga clanga], [Streptopelia } \\
\text { turtur], [Panthera pardus] }\end{array}$ \\
\hline & $\begin{array}{l}\text { Zeyid } \\
\text { Reservoir and } \\
\text { Kelif Lakes }\end{array}$ & 780 & D1 & $\begin{array}{l}\text { Netta rufina, [Pelecanus crispus], Pelecanus onocrotalus, } \\
\text { Anas plathyrhynchos, [Aythya ferina], [Leucogeranus } \\
\text { eucogeranus] }\end{array}$ \\
\hline \multirow[t]{3}{*}{ Uzbekistan } & $\begin{array}{l}\text { Pskem River } \\
\text { Basin }\end{array}$ & 2,550 & $\mathrm{~A} 1, \mathrm{~B} 1$ & $\begin{array}{l}\text { Cottus jaxartensis, Glyptosternum reticulatum, Acantholimon } \\
\text { pskemense, Allium aflatunense, Allium pskemense, } \\
\text { Armeniaca vulgaris, Astragalus abolinii, Astragalus lasiocalyx, } \\
\text { Astragalus michaelis, Astragalus pskemensis, Bergenia } \\
\text { ugamica, Betula tianschanica, Cousinia dolichophylla, } \\
\text { Cousinia pterolepida, Dimorphosciadium gayoides, } \\
\text { Dracocephalum adylovii, Dracocephalum spinulosum, } \\
\text { Eremurus lactiflorus, Erysimum aksaricum, Hedysarum } \\
\text { drobovii, Jurinea mariae, Malus niedzwetzyana, Oxytropis } \\
\text { maidantalensis, Pseudoglossanthis simulans, Pyrus } \\
\text { asiae-mediae, Tulipa dasystemon, Tulipa dubia, Tulipa } \\
\text { dasystemonoides, Tulipa greigii, [Panthera uncia], [Neophron } \\
\text { percnopterus], [Malus sieversii] }\end{array}$ \\
\hline & $\begin{array}{l}\text { Karzhantau } \\
\text { Ridge }\end{array}$ & 150 & B1 & $\begin{array}{l}\text { Cousinia dolichophylla, Eremurus lactiflorus, Tulipa dubia, } \\
\text { Tulipa greigii }\end{array}$ \\
\hline & Chimgan & 200 & B1 & $\begin{array}{l}\text { Acantholimon ekatherinae, Astragalus abolinii, Astragalus } \\
\text { baranovii, Dracocephalum spinulosum, Eremurus lactiflorus, } \\
\text { Hedysarum drobovii, Nanophyton botschantzevii, } \\
\text { Oxytropis fedtschenkoi, Parrya tschimgamica, Phlomoides } \\
\text { tschimganica, Tulipa dubia, Tulipa greigii, [Malus sieversii] }\end{array}$ \\
\hline
\end{tabular}




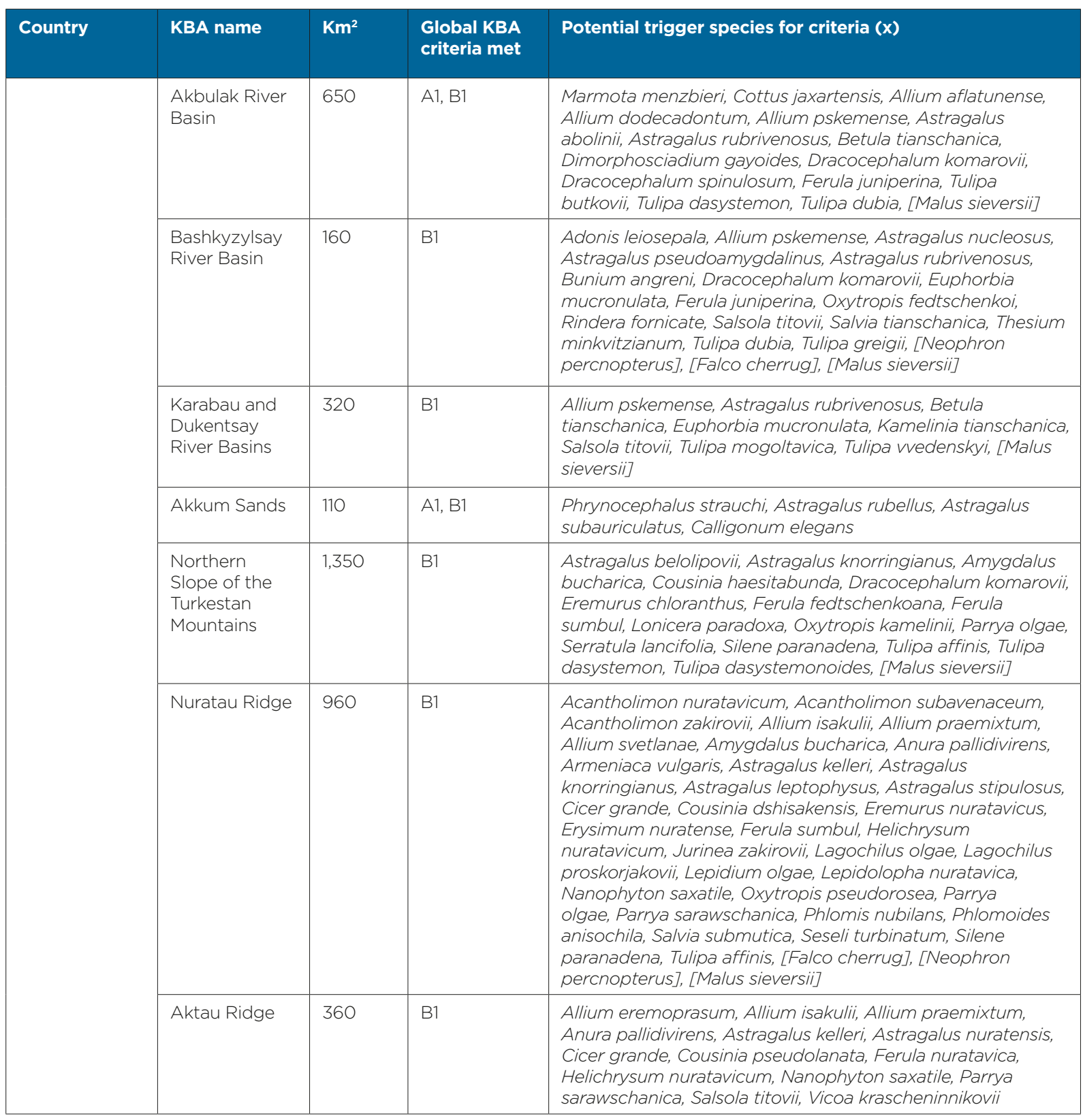




\begin{tabular}{|c|c|c|c|c|}
\hline Country & KBA name & $\mathrm{Km}^{2}$ & $\begin{array}{l}\text { Global KBA } \\
\text { criteria met }\end{array}$ & Potential trigger species for criteria $(x)$ \\
\hline & Western Hissar & 5,000 & $\mathrm{~A} 1, \mathrm{~B} 1$ & $\begin{array}{l}\text { Panthera uncia, Acantholimon annae, Acantholimon } \\
\text { gontscharovii, Acantholimon hissaricum, Acantholimon } \\
\text { taschkurganicum, Acantholimon vvedenskyi, Allium } \\
\text { brevidentiforme, Allium dolichomischum, Allium hexaceras, } \\
\text { Allium majus, Allium tytthanthum, Amygdalus bucharica, } \\
\text { Astomaea galiocarpa, Astragalus bobrovii, Astragalus } \\
\text { butkovii, Astragalus komarovii, Astragalus massagetowii, } \\
\text { Astragalus pseudanthylloides, Astragalus schutensis, } \\
\text { Astragalus stipulosus, Astragalus terrae-rubrae, Astragalus } \\
\text { tupalangi, Bergenia hissarica, Cephalopodum hissaricum, } \\
\text { Cicer incanum, Cousinia allolepis, Cousinia campyloraphis, } \\
\text { Cousinia subcandicans, Cousinia vvedenskyi, Dianthus } \\
\text { uzbekistanicus, Dimorphosciadium gayoides, Dionysia } \\
\text { hissarica, Dracocephalum formosum, Eremurus aitchisonii, } \\
\text { Eremurus iae, Eremurus pubescens, Erysimum nabijevii, } \\
\text { Euphorbia kudrjaschevii, Ferula fedtschenkoana, Ferula } \\
\text { pratovii, Ferula sumbul, Hedysarum bucharicum, Hedysarum } \\
\text { kudrjaschevii, Hedysarum magnificum, }\end{array}$ \\
\hline & $\begin{array}{l}\text { Western Hissar } \\
\text { (continued) }\end{array}$ & 5,000 & $\mathrm{~A} 1, \mathrm{~B} 1$ & $\begin{array}{l}\text { Iskandera hissarica, Jurinea asperifolia, Jurinea pjataevae, } \\
\text { Jurinea sangardensis, Lepidium minor, Ostrowskia } \\
\text { magnifica, Oxytropis lasiocarpa, Oxytropis microcarpa, } \\
\text { Oxytropis tyttantha, Parrya pjataevae, Pedicularis grandis, } \\
\text { Rhus coriaria, Ribes malvifolium, Saponaria gypsacea, } \\
\text { Scutellaria guttata, Scutellaria holosericea, Scutellaria } \\
\text { villosissima, Seseli merkulowiczii, Silene michelsonii, } \\
\text { Sphaerosciadium denaense, Tanacetopsis botschantzevii, } \\
\text { Thesium ramosissimum, Tulipa carinata, Tulipa ingens, Tulipa } \\
\text { lanata, Tulipa orythioides, Tulipa tubergeniana, Ungernia } \\
\text { victoris, Vvedenskia pinnatifolia, Zeravschania regeliana, } \\
\text { Xylanthemum rupestre, [Falco cherrug], [Neophron } \\
\text { percnopterus], [Malus sieversii] }\end{array}$ \\
\hline & $\begin{array}{l}\text { Kugitang and } \\
\text { Baysuntay } \\
\text { Ridges }\end{array}$ & 1,800 & B1 & $\begin{array}{l}\text { Glyptosternum reticulatum, Acantholimon butkovii, } \\
\text { Acantholimon majewianum, Allium decoratum, Allium } \\
\text { dolichomischum, Allium giganteum, Allium tytthanthum, } \\
\text { Amygdalus bucharica, Astragalus bobrovii, Astragalus } \\
\text { bucharicus, Astragalus juniperetorum, Astragalus plumbeus, } \\
\text { Astragalus pseudanthylloides, Astragalus rotundus, } \\
\text { Astragalus subschachimardanus, Astragalus terrae-rubrae, } \\
\text { Astragalus willisii, Calispepla aegacanthoides, Calophaca } \\
\text { reticulata, Cicer grande, Cleome tomentella, Cousinia } \\
\text { glabriseta, Cousinia glaphyrocephala, Cousinia gnezdilloi, } \\
\text { Cousinia haplophilla, Cousinia leptocladoides, Cousinia } \\
\text { platystegia, Cousinia rhodantha, Cousinia vvedenskyi, } \\
\text { Dionysia hissarica, Dracocephalum formosum, Eremurus } \\
\text { aitchisonii, Eremurus alberti, Eremurus baissunensis, } \\
\text { Eremurus iae, Eremurus pubescens, Eremurus suworowii, } \\
\text { Euphorbia densiuscula, Ferula tuberifera, Halothamnus } \\
\text { schurobi, Hedysarum bucharicum, Hedysarum magnificum, } \\
\text { Heliotropium bucharicum, Jurinea gracilis, Jurinea } \\
\text { sangardensis, Lepidium minor, Lepidolopha fedtschenkoana, } \\
\text { Otostegia bucharica, Oxytropis megalorrhyncha, Oxytropis } \\
\text { pseudoleptophysa, Oxytropis tyttantha, Oxytropis } \\
\text { vvedenskyi, Pyrus korshinskyi, Ribes malvifolium, } \\
\text { Salvia lilacinocaerulea, Scutellaria colpodea, Scutellaria } \\
\text { fedtschenkoi, Seseli nevskii, Silene nataliae, Spirostegia } \\
\text { bucharica, Tulipa carinata, Tulipa ingens, Tulipa lanata, Tulipa } \\
\text { orythioides, Tulipa tubergeniana, Xylanthemum rupestre, } \\
\text { [Neophron percnopterus], [Malus sieversii], [Ovis orientalis]* }\end{array}$ \\
\hline
\end{tabular}

* Square brackets indicate globally threatened species that are not confirmed to meet the threshold for any global KBA criterion 


\section{Annex 6}

\section{Areas having potential for Key Biodiversity Areas in the mountain hotspot of Central Asia and not overlapping with existing protected areas}

(Source: adapted from CEPF, 2017)

\begin{tabular}{|c|c|c|c|c|}
\hline Country & KBA name & $\mathrm{Km}^{2}$ & $\begin{array}{l}\text { Global KBA } \\
\text { criteria Met }\end{array}$ & \\
\hline \multirow[t]{6}{*}{ Kazakhstan } & Kyzylkol & 40 & A1, D1 & $\begin{array}{l}\text { Aythya ferina, Oxyura leucocephala, Pelecanus crispus, } \\
\text { Tadorna ferruginea, [Streptopelia turtur], [Saga pedo]* }\end{array}$ \\
\hline & Arystandy & 160 & A1 & $\begin{array}{l}\text { Otis tarda, [Aquila heliaca], [Streptopelia turtur], } \\
\text { [Vormela peregusna] }\end{array}$ \\
\hline & $\begin{array}{l}\text { Chakpak Pass } \\
\text { and Ters- } \\
\text { Ashchibulak } \\
\text { Reservoir }\end{array}$ & 130 & D1 & $\begin{array}{l}\text { Anthropoides virgo, Columba eversmanni, Tadorna } \\
\text { ferruginea, Tetrax tetrax, [Aquila nipalensis], [Neophron } \\
\text { percnopterus], [Falco cherrug], [Otis tarda], } \\
\text { [Streptopelia turtur] }\end{array}$ \\
\hline & Toraigyr & 1,500 & B1 & $\begin{array}{l}\text { Silene tianschanica, Ikonnikovia kaufmanniana, Jurinea } \\
\text { robusta, Oxytropis niedzweckiana, Ferula iliensis, Ferula } \\
\text { sugatensis, Heliotropium parvulum, Tanacetopsis } \\
\text { goloskokovii, Galatella saxatilis, Tulipa ostrowskiana, } \\
\text { [Gazella subgutturosa], [Vormela peregusna], [Falco } \\
\text { cherrug], [Neophron percnopterus], [Streptopelia } \\
\text { turtur], [Aquila nipalensis] }\end{array}$ \\
\hline & Narynkol & 1,000 & B1 & $\begin{array}{l}\text { Betula jarmolenkoana, Erysimum croceum, Stipa } \\
\text { kungeica, [Panthera uncia], [Aquila heliaca], } \\
\text { [Streptopelia turtur], [Parnassius apollo] }\end{array}$ \\
\hline & Tuzkol & 3 & D1 & $\begin{array}{l}\text { Tadorna ferruginea, [Falco cherrug], [Streptopelia } \\
\text { turtur] }\end{array}$ \\
\hline \multirow[t]{8}{*}{ Kyrgyzstan } & Sumsar & 20 & B1 & Acantholimon karabajeviorum, Primula eugeniae \\
\hline & Kassan-Sai & 750 & B1 & $\begin{array}{l}\text { Hyalolaena intermedia, Saussurea gorbunovae, } \\
\text { Seseli giganteum, [Neophron percnopterus], [Malus } \\
\text { niedzwetzkyana], [Malus sieversii], [Pyrus korshinskyi], } \\
\text { [Vormela peregusna] }\end{array}$ \\
\hline & Nyldy & 150 & B1 & $\begin{array}{l}\text { Allium dasyphyllum, Kosopoljanskia turkestanica, } \\
\text { Neuroloma pulvinatum, Tulipa talassica, [Betula } \\
\text { tianschanica] }\end{array}$ \\
\hline & $\begin{array}{l}\text { Torkent-Kara- } \\
\text { Jygach }\end{array}$ & 160 & B1 & $\begin{array}{l}\text { Polygonum toktogulicum, Pyrethrum sovetkinae, } \\
\text { Pyrethrum sussamyrense, Salvia vvedenskyi, Scutellaria } \\
\text { botvaevae }\end{array}$ \\
\hline & Sargata & 40 & B1 & $\begin{array}{l}\text { Phlomoides korovinii, Phlomoides milkoi, Tanacetopsis } \\
\text { korovinii }\end{array}$ \\
\hline & Karasu & 10 & B1 & $\begin{array}{l}\text { Acantholimon linczevskianum, Allium dodecadontum, } \\
\text { Allium formosum, Delphinium knorringianum, Festuca } \\
\text { tzveleviana, Phlomoides kurpsaica, Scutellaria } \\
\text { andrachnoides, Seseli galioides, Seseli korshinskyi, } \\
\text { Silene fetissovii, Silene neoladyginae }\end{array}$ \\
\hline & Kurp-Sai & 45 & B1 & $\begin{array}{l}\text { Cousinia abolinii, Phlomoides adylovii, Phlomoides } \\
\text { kurpsaica, Scutellaria andrachnoides, Silene fetissovii }\end{array}$ \\
\hline & Bekechal & 120 & B1 & $\begin{array}{l}\text { Allium bekeczalicum, Phlomoides kurpsaica, Pyrethrum } \\
\text { brachanthemoides }\end{array}$ \\
\hline
\end{tabular}




\begin{tabular}{|c|c|c|c|c|}
\hline Country & KBA name & $\mathrm{Km}^{2}$ & $\begin{array}{l}\text { Global KBA } \\
\text { criteria Met }\end{array}$ & \\
\hline & Kyzyl-Unur & 480 & B1 & $\begin{array}{l}\text { Astragalus irisuensis, Campanula eugeniae, Exochorda } \\
\text { tianschanica, Geranium sophiae, Hedysarum } \\
\text { chaitocarpum, Juno zenaidae, Onosma brevipilosa, } \\
\text { Oxytropis masarensis, Phlomoides adylovii, } \\
\text { Phlomoides cordifolia, Pseudosedum ferganense, } \\
\text { Salvia schmalhausenii, Scutellaria xanthosiphon, Silene } \\
\text { fetissovii, Seseli korshinskii, Ungernia ferganica, [Malus } \\
\text { niedzwetzkyana], [Malus sieversii], [Pyrus korshinskyi] }\end{array}$ \\
\hline & Bazar-Korgon & 240 & B1 & $\begin{array}{l}\text { Astragalus irisuensis, Astragalus kugartensis, } \\
\text { Delphinium ferganicum, Elisanthe fedtschenkoana, } \\
\text { Exochorda tianschanica, Hedysarum chaitocarpum, } \\
\text { Hylotelephium tianschanicum, Juno zenaidae, Oxytropis } \\
\text { masarensis, Phlomoides cordifolia, Pseudosedum } \\
\text { ferganense, Silene fetissovii, Ungernia ferganica, } \\
\text { Eminium regelii, Primula eugeniae, Viola allochroa }\end{array}$ \\
\hline & Tuz & 550 & B1 & $\begin{array}{l}\text { Draba alajica, Iskandera alaica, Littledalea alaica, } \\
\text { Paraquilegia scabrifolia, Pulsatilla kostyczewii, Rindera } \\
\text { alaica, [Betula tianschanica] }\end{array}$ \\
\hline & Alai Valley & 2,700 & B1 & $\begin{array}{l}\text { Acantholimon alaicum, Artemisia knorringiana, Draba } \\
\text { alajica, Hedysarum daraut-kurganicum, Iskandera } \\
\text { alaica, Littledalea alaica, Prangos gyrocarpa, Pulsatilla } \\
\text { kostyczewii, Sorbaria olgae, Gloydius rickmersi, Ellobius } \\
\text { alaicus, [Panthera uncia], [Falco cherrug] }\end{array}$ \\
\hline & Ak-Sai & 900 & B1 & $\begin{array}{l}\text { Allium semenovii, Taraxacum syrtorum, Anthropoides } \\
\text { virgo }\end{array}$ \\
\hline & $\begin{array}{l}\text { Kavak-Too and } \\
\text { Moldo-Too }\end{array}$ & 120 & B1 & $\begin{array}{l}\text { Acantholimon linczevskianum, Cousinia schischkinii, } \\
\text { Mogoltavia narynensis, Nepeta narynensis, Seseli } \\
\text { luteolum }\end{array}$ \\
\hline \multirow[t]{10}{*}{ Tajikistan } & Asht & 500 & B1 & $\begin{array}{l}\text { Amygdalus bucharica, Rhus coriaria, [Falco cherrug], } \\
\text { [Malus sieversii] }\end{array}$ \\
\hline & Kayrakkum & 1,000 & B1 & $\begin{array}{l}\text { Phrynocephalus helioscopus, Eremias scripta } \\
\text { pherganensis, Carex bucharica, Cousinia darwasica, } \\
\text { Cousinia leptocampyla, Lonicera paradoxa, [Columba } \\
\text { eversmanni], Anas platyrhynchos, Grus grus, } \\
\text { [Chlamydotis undulate], [Otis tarda] }\end{array}$ \\
\hline & $\begin{array}{l}\text { Turkestan } \\
\text { Mountains } \\
\text { Southern } \\
\text { Slope }\end{array}$ & 500 & B1 & $\begin{array}{l}\text { Iskandera hissarica, Lonicera paradoxa, [Neophron } \\
\text { percnopterus], [Malus sieversii], [Falco cherrug] }\end{array}$ \\
\hline & $\begin{array}{l}\text { Upper } \\
\text { Zeravshan }\end{array}$ & 330 & B1 & $\begin{array}{l}\text { Blanfordimys bucharensis, Carex bucharica, Cousinia } \\
\text { darwasica, Cousinia leptocampyla, Lonicera paradoxa, } \\
\text { Blanfordimys bucharensis, [Panthera uncia] }\end{array}$ \\
\hline & Yagnob & 20 & B1 & $\begin{array}{l}\text { Acantholimon komarovii, Iris hoogiana, Rochelia } \\
\text { claviculata, Roegneria carinata, [Falco cherrug], } \\
\text { [Neophron percnopterus], [Streptopelia turtur] }\end{array}$ \\
\hline & Upper Gissar & 300 & A1, B1 & $\begin{array}{l}\text { Amygdalus bucharica, Iskandera hissarica, [Panthera } \\
\text { uncia], [Malus sieversii] }\end{array}$ \\
\hline & Kondara & 10 & B1 & $\begin{array}{l}\text { Allium flavellum, Allium lipskyanum, Dracocephalum } \\
\text { formosum, Stubendorffia aptera, Thesium } \\
\text { gontscharovii, Tulipa praestans, Sorex buchariensis }\end{array}$ \\
\hline & Karnay & 80 & B1 & $\begin{array}{l}\text { Astragalus tashkutanus, Gagea holochiton, Gagea } \\
\text { villosula, Juniperus semiglobosa, Cousinia splendid } \\
\text { [Falco cherrug], [Neophron percnopterus] }\end{array}$ \\
\hline & Tajik Babatag & 850 & B1 & $\begin{array}{l}\text { Calligonum griseum, Gypsophila tadshikistanica, } \\
\text { Gypsophila vedeneevae, Stipa longiplumosa, Stipa } \\
\text { ovczinnikovii, Tulipa tubergeniana, Testudo horsfieldii, } \\
\text { [Neophron percnopterus] }\end{array}$ \\
\hline & Gazimalik & 700 & B1 & $\begin{array}{l}\text { Allium gypsodictyum, Anemone bucharica, Circaetus } \\
\text { ferox, Tulipa tubergeniana }\end{array}$ \\
\hline
\end{tabular}




\begin{tabular}{|c|c|c|c|c|}
\hline Country & KBA name & $\mathrm{Km}^{2}$ & $\begin{array}{l}\text { Global KBA } \\
\text { criteria Met }\end{array}$ & \\
\hline & Sarsaryak & 200 & B1 & $\begin{array}{l}\text { Salvia baldshuanica, Tulipa maximowiczii, Tulipa } \\
\text { subpraestans, [Testudo horsfieldii], [Haliaeetus } \\
\text { leucoryphus] }\end{array}$ \\
\hline & Ayvaj & 220 & A1, B1 & $\begin{array}{l}\text { Allium gypsodictyum, Alsophylax tadjikensis, } \\
\text { Pseudoscaphirhynchus kaufmanni, [Aspiolucius } \\
\text { esocinus], [Chlamydotis macqueenii] }\end{array}$ \\
\hline \multirow[t]{10}{*}{ Tajikistan } & Khojamumin & 30 & B1 & $\begin{array}{l}\text { Amygdalus bucharica, Crocus korolkowii, Ostrowskia } \\
\text { magnifica, Rhus coriaria }\end{array}$ \\
\hline & Baljuvan & 940 & A1, B1 & $\begin{array}{l}\text { Crataegus necopinata, Iris hoogiana, Pyrus cajon, Pyrus } \\
\text { tadshikistanica, Ranunculus baldshuanicus, Salvia } \\
\text { baldshuanica, Tulipa praestans, Malus sieversii }\end{array}$ \\
\hline & Tavildara & 3,000 & A1, B1 & $\begin{array}{l}\text { Iris darvasica, Iris hoogiana, Juno popovii, Juno } \\
\text { tadshikorum, Lonicera paradoxa, Rosa longisepala, } \\
\text { Panthera uncia }\end{array}$ \\
\hline & Vanj & 70 & A1, B1 & Nepeta badachschanica, Parnassius autocrator \\
\hline & Rushan & 50 & B1 & $\begin{array}{l}\text { Cicer garanicum, Cicer macracanthus, Hordeum } \\
\text { brevisubulatum, Triticum aestivum }\end{array}$ \\
\hline & Shakhdara & 30 & A1, B1 & Lonicera pamirica, Myrtama elegans, Pyrus korshinskyi \\
\hline & Kudara & 300 & B1 & $\begin{array}{l}\text { Artemisia kuschakewiczii, Cephalopodum } \\
\text { badachschanicum, Lonicera pamirica, Taraxacum } \\
\text { murgabicum, Taraxacum tzvelevii, [Falco cherrug], }\end{array}$ \\
\hline & Ishkashim & 35 & B1 & $\begin{array}{l}\text { Acrocephalus orinus, Cicer garanicum, Hordeum } \\
\text { brevisubulatum, Hordeum turkestanicum, riticum } \\
\text { aestivum, [Falco cherrug] }\end{array}$ \\
\hline & Alichur Valley & 65 & B1 & $\begin{array}{l}\text { Desideria pamirica, Myrtama elegans, Taraxacum } \\
\text { jaschilkuliense, [Falco cherrug] }\end{array}$ \\
\hline & Shorkul Lake & 650 & D1 & Tadorna ferruginea, Anser indicus, Charadrius mongolus \\
\hline Turkmenistan & Tallymerjen & 1,500 & D1 & $\begin{array}{l}\text { Grus grus, Tadorna ferruginea, Vanellus gregarius, } \\
\text { [Anser anser] }\end{array}$ \\
\hline \multirow[t]{6}{*}{ Uzbekistan } & $\begin{array}{l}\text { Angren } \\
\text { Plateau }\end{array}$ & 700 & A1, B1 & $\begin{array}{l}\text { Marmota menzbieri, Vormela peregusna, Adonis } \\
\text { leiosepala, Bunium angreni, Dimorphosciadium } \\
\text { gayoides, Dracocephalum komarovii, Ferula juniperina, } \\
\text { Hedysarum angrenicum, Hedysarum popovii, Oxytropis } \\
\text { fedtschenkoi, Parrya kuramensis, Parrya saxifraga, } \\
\text { Scutellaria angrenica, Tulipa dasystemon, Tulipa } \\
\text { dasystemonoides, Tulipa dubia, Tulipa vvedenskyi, } \\
\text { Helianthemum songaricum }\end{array}$ \\
\hline & $\begin{array}{l}\text { Northern } \\
\text { Slope of the } \\
\text { Kuramin Ridge }\end{array}$ & 680 & B1 & $\begin{array}{l}\text { Acantholimon laxiusculum, Acantholimon margaritae, } \\
\text { Allium praemixtum, Allium pskemense, Astragalus } \\
\text { dolonus, Astragalus nucleosus, Astragalus } \\
\text { pseudoamygdalinus, Bunium angreni, Cicer } \\
\text { mogoltavicum, Eremurus korovinii, Rindera fornicate, } \\
\text { Salsola titovii, Tulipa mogoltavica, Tulipa vvedenskyi, } \\
\text { [Falco cherrug], [Malus sieversii] }\end{array}$ \\
\hline & $\begin{array}{l}\text { Upper } \\
\text { Reaches of } \\
\text { Chadak and } \\
\text { Chorkesar } \\
\text { Rivers }\end{array}$ & 530 & B1 & $\begin{array}{l}\text { Acantholimon laxiusculum, Dracocephalum } \\
\text { komarovii, Euphorbia mucronulata, Kuramosciadum } \\
\text { corydaliifolium, Tulipa dasystemon, Tulipa } \\
\text { dasystemonoides, Tulipa dubia }\end{array}$ \\
\hline & Pap Foothills & 240 & B1 & $\begin{array}{l}\text { Allium haneltii, Allium isakulii, Allium kuramense, } \\
\text { Anthochlamys tianschanica, Astragalus } \\
\text { austroferganicus, Astragalus pseudodianthus, Dorema } \\
\text { microcarpum, Mogoltavia sewerzowii, Salsola drobovii, } \\
\text { Tulipa intermedia, Tulipa scharipovii }\end{array}$ \\
\hline & Karatag & 40 & B1 & $\begin{array}{l}\text { Acantholimon nabievii, Allium filidentiforme, Mogoltavia } \\
\text { sewerzowii }\end{array}$ \\
\hline & Ungor Tepa & 20 & B1 & $\begin{array}{l}\text { Allium filidentiforme, Allium tatyanae, Allium } \\
\text { viridiflorum, Tulipa ferganica }\end{array}$ \\
\hline
\end{tabular}




\begin{tabular}{|c|c|c|c|c|}
\hline Country & KBA name & $\mathrm{Km}^{2}$ & $\begin{array}{l}\text { Global KBA } \\
\text { criteria Met }\end{array}$ & \\
\hline & $\begin{array}{l}\text { Chartak } \\
\text { Foothills }\end{array}$ & 30 & B1 & $\begin{array}{l}\text { Acantholimon nabievii, Hedysarum gypsaceum, } \\
\text { Lamyropappus schakaptaricus, Mogoltavia sewerzowii }\end{array}$ \\
\hline & $\begin{array}{l}\text { Syr Darya } \\
\text { Upstream }\end{array}$ & 40 & B1 & Cottus spinulosus \\
\hline & $\begin{array}{l}\text { Teshiktash } \\
\text { Foothills }\end{array}$ & 270 & B1 & Salsola drobovii, Tulipa ferganica \\
\hline & $\begin{array}{l}\text { Chilustun and } \\
\text { Kyrtashtau } \\
\text { Mountains }\end{array}$ & 60 & B1 & $\begin{array}{l}\text { Allium alaicum, Astragalus rhacodes, Ferula vicaria, } \\
\text { Salsola drobovii, Tulipa ferganica }\end{array}$ \\
\hline & Shakhimardan & 40 & B1 & $\begin{array}{l}\text { Acantholimon katrantavicum, Acantholimon } \\
\text { muchamedshanovii, Acantholimon schachimardanicum, } \\
\text { Allium backhousianum, Allium isakulii, Allium } \\
\text { schachimardanicum, Astragalus auratus, Astragalus } \\
\text { borissianus, Astragalus dianthoides, Astragalus } \\
\text { rhacodes, Fergania polyantha, Fumariola turkestanica, } \\
\text { Iskandera alaica, Lepidium curvinervium, Lonicera } \\
\text { paradoxa, Salsola drobovii, Salvia margaritae, Tulipa } \\
\text { dasystemon, Tulipa ferganica }\end{array}$ \\
\hline & Sokh & 200 & B1 & $\begin{array}{l}\text { Astragalus auratus, Astragalus dianthoides, Calligonum } \\
\text { calcareum, Calligonum elegans, Ferula vicaria, Tulipa } \\
\text { ferganica }\end{array}$ \\
\hline & $\begin{array}{l}\text { Northern } \\
\text { Aydarkul }\end{array}$ & 1,400 & $A 1, D 1$ & Pelecanus crispus, Fulica atra, Microcarbo pygmaeus \\
\hline & Tuzkan Lake & 930 & A1, D1 & Pelecanus crispus, Tadorna ferruginea \\
\hline & $\begin{array}{l}\text { Northern } \\
\text { Piedmont } \\
\text { Plain of } \\
\text { Nuratau Ridge }\end{array}$ & 2,700 & B1 & $\begin{array}{l}\text { Allactaga vinogradovi, Astragalus kelleri, Tulipa } \\
\text { lehmanniana, [Testudo horsfieldii] }\end{array}$ \\
\hline & Koytash Ridge & 180 & B1 & $\begin{array}{l}\text { Acantholimon nuratavicum, Anura pallidivirens, } \\
\text { Astragalus kelleri, Astragalus knorringianus, Cousinia } \\
\text { dshisakensis, Erysimum nuratense, Helichrysum } \\
\text { nuratavicum, Seseli turbinatum, Tulipa affinis }\end{array}$ \\
\hline & $\begin{array}{l}\text { Kattakurgan } \\
\text { Reservoir }\end{array}$ & 130 & D1 & Anthropoides virgo \\
\hline & $\begin{array}{l}\text { Western } \\
\text { Zeravshan }\end{array}$ & 1,150 & B1 & $\begin{array}{l}\text { Astragalus chrysomallus, Astragalus stipulosus, } \\
\text { Amygdalus bucharica, Cerastium borisii, Cousinia } \\
\text { adenophora, Cousinia butkovii, Cousinia dshisakensis, } \\
\text { Dianthus uzbekistanicus, Ferula sumbul, Hedysarum } \\
\text { amankutanicum, Jurinea asperifolia, Komarovia } \\
\text { angiosperma, Lepidium minor, Oenanthe heterococca, } \\
\text { Oxytropis lipskyi, Parrya olgae, Salsola titovii, Serratula } \\
\text { lancifolia, Silene oreina, Silene popovii, Tulipa fosteriana, } \\
\text { Tulipa ingens, [Malus sieversii] }\end{array}$ \\
\hline & $\begin{array}{l}\text { Chimkurgan } \\
\text { Reservoir }\end{array}$ & 40 & D1 & Anser anser, Tadorna ferruginea \\
\hline & $\begin{array}{l}\text { Talimarjan } \\
\text { Reservoir }\end{array}$ & 780 & A1, D1 & Anser anser, Vanellus gregarius \\
\hline Uzbekistan & $\begin{array}{l}\text { Tarkapchigay } \\
\text { River Basin }\end{array}$ & 700 & $\mathrm{~B} 1$ & $\begin{array}{l}\text { Allium botschantzevii, Allium ophiophyllum, Crambe } \\
\text { gordjaginii, Eremurus suworowii, Eversmannia } \\
\text { botschantzevii, Hedysarum bucharicum, Hedysarum } \\
\text { magnificum, Heliotropium bucharicum, Jurinea } \\
\text { gracilis, Phlomoides gypsacea, Salsola lipschitzii, Salvia } \\
\text { lilacinocaerulea, Scutellaria colpodea, Spirostegia } \\
\text { bucharica, Tulipa uzbekistanica }\end{array}$ \\
\hline
\end{tabular}




\begin{tabular}{|c|c|c|c|c|}
\hline Country & KBA name & $\mathrm{Km}^{2}$ & $\begin{array}{l}\text { Global KBA } \\
\text { criteria Met }\end{array}$ & \\
\hline & $\begin{array}{l}\text { Kelif-Sherabad } \\
\text { Range }\end{array}$ & 950 & B1 & $\begin{array}{l}\text { Allium giganteum, Allium margaritiferum, Allium } \\
\text { ophiophyllum, Allium rhodanthum, Astragalus } \\
\text { alexeji, Astragalus rubrigalli, Chesneya tribuloides, } \\
\text { Cleome gordjaginii, Cleome tomentella, Cousinia } \\
\text { platystegia, Eremurus alberti, Eremurus baissunensis, } \\
\text { Euphorbia densiuscula, Hammada eriantha, } \\
\text { Heliotropium bucharicum, Phlomoides baburii, } \\
\text { Plocama botschantzevii, Spirostegia bucharica, Tulipa } \\
\text { tubergeniana, Zygophyllum bucharicum }\end{array}$ \\
\hline & Khaudaktau & 440 & B1 & $\begin{array}{l}\text { Allium ophiophyllum, Allium rhodanthum, Climacoptera } \\
\text { oxyphylla, Dipcadi turkestanicum, Euphorbia triodonta }\end{array}$ \\
\hline & $\begin{array}{l}\text { Uzbek } \\
\text { Babatag }\end{array}$ & 980 & B1 & $\begin{array}{l}\text { Allium giganteum, Allium gypsodictyum, Allium } \\
\text { margaritiferum, Allium sulphureum, Amygdalus } \\
\text { bucharica, Astragalus bucharicus, Astragalus } \\
\text { pseudoeremophysa, Astragalus pseudorhacodes, } \\
\text { Cousinia candicans, Cousinia stricta, Echinops } \\
\text { babatagensis, Echinops brevipenicillatus, Eremurus } \\
\text { alberti, Halothamnus babatagi, Lagochilus } \\
\text { botschantzevii, Oxytropis babatagi, Reaumuria } \\
\text { babataghi, Salvia insignis, Scutellaria colpodea, Tulipa } \\
\text { lanata, Tulipa tubergeniana, [Neophron percnopterus], } \\
\text { [Panthera pardus] }\end{array}$ \\
\hline
\end{tabular}

* Square brackets indicate globally threatened species not confirmed to meet the threshold for any global KBA criterion 


\section{Annex 7}

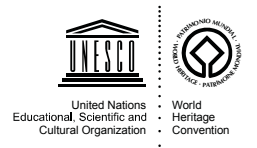

TENTATIVE LIST SUBMISSION FORMAT

\section{STATE PARTY:}

\section{DATE OF SUBMISSION:}

Submission prepared by:

Name:

E-mail:

Address:

Fax:

Institution:

Telephone:

Name of Property:

State, Province or Region:

Latitude and Longitude, or UTM coordinates:

\section{DESCRIPTION:}

Justification of Outstanding Universal Value:

(Preliminary identification of the values of the property which merit inscription on the World Heritage List)

Criteria met [see Paragraph 77 of the Operational Guidelines]:

(Please tick the box corresponding to the proposed criteria and justify the use of each below)

(i)

$$
\text { (ii) }
$$
(iv)

$$
\text { (v) }
$$$$
\text { (vi) }
$$$$
\text { (vii) }
$$$$
\text { (viii) }
$$$$
\text { (ix) }
$$

Statements of authenticity and/or integrity [see Paragraphs 78-95 of the Operational Guidelines]:

Comparison with other similar properties:

(The comparison should outline similarities with other properties on the World Heritage List or not, and the reasons that make the property stand out) 


\section{Annex 8}

TENTATIVE LIST SUBMISSION FORMAT
FOR TRANSNATIONAL AND TRANSBOUNDARY
FUTURE NOMINATIONS

\section{STATE PARTY:}

\section{DATE OF SUBMISSION:}

Submission ${ }^{14}$ prepared by:

Name:

E-mail:

Title:

Address:

Fax:

Institution:

Telephone:

1.a Name of the transnational / transboundary future nomination ${ }^{15}$ :

1.b Other States Parties participating:

1.c Name(s) of the national component part(s):

1.d State, Province or Region:

1.e Latitude and Longitude, or Universal Transverse Mercator (UTM) coordinates:

2.a Brief Description of the transnational / transboundary future nomination ${ }^{16}$ :

2.b Description of the component part(s):

3. JUSTIFICATION FOR OUTSTANDING UNIVERSAL VALUE ${ }^{17}$ OF THE FUTURE NOMINATION AS A WHOLE

(Preliminary identification of the values of the future nomination as a whole which merit inscription on the World Heritage List)

3.a Criteria met ${ }^{18}$ [see Paragraph 77 of the Operational Guidelines]:

(Please tick the box corresponding to the proposed criteria and justify the use of each below)

(i)

(ii)

(iii)

(iv)

(v)

(vi)

(vii)

(viii)

(ix)

$(\mathrm{x})$

14 This submission will be valid only when all the States Parties indicated in Section $1 . b$ have sent their submissions.
${ }^{15}$ The text provided in this section should be identical in all submissions of the States Parties involved in the presentation of the same
transnational / transboundary future nomination.
${ }^{16}$ In case of transnational/transboundary properties any modification will need the agreement of all States Parties concerned.
${ }^{17}$ In case of transnational/transboundary properties any modification will need the agreement of all States Parties concerned.
${ }^{18}$ In case of transnational/transboundary properties any modification will need the agreement of all States Parties concerned.

3.b Statements of authenticity and/or integrity [see Paragraphs 79-95 of the Operational Guidelines]:

3.c.l Justification of the selection of the component part(s) in relation to the future nomination as a whole:

3.c.2 Comparison with other similar properties ${ }^{19}$ :

(This comparison should outline the similarities with other properties inscribed or not on the World Heritage List, and the reasons for the exceptional character of the future nomination). 




\section{IUCN}

\section{$\longrightarrow$}

INTERNATIONAL UNION FOR CONSERVATION OF NATURE

REGIONAL OFFICE FOR EASTERN EUROPE AND CENTRAL ASIA

Dr Ivana Ribara 91

11070 Belgrade, Serbia

Tel +381 112272411

ecaro@iucn.org

www.iucn.org

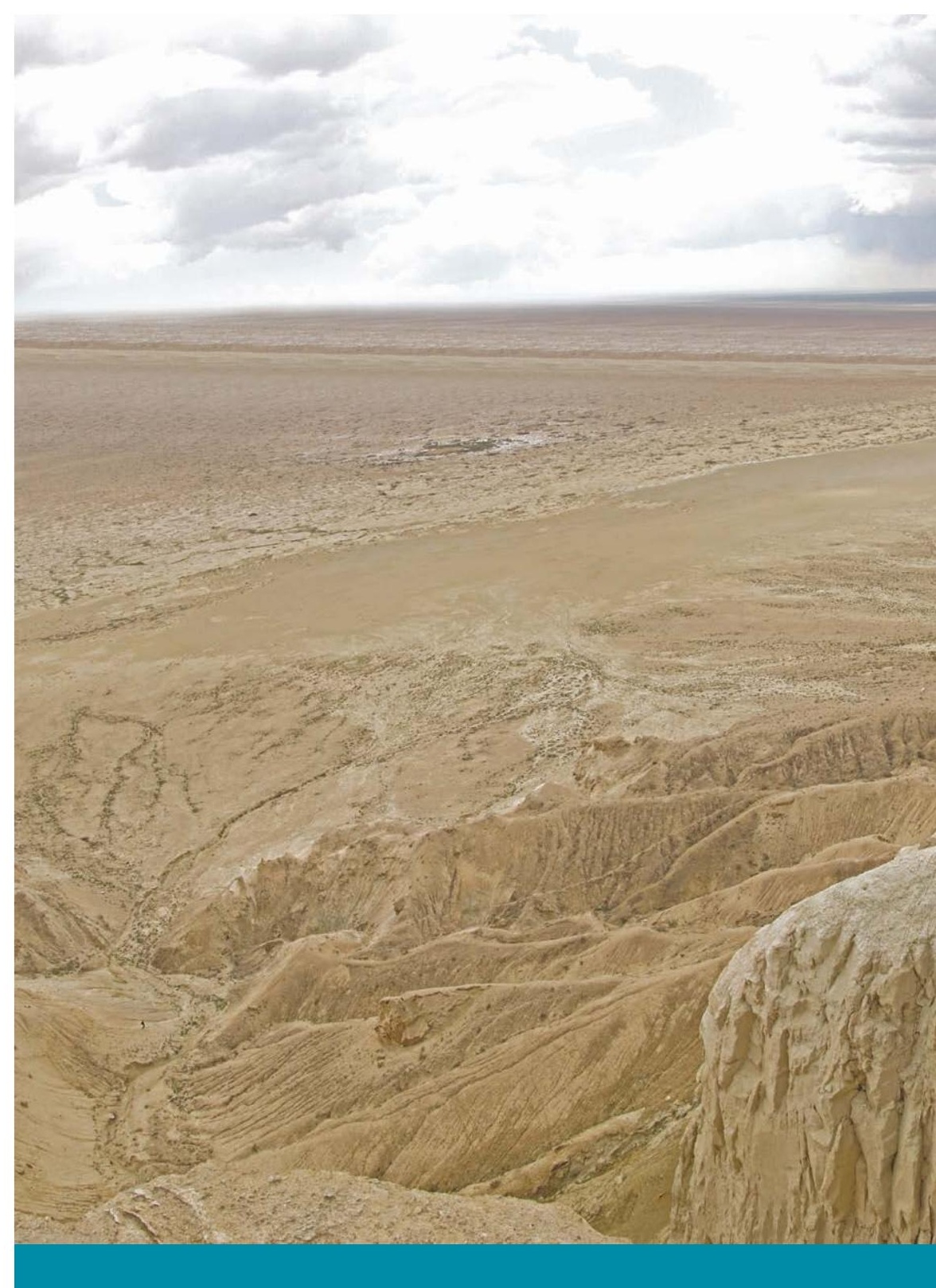

